\title{
A global model simulation of present and future nitrate aerosols and their direct radiative forcing of climate
}

\author{
D. A. Hauglustaine ${ }^{1}$, Y. Balkanski ${ }^{1}$, and M. Schulz ${ }^{2}$ \\ ${ }^{1}$ Laboratoire des Sciences du Climat et de l'Environnement (LSCE), UMR8212, CEA-CNRS-UVSQ, Gif-sur-Yvette, France \\ ${ }^{2}$ Norwegian Meteorological Institute, Blindern, Norway \\ Correspondence to: D. A. Hauglustaine (didier.hauglustaine@1sce.ipsl.fr)
}

Received: 21 January 2014 - Published in Atmos. Chem. Phys. Discuss.: 14 March 2014

Revised: 21 August 2014 - Accepted: 5 September 2014 - Published: 21 October 2014

\begin{abstract}
The ammonia cycle and nitrate particle formation are introduced into the LMDz-INCA (Laboratoire de Météorologie Dynamique, version 4 - INteraction with Chemistry and Aerosols, version 3) global model. An important aspect of this new model is that both fine nitrate particle formation in the accumulation mode and coarse nitrate forming on existing dust and sea-salt particles are considered. The model simulates distributions of nitrates and related species in agreement with previous studies and observations. The calculated present-day total nitrate direct radiative forcing since the pre-industrial is $-0.056 \mathrm{~W} \mathrm{~m}^{-2}$. This forcing corresponds to $18 \%$ of the sulfate forcing. Fine particles largely dominate the nitrate forcing, representing close to $90 \%$ of this value. The model has been used to investigate the future changes in nitrates and direct radiative forcing of climate based on snapshot simulations for the four representative concentration pathway (RCP) scenarios and for the 2030, 2050, and 2100 time horizons. Due to a decrease in fossil fuel emissions in the future, the concentration of most of the species involved in the nitrate-ammonium-sulfate system drop by 2100 except for ammonia, which originates from agricultural practices and for which emissions significantly increase in the future. Despite the decrease of nitrate surface levels in Europe and North America, the global burden of accumulation mode nitrates increases by up to a factor of 2.6 in 2100. This increase in ammonium nitrate in the future arises despite decreasing $\mathrm{NO}_{\mathrm{x}}$ emissions due to increased availability of ammonia to form ammonium nitrate. The total aerosol direct forcing decreases from its present-day value of $-0.234 \mathrm{~W} \mathrm{~m}^{-2}$ to a range of -0.070 to $-0.130 \mathrm{~W} \mathrm{~m}^{-2}$ in 2100 based on the considered scenario. The direct forcing decreases for all aerosols except for nitrates, for which
\end{abstract}

the direct negative forcing increases to a range of -0.060 to $-0.115 \mathrm{~W} \mathrm{~m}^{-2}$ in 2100 . Including nitrates in the radiative forcing calculations increases the total direct forcing of aerosols by a factor of 1.3 in 2000, by a factor of $1.7-2.6$ in 2030 , by $1.9-4.8$ in 2050 , and by $6.4-8.6$ in 2100 . These results show that the agricultural emissions of ammonia will play a key role in the future mitigation of climate change, with nitrates becoming the dominant contributor to the anthropogenic aerosol optical depth during the second half of the 21 st century and significantly increasing the calculated aerosol direct forcing. This significant increase in the influence that nitrate exerts on climate in the future will at the same time affect regional air quality and nitrogen deposition to the ecosystem.

\section{Introduction}

The formation of ammonium nitrate particles in the atmosphere is a secondary process initiated by the oxidation of $\mathrm{NO}_{2}$ to nitric acid $\left(\mathrm{HNO}_{3}\right)$ and by its further reaction with ammonia $\left(\mathrm{NH}_{3}\right) . \mathrm{HNO}_{3}$ can also be absorbed onto existing particulate matter to form coarse nitrate aerosols ( $\mathrm{Li}$ and Shao, 2009). Nitrogen oxide emissions are mostly associated with fossil fuel combustion (40\%), land use practices (15\%), and soil emissions (10\%) (Olivier et al., 1998). In contrast, global ammonia emissions into the atmosphere are dominated by agricultural practices (Bouwman et al., 1997). In western Europe and in the United States, as much as 90$100 \%$ of $\mathrm{NH}_{3}$ emissions result from animal and crop agriculture (Sutton et al., 2000; Hertel et al., 2011). In the atmosphere, $\mathrm{NH}_{3}$ reacts not only with $\mathrm{HNO}_{3}$ but also with other 
acidic gases such as $\mathrm{H}_{2} \mathrm{SO}_{4}$ to form ammonium $\left(\mathrm{NH}_{4}^{+}\right)$containing particles. Atmospheric nitrate particles have an adverse impact on health. In Europe, for instance, these particles account today for about $10-20 \%$ of the total dry aerosol mass (Putaud et al., 2004a; Schaap et al., 2004). These particles also contribute to the deposition of nitrogen to the surface, with a cascade of adverse effects on terrestrial and aquatic ecosystems and possible consequences for the global carbon cycle (Gruber and Galloway, 2008). Moreover, nitrate particles have the potential to directly affect the earth's radiation budget by reflecting solar radiation and climate through their effect on cloud formation and precipitation (Forster et al., 2007).

Several global models have been used to simulate the nitrate-ammonium-sulfate aerosol system and their impact on the present-day climate (e.g., van Dorland et al., 1997; Adams et al., 2001; Jacobson, 2001; Martin et al., 2004; Liao and Seinfeld, 2005; Myhre et al., 2006; Bauer et al., 2007; Bellouin et al., 2011; Xu and Penner, 2012). These earlier studies have reported direct radiative forcings ranging from -0.02 to $-0.19 \mathrm{~W} \mathrm{~m}^{-2}$. The uncertainty on the nitrate particle radiative forcing of climate remains high. Recently, Myhre et al. (2013) compiled the nitrate forcings calculated in the framework of AeroCom phase II by eight global models and derived a present-day direct radiative forcing for the most recent model versions ranging from -0.03 to $-0.17 \mathrm{~W} \mathrm{~m}^{-2}$ and a mean of $-0.10 \pm 0.04 \mathrm{~W} \mathrm{~m}^{-2}$. For the Atmospheric Chemistry and Climate Model Intercomparison Project (ACCMIP) historical simulations, Shindell et al. (2013) derived a direct forcing for nitrates ranging from $-0.03 \mathrm{~W} \mathrm{~m}^{-2}$ to $-0.41 \mathrm{~W} \mathrm{~m}^{-2}$, with a mean of $-0.19 \pm 0.18 \mathrm{~W} \mathrm{~m}^{-2}$. Fewer studies have assessed the future radiative forcing of nitrate particles. Adams et al. (2001), Liao and Seinfeld (2005), and Liao et al. (2009) investigated the future evolution of nitrates under the Special Report on Emissions Scenarios (SRES) A2 and derived a direct anthropogenic radiative forcing reaching -0.95 to $-1.28 \mathrm{~W} \mathrm{~m}^{-2}$ in 2100. Bauer et al. (2007) also investigated the evolution of nitrates in 2030 with the Goddard Institute for Space Studies (GISS) model following the SRES A1B emission scenario and calculated a steady increase in the nitrate negative forcing from $-0.5 \mathrm{~W} \mathrm{~m}^{-2}$ during the pre-industrial to $-0.11 \mathrm{~W} \mathrm{~m}^{-2}$ for the present and to $-0.14 \mathrm{~W} \mathrm{~m}^{-2}$ in 2030 . All these studies pointed out the steady increase of nitrate aerosols since industrialization and the associated direct radiative forcing of climate. They also suggest that the decreased radiative forcing from sulfates particles in the future associated with reduced emissions of $\mathrm{SO}_{2}$ could be partially offset by the increased nitrate forcing since the formation of ammonium nitrates is favored at lower sulfate loadings. More recently Bellouin et al. (2011) included nitrate aerosols in their future Coupled Model Intercomparison Project (CMIP) 5 simulations driven by the representative concentration pathway (RCP) scenarios and indicated that nitrates could become an important aerosol species in the fu- ture, making the aerosol radiative forcing 2-4 times stronger by 2100 (in their study the nitrate forcing increases from $-0.2 \mathrm{~W} \mathrm{~m}^{-2}$ in 2000 to $-0.6,-0.4,-0.5$ and $-0.7 \mathrm{~W} \mathrm{~m}^{-2}$ by 2090 in scenarios RCP2.5, RCP4.5, RCP6.0 and RCP8.5, respectively).

In this paper, the atmospheric ammonia cycle and nitrate particle formation are introduced into the LMDz-INCA global three-dimensional climate-chemistry model. Numerous detailed models have been developed in order to treat the partitioning of nitrate and ammonium between the gas phase and the aerosol phase assuming thermodynamical equilibrium between phases (e.g., Pilinis and Seinfeld, 1987; Zhang et al., 2000; Metzger et al., 2002a; Metzger et al., 2006) or treating the dynamical mass transfer between each aerosol size bin explicitly (e.g., Pilinis et al., 2000; Jacobson, 1999; Sun and Wexler, 1998; Lauer et al., 2005). In order to apply these computationally expensive models at the global scale, several authors have chosen to apply parameterizations for the relationships between activity coefficients and relative humidity (Metzger et al., 2002a, b; Myhre et al., 2006; Bauer et al., 2007; Pringle et al., 2010) or to use a hybrid dynamic method (Feng and Penner, 2007; Xu and Penner, 2012). In this study, since the LMDz-INCA general circulation model is designed for long-term simulations, we also use a simplified approach, and the phase equilibrium of the ammoniumsulfate-nitrate aerosol system is introduced for fine particles based on the simple thermodynamical formulation used initially in regional acid deposition chemical transport models (Hov et al., 1988; Ackermann et al., 1995), in global chemical transport models (Tie et al., 2005) and more recently in an earth system model (Bellouin et al., 2011). In addition to this formation of fine nitrate particles in the accumulation mode, the role of nitric acid uptake on mineral dust and sea-salt particles to form coated coarse nitrate particles can also play an important role in the total nitrate and nitric acid budget in the atmosphere and hence on the radiative forcing (e.g., Liao and Seinfeld, 2005; Myhre et al., 2006; Bauer et al., 2007; Feng and Penner, 2007; Xu and Penner, 2012). The formation of coarse nitrate particles on dust and on sea-salt particles is introduced into LMDz-INCA, adopting a firstorder irreversible removal. This method is computationally efficient and has often been used in global models (e.g., Dentener and Crutzen, 1993; Bauer et al., 2004, 2007; Evans et al., 2005; Fairlie et al., 2010) despite the fact that limitations for this formulation exist (Feng and Penner, 2007). An evaluation of the simulated aerosol distributions calculated with the LMDz-INCA model and of the optical depth and surface nitrate and sulfate depositions are performed. Based on the recent RCP CMIP5 emission scenarios, we then use the model to calculate the present-day and future anthropogenic direct radiative forcing of fine and coarse nitrate particles and to assess the relative contribution of nitrates to the aerosol optical depth and radiative forcing.

The three-dimensional global model used in this study and the extension of the chemical and aerosol scheme to include 
ammonia and nitrate particles are described in Sect. 2 . Section 3 presents the present-day global distributions of aerosols, the evaluation of the model results and the direct radiative forcing of aerosols. The results of the future simulations in terms of atmospheric composition, surface deposition and direct radiative forcing of climate are presented in Sect. 4. Finally, Sect. 5 gives the summary and conclusions.

\section{Model description}

\subsection{The LMDz-INCA model}

We use the LMDz-INCA global chemistry-aerosolclimate model coupling online the LMDz (Laboratoire de Météorologie Dynamique, version 4) general circulation model (Hourdin et al., 2006) and the INCA (INteraction with Chemistry and Aerosols, version 3) model (Hauglustaine et al., 2004). The interaction between the atmosphere and land surface is ensured through the coupling of $\mathrm{LMDz}$ with the ORCHIDEE (ORganizing Carbon and Hydrology In Dynamic Ecosystems, version 9) dynamical vegetation model (Krinner et al., 2005). In the present configuration, the model includes 19 hybrid vertical levels extending up to $4 \mathrm{hPa}$. This corresponds to a vertical resolution of about $300-500 \mathrm{~m}$ in the planetary boundary layer (first level at $70 \mathrm{~m}$ height) and to a resolution of about $2 \mathrm{~km}$ at the tropopause (with 7-9 levels located in the stratosphere). The horizontal resolution is $1.9^{\circ}$ in latitude and $3.75^{\circ}$ in longitude. The primitive equations in the general circulation model (GCM) are solved with a 3 min time step, large-scale transport of tracers is carried out every $15 \mathrm{~min}$, and physical and chemical processes are calculated at a $30 \mathrm{~min}$ time interval. For a more detailed description and an extended evaluation of the GCM we refer to Hourdin et al. (2006). The large-scale advection of tracers is calculated based on a monotonic finite-volume second-order scheme (Van Leer, 1977; Hourdin and Armengaud 1999). Deep convection is parameterized according to the scheme of Emanuel (1991). The turbulent mixing in the planetary boundary layer is based on a local second-order closure formalism. The transport and mixing of tracers in the LMDz GCM have been investigated and evaluated against observations for both inert and radioactive tracers (e.g., Hourdin and Issartel, 2000; Hauglustaine et al., 2004; Rivier et al., 2005) and in the framework of inverse modeling studies (e.g., Bousquet et al., 2005; Pison et al., 2009; Bousquet et al., 2010). These studies concluded that the model at this vertical resolution is well suited for the transport of tracers and chemical species. However, it was also pointed out that the simulated interhemispheric exchange time is 1.1 years for fossil $\mathrm{CO}_{2}$ (Hauglustaine et al., 2004), in the lowest part of the range (1.1-2.1 years) provided by the Atmospheric Tracer Transport Model Intercomparison Project (TransCom) intercomparison (Law et al., 1996). This means that LMDz has some of the fastest interhemispheric mixing among the models of TransCom and hence efficient vertical mixing and transport of pollutants. INCA includes a state-of-the-art $\mathrm{CH}_{4} / \mathrm{NO}_{\mathrm{x}} / \mathrm{CO} / \mathrm{NMHC} / \mathrm{O}_{3}$ tropospheric photochemistry (Hauglustaine et al., 2004; Folberth et al., 2006). The tropospheric photochemistry and aerosols scheme used in this model version is described through a total of 123 tracers, including 22 tracers to represent aerosols. The model includes 234 homogeneous chemical reactions, 43 photolytic reactions, and 30 heterogeneous reactions. Please refer to Hauglustaine et al. (2004) and Folberth et al. (2006) for the list of reactions included in the chemical scheme. The gas-phase version of the model has been extensively compared to observations in the lower troposphere (e.g., Hauglustaine et al., 2004; Folberth et al., 2006; Fiore et al., 2009; Reidmiller et al., 2009) and in the upper troposphere (e.g., Brunner et al., 2003; Dufour et al., 2007). For aerosols, the INCA model simulates the distribution of aerosols with anthropogenic sources such as sulfates, black carbon, and particulate organic matter, as well as natural aerosols such as sea salt and dust. The aerosol model keeps track of both the number and the mass of aerosols using a modal approach to treat the size distribution, which is described by a superposition of five log-normal modes (Schulz et al., 1998; Schulz, 2007), each with fixed spread. To treat the optically relevant aerosol size diversity, particle modes exist for three ranges: submicronic (diameter $<1 \mu \mathrm{m}$ ) corresponding to the accumulation mode, micronic (diameter between 1 and $10 \mu \mathrm{m}$ ) corresponding to coarse particles, and super-micronic or super coarse particles (diameter $>10 \mu \mathrm{m}$ ). This treatment in modes is computationally much more efficient compared to a bin scheme (Schulz et al., 1998). Furthermore, to account for the diversity in chemical composition, hygroscopicity, and mixing state, we distinguish between soluble and insoluble modes. In both sub-micron and micron size, soluble and insoluble aerosols are treated separately. Sea salt, $\mathrm{SO}_{4}$, and methane sulfonic acid (MSA) are treated as soluble components of the aerosol and dust is treated as insoluble, whereas black carbon (BC) and particulate organic matter (POM) appear both in the soluble and insoluble fractions. The ageing of primary insoluble carbonaceous particles transfers insoluble aerosol number and mass to soluble with a half-life of 1.1 days (Cooke and Wilson, 1996; Chung et al., 2002).

The uptake and loss of water from aerosol particles is generally fast and depends on the chemical composition, size, and surface properties of the aerosol particle. Aerosol water is responsible for about $50 \%$ of the global aerosol column load. This water uptake modifies the aerosol optical properties. We use a formulation of the optical depth, $\tau$, first implemented by Chin et al. (2002) to write $\tau$ as a function of the aerosol dry burden $M_{\mathrm{d}}\left(\mathrm{kg} \mathrm{m}^{-2}\right)$ :

$\tau=\beta M_{\mathrm{d}}$, 
where $\beta$, the specific extinction $\left(\mathrm{m}^{2} \mathrm{~kg}^{-1}\right)$, is computed as follows:

$\beta=3 Q M / 4 \rho r_{\mathrm{e}} M_{\mathrm{d}}$,

where $Q$ is the extinction coefficient (dimensionless) computed using Mie theory, $M$, is the aerosol burden per unit area $\left(\mathrm{kg} \mathrm{m}^{-2}\right), \rho$ is the particle density $\left(\mathrm{kg} \mathrm{m}^{-3}\right)$, and $r_{\mathrm{e}}$, the effective radius $(\mathrm{m})$. As relative humidity increases, this equation has to be modified to account for the presence of water. The density is then recomputed as the mass-weighted sum of the dry density of the aerosol and the density of water. The refractive index, hence the extinction, is also changed to account for water.

The optical properties and hygroscopic growth of sea salt were taken from Irshad et al. (2005). For sulfates, we followed the relationships published for ammonium sulfate by Martin et al. (2003). In the case of black carbon and organic carbon, we took the same dependence of hygroscopic growth on relative humidity as Chin et al. (2002). The aerosol scheme is thoroughly explained in Schulz (2007) and Balkanski (2011). Characteristic global aerosol properties of the INCA model have been described and compared in all AeroCom publications, as for instance recently in Myhre et al. (2013) and Koffi et al. (2012). We also refer to Szopa et al. (2012) for a simulation of the global aerosol components (excluding nitrates) and tropospheric ozone distributions and their associated radiative forcings between 1850 and 2100 following a recent historical emission data set (Lamarque et al., 2010) and under the representative concentration pathways (RCP) (Lamarque et al., 2011) for the future with the same version of this model.

\subsection{Ammonia and nitrate particles}

The LMDz-INCA chemical scheme has been extended in order to include the ammonia cycle and the nitrate particle formation. The various $\mathrm{NH}_{3}$ emissions have been introduced into the model as described in the next section. Ammonia undergoes several gas-phase reactions which have been introduced into the model chemical mechanism:

$$
\begin{aligned}
& \mathrm{NH}_{3}+\mathrm{OH} \rightarrow \mathrm{NH}_{2}+\mathrm{H}_{2}, \\
& \mathrm{NH}_{3}+\mathrm{O}^{1} \mathrm{D} \rightarrow \mathrm{NH}_{2}+\mathrm{OH}, \\
& \mathrm{NH}_{2}+\mathrm{NO}_{2} \rightarrow \mathrm{N}_{2} \mathrm{O}+\mathrm{H}_{2} \mathrm{O}, \\
& \mathrm{NH}_{2}+\mathrm{HO}_{2} \rightarrow \mathrm{NH}_{3}+\mathrm{O}_{2}, \\
& \mathrm{NH}_{2}+\mathrm{NO} \rightarrow \mathrm{N}_{2}+\mathrm{H}_{2} \mathrm{O}, \\
& \mathrm{NH}_{2}+\mathrm{O}_{3} \rightarrow \mathrm{NH}_{2} \mathrm{O}+\mathrm{O}_{2},
\end{aligned}
$$

$\mathrm{NH}_{2}+\mathrm{O}_{2} \rightarrow \mathrm{NO}+\mathrm{H}_{2} \mathrm{O}$

$\mathrm{NH}_{2} \mathrm{O}+\mathrm{O}_{3} \rightarrow \mathrm{NH}_{2}+2 \mathrm{O}_{2}$

$\mathrm{NH}_{2} \mathrm{O}+\mathrm{NO} \rightarrow \mathrm{NH}_{2}+\mathrm{NO}_{2}$

The rate constants for these reactions are taken from Sander et al. (2011).

The most abundant acids in the troposphere are sulfuric acid $\left(\mathrm{H}_{2} \mathrm{SO}_{4}\right)$ and nitric acid $\left(\mathrm{HNO}_{3}\right)$. Ammonia acts as the main neutralizing agent for these two species. Therefore, formulating the respective aerosol particle formation scheme as a purely sulfate-nitrate-ammonia system seems to be a reasonable assumption for a global chemistry-aerosol-climate model. However, we also remove nitric acid through reaction with sea salt and dust, as described below. As a first step, ammonium sulfate is formed instantaneously and irreversibly from $\mathrm{NH}_{3}$ and $\mathrm{H}_{2} \mathrm{SO}_{4}$, only limited by the availability of the less abundant of the two species. The concentration of $\mathrm{NH}_{3}$ and $\mathrm{SO}_{4}$ are depleted upon formation of ammonium sulfate which takes priority over ammonium nitrate formation due to the low vapor pressure of sulfuric acid:

$\mathrm{NH}_{3}+\mathrm{H}_{2} \mathrm{SO}_{4} \rightarrow\left(\mathrm{NH}_{4}\right) \mathrm{HSO}_{4}$,

$3 \mathrm{NH}_{3}+2 \mathrm{H}_{2} \mathrm{SO}_{4} \rightarrow\left(\mathrm{NH}_{4}\right)_{3} \mathrm{H}\left(\mathrm{SO}_{4}\right)_{2}$,

$2 \mathrm{NH}_{3}+\mathrm{H}_{2} \mathrm{SO}_{4} \rightarrow\left(\mathrm{NH}_{4}\right)_{2} \mathrm{SO}_{4}$

As in Metzger et al. (2002), three domains are considered to characterize the neutralization state of the ammonium sulfate ion formed, depending on the relative ammonia and sulfate concentrations. The total nitrate $\left(T_{\mathrm{N}}\right)$, total ammonia $\left(T_{\mathrm{A}}\right)$, and total sulfate $\left(T_{\mathrm{S}}\right)$ concentrations are defined as

$T_{\mathrm{N}}=\left[\mathrm{HNO}_{3}\right]+\left[\mathrm{NO}_{3}^{-}\right]$,

$T_{\mathrm{A}}=\left[\mathrm{NH}_{3}\right]+\left[\mathrm{NH}_{4}^{+}\right]$,

$T_{\mathrm{S}}=\left[\mathrm{SO}_{4}^{\overline{=}}\right]$.

If $T_{\mathrm{A}}>2 T_{\mathrm{S}}$, ammonia rich condition (sulfate state $\Gamma=$ 2.0 ), the reaction pathway is provided by the chemical Reaction (R10c); if $\mathrm{T}_{\mathrm{A}}<2 \mathrm{~T}_{\mathrm{S}}$, sulfate rich condition (sulfate state $\Gamma=1.5$ ), Reaction (R10b) is considered; and if $T_{\mathrm{A}}<T_{\mathrm{S}}$, sulfate very rich condition (sulfate state $\Gamma=1.0$ ), the reaction occurs through Reaction (R10a).

In a second step, if all free ammonia is consumed by the sulfate forming reaction, no ammonium nitrate is formed. If free ammonia persists, it is used for the neutralization of nitric acid to ammonium nitrate aerosol following the equilibrium reaction:

$\mathrm{HNO}_{3}+\mathrm{NH}_{3} \leftrightarrow \mathrm{NH}_{4} \mathrm{NO}_{3}$.

The equilibrium constant $\left(K_{\mathrm{p}}\right)$ of Reaction (R11) strongly depends on relative humidity and temperature. The parameterization used for this dependence is based on 
Mozurkewich (1993), and the deliquescence relative humidity is calculated based on Seinfeld and Pandis (1998) (see Supplement for more details).

The equilibrium concentration of ammonium nitrate is then calculated based on Seinfeld and Pandis (1998). The free ammonia in the system is defined as the total ammonia minus the ammonia required to neutralize the available sulfate:

$T_{\mathrm{A}}^{*}=T_{\mathrm{A}}-\Gamma T_{\mathrm{S}}$.

If $T_{\mathrm{N}} T_{\mathrm{A}}^{*}>K_{\mathrm{p}}$, the ammonium nitrate concentration is calculated according to

$$
\left[\mathrm{NH}_{4} \mathrm{NO}_{3}\right]=\frac{1}{2}\left[T_{\mathrm{A}}^{*}+T_{\mathrm{N}}-\sqrt{\left(T_{\mathrm{A}}^{*}+T_{\mathrm{N}}\right)^{2}-4\left(T_{\mathrm{N}} \mathrm{T}_{\mathrm{A}}^{*}-K_{\mathrm{p}}\right)}\right] .
$$

Elsewhere, ammonium nitrate dissociates and $\left[\mathrm{NH}_{4} \mathrm{NO}_{3}\right]=0$. The concentration of $\mathrm{NH}_{3}$ and $\mathrm{HNO}_{3}$ are depleted or replenished to account for ammonium nitrate formation or dissociation, respectively. The chemical formation of ammonium sulfate particles according to Reaction (R10) and of ammonium nitrate particles according to Reaction (R11) goes into the accumulation mode. The formation of nitrates through Reaction (R11) is also associated with a corresponding increase in the number of particles in the accumulation mode, reflecting the formation of new ammonium nitrate particles. This thermodynamic model has been run as a box model and the results carefully evaluated against the reference model ISORROPIA version 2.1 (Nenes et al., 1998). For this evaluation, the main parameters controlling the nitrate and ammonium aerosol concentrations have been varied over specified intervals and the calculated concentrations compared to ISORROPIA results. An excellent agreement between both model results has been achieved over the range of key parameters currently encountered in the global model version, with some larger variations (> 20\%) at temperatures higher than 295K (see Supplement for more details).

Gaseous $\mathrm{HNO}_{3}$ can condense on both accumulation mode and coarse particles. As in Myhre et al. (2006), numerically, photochemistry and formation of accumulation mode aerosols are first solved because the smaller particles reach equilibrium faster than the larger ones. After the small particles are in equilibrium, the concentration of gaseous $\mathrm{HNO}_{3}$ is updated for the condensation on coarse particles. We account for the heterogeneous reaction of $\mathrm{HNO}_{3}$ with dust and sea-salt particles:

$\mathrm{HNO}_{3}+\mathrm{NaCl} \rightarrow \mathrm{NaNO}_{3}+\mathrm{HCl}$,

$2 \mathrm{HNO}_{3}+\mathrm{CaCO}_{3} \rightarrow \mathrm{Ca}\left(\mathrm{NO}_{3}\right)_{2}+\mathrm{H}_{2} \mathrm{CO}_{3}$.

We use a standard first-order reactive uptake parameterization to represent the uptake of $\mathrm{HNO}_{3}$ on pre-existing dust and sea-salt particles in the model and formation of coarse nitrate particles (Dentener and Crutzen, 1993; Bauer et al., 2004; Fairlie et al., 2010). The rate constants $k_{12}$ and $k_{13}$ of Reactions (R12) and (R13), which describe the loss of $\mathrm{HNO}_{3}$ from the gas phase, are calculated from (Schwartz, 1986)

$k_{12,13}=\int_{r_{\mathrm{i}}}^{r_{\mathrm{f}}} 4 \pi r^{2} N(r)\left(\frac{r}{D_{\mathrm{g}}}+\frac{4}{v \gamma}\right)^{-1} \mathrm{~d} r$,

where $N$ is the number density of dust or sea-salt particles of radius $[r, r+\mathrm{d} r], D_{\mathrm{g}}$ is the calculated, pressureand temperature-dependent, molecular diffusion coefficient $\left(\mathrm{cm}^{2} \mathrm{~s}^{-1}\right), v$ the calculated, temperature-dependent, mean molecular speed $\left(\mathrm{cm} \mathrm{s}^{-1}\right)$, and $\gamma$ the reactive uptake coefficient. Equation (8) is integrated from $r_{\mathrm{i}}=0.01$ to $r_{\mathrm{f}}=30 \mu \mathrm{m}$. As mentioned by Feng et al. (2007), a major limitation of this first-order formulation is the lack of relative humidity dependence for the uptake. To partly overcome this limitation, for the reaction on dust particles, we use the RH-dependent uptake coefficient proposed by Fairlie et al. (2010). Based on this RH dependence, $\gamma$ increases from $1 \times 10^{-5}$ for RH lower than $10 \%$ up to $1.05 \times 10^{-3}$ for RH larger than $80 \%$. Another limitation mentioned by Feng et al. (2007) is the lack of dependence of the uptake coefficient on the aerosol chemical composition. As in Fairlie et al. (2010), we introduce a $\mathrm{Ca}^{2+}$ limitation for the uptake of $\mathrm{HNO}_{3}$ on dust through Reaction (R13). Based on dust source maps (Claquin et al., 1999), it is assumed than $\mathrm{Ca}^{2+}$ constitutes $5 \%$ of the dust mass. Dust alkalinity is then consumed by the uptake of $\mathrm{HNO}_{3}$. Once the alkalinity is titrated by the formation of nitrates, the uptake of $\mathrm{HNO}_{3}$ through (R13) ceases. For seasalt particles, the same dependence is used for the $\gamma$ increase with RH. The values are scaled to the accommodation coefficients compiled by Sander et al. (2011) and $\gamma$ increases from $1 \times 10^{-3}$ for RH lower than $10 \%$ up to $1 \times 10^{-1}$ for RH larger than $80 \%$. No alkalinity limitation is considered for sea-salt particles.

These new gaseous species and particles introduced into the model to represent the ammonia cycle, the formation of ammonium sulfate, ammonium nitrate, and coarse nitrates on dust and sea salt are subject to the same transport and mixing processes as the other tracers in the model. The dry and wet deposition of $\mathrm{NH}_{3}$ is introduced as described by Hauglustaine et al. (2004), with a Henry's law coefficient taken from Sander et al. (2011). Ammonium nitrate and ammonium sulfate are subject to the same dry and wet deposition processes as sulfate particles already in the model, and coarse nitrates on dust and sea salt are deposited as the corresponding dust and sea-salt components, respectively.

The hygroscopic growth of ammonium nitrate has been characterized in the laboratory by measuring droplet growth for different conditions of relative humidity by Tang (1996). The optical properties of nitrate particles in the accumulation and coarse modes were obtained through Mie calculation using the refractive indices for two overlapping spectral 
intervals. Gosse et al. (1997) measured the refractive index of ammonium nitrate from 0.7 to $2.6 \mu \mathrm{m}$, whereas Jarzembski et al. (2003) covered the far visible to the infrared wavelengths from 2.0 to $20 \mu \mathrm{m}$. Values of specific extinction, asymmetry parameter and single scattering albedo were tabulated for eleven values of relative humidities: from 0 to $90 \%$ in $10 \%$ increments and finally for the $95 \%$ value. For a given relative humidity, we interpolate between the two closest values; if relative humidity exceeds $95 \%$, then we take for optical parameters the values deduced from the Mie theory at $95 \%$ relative humidity.

\subsection{Model setup}

For the simulation of "present" (2000) and "pre-industrial" (1850) conditions, the anthropogenic emissions compiled by Lamarque et al. (2010) are added to the natural fluxes used in the INCA model. All natural emissions are kept at their present-day levels. For organic aerosols, the secondary organic matter formed from biogenic emissions is equal to that provided by the AeroCom emission data set (Dentener et al., 2006a). The ORCHIDEE vegetation model has been used to calculate offline the biogenic surface fluxes of isoprene, terpenes, acetone, and methanol, as well as NO soil emissions as described by Lathière et al. (2006). $\mathrm{NH}_{3}$ emissions from natural soils and ocean are taken from Bouwman et al. (1997). Natural emissions of dust and sea salt are computed using the $10 \mathrm{~m}$ wind components from the European Centre for Medium-Range Weather Forecasts (ECMWF) reanalysis for 2006 and, consequently, have seasonal cycles but no interannual variability. For the future simulations (2030, 2050, 2100), the four representative concentration pathways (RCP) anthropogenic and biomass burning emissions provided by Lamarque et al. (2011) are used. Methodological elements used to build these projections can be found in Lamarque et al. (2011). Natural emissions for both gaseous species and particles are kept to their present-day level as described above. Table 1 gives the list of simulations performed and the corresponding total and global emissions of key species discussed in this paper. In all RCP scenarios, fossil fuel-driven emissions, $\mathrm{NO}_{\mathrm{x}}, \mathrm{SO}_{2}, \mathrm{BC}$, and organic carbon (OC), decrease in 2100 compared to 2000 emissions. It is, however, interesting to note that $\mathrm{NH}_{3}$ emissions, driven by agriculture, increase in all scenarios from $50 \mathrm{Tg} \mathrm{N}$ in 2000 to 54-79 $\mathrm{Tg} \mathrm{N}$ in 2100 depending on the considered scenario. As will be discussed in the next sections, this feature will have major implications in terms of the nitrate future radiative forcing of climate.

In this study, meteorological data from the ECMWF reanalysis have been used. The relaxation of the GCM winds towards ECMWF meteorology is performed by applying at each time step a correction term to the GCM $\boldsymbol{u}$ and $\boldsymbol{v}$ wind components with a relaxation time of $2.5 \mathrm{~h}$ (Hourdin and Issartel, 2000; Hauglustaine et al., 2004). The ECMWF fields are provided every $6 \mathrm{~h}$ and interpolated onto the LMDz grid.
Table 1. Total (anthropogenic plus natural) and global emissions of $\mathrm{NO}_{\mathrm{x}}$ and $\mathrm{NH}_{3}\left(\mathrm{Tg} \mathrm{Nyr}^{-1}\right), \mathrm{SO}_{2}\left(\mathrm{Tg} \mathrm{S} \mathrm{yr}^{-1}\right)$, black carbon (BC) and organic carbon (OC) $\left(\mathrm{Tg} \mathrm{yr}^{-1}\right)$ for the various simulations performed in this study.

\begin{tabular}{|c|c|c|c|c|c|}
\hline Scenario & $\mathrm{NO}_{\mathrm{x}}$ & $\mathrm{NH}_{3}$ & $\mathrm{SO}_{2}$ & $\mathrm{BC}$ & $\mathrm{OC}$ \\
\hline 1850 & 10 & 21 & 10 & 3 & 22 \\
\hline 2000 & 46 & 50 & 59 & 8 & 36 \\
\hline 2030 RCP2.6 & 39 & 62 & 35 & 7 & 36 \\
\hline 2050 RCP2.6 & 36 & 67 & 22 & 5 & 30 \\
\hline $2100 \mathrm{RCP} 2.6$ & 24 & 79 & 14 & 3 & 25 \\
\hline $2030 \mathrm{RCP} 4.5$ & 42 & 56 & 49 & 7 & 29 \\
\hline $2050 \mathrm{RCP} 4.5$ & 36 & 57 & 32 & 6 & 27 \\
\hline $2100 \mathrm{RCP} 4.5$ & 24 & 54 & 18 & 4 & 19 \\
\hline 2030 RCP6.0 & 40 & 57 & 45 & 7 & 36 \\
\hline 2050 RCP6.0 & 37 & 64 & 43 & 7 & 36 \\
\hline 2100 RCP6.0 & 23 & 72 & 17 & 4 & 32 \\
\hline 2030 RCP8.5 & 48 & 63 & 48 & 7 & 33 \\
\hline $2050 \mathrm{RCP} 8.5$ & 40 & 69 & 32 & 6 & 30 \\
\hline 2100 RCP8.5 & 31 & 78 & 20 & 4 & 24 \\
\hline \multicolumn{6}{|c|}{ Sensitivity simulations } \\
\hline $2100 \mathrm{RCP} 4.5-\mathrm{NO}_{\mathrm{x}}$ & 31 & 54 & 18 & 4 & 19 \\
\hline $2100 \mathrm{RCP} 4.5-\mathrm{NH}_{3}$ & 24 & 78 & 18 & 4 & 19 \\
\hline $2100 \mathrm{RCP} 4.5-\mathrm{SO}_{2}$ & 24 & 54 & 59 & 4 & 19 \\
\hline
\end{tabular}

We focus this work on the distribution of nitrate particles, its evolution under future anthropogenic emissions, and its direct radiative forcing of climate. In order to isolate the impact of anthropogenic emission scenarios, all snapshot simulations are performed under present-day climate conditions and run for a period of 2 years. Therefore, ECMWF meteorological data for 2005-2006 are used. The results for the year 2005 are used as a spin-up. Results for 2006 conditions are presented in the next sections. The impact of climate change on particles and chemistry is therefore not included in the results. The role played by climate change and the impact of nitrate on the indirect aerosol radiative forcing of climate will be investigated in a forthcoming study.

\section{Present-day distributions}

\subsection{Simulated aerosol distributions}

In this section we present the distributions of gaseous species and aerosols involved in the formation of nitrate particles. Figure 1 shows the present-day annual mean surface concentration of sulfates $\left(\mathrm{SO}_{4}^{=}\right)$, ammonium $\left(\mathrm{NH}_{4}^{+}\right)$, and total (fine plus coarse) nitrates $\left(\mathrm{NO}_{3}^{-}\right)$aerosols. Please note that all concentrations and burdens are expressed in the following sections in mass of the species (e.g., $\mu \mathrm{g} \mathrm{m}^{-3}$ for $\mu \mathrm{g} \mathrm{NO}_{3} \mathrm{~m}^{-3}$ ) unless otherwise stated (e.g., $\mu \mathrm{g} \mathrm{N} \mathrm{m}^{-3}$ or 

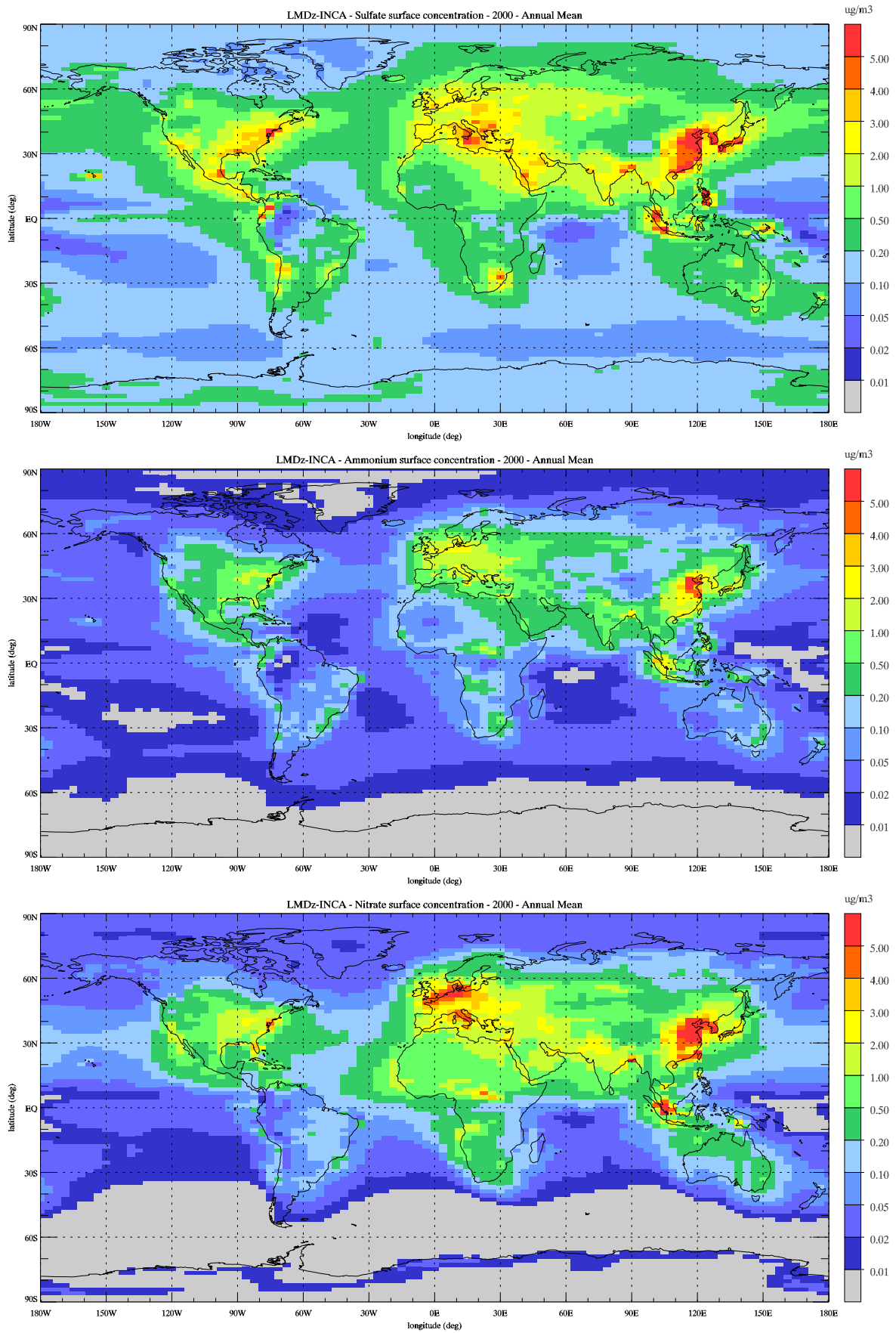

Figure 1. Annual mean surface concentration of (top) sulfate aerosols, (middle) ammonium aerosols, and (bottom) total nitrate aerosols simulated for present-day conditions $\left(\mu \mathrm{g} \mathrm{m}^{-3}\right)$.

$\mu \mathrm{g} \mathrm{S} \mathrm{m}{ }^{-3}$ ). Maximum sulfate concentrations are calculated over regions of high $\mathrm{SO}_{2}$ emissions with marked maxima reaching 4-5 $\mu \mathrm{g} \mathrm{m}^{-3}$ over the eastern United States, southern and eastern Europe, and China. The concentration of ammonium (associated both with ammonium sulfate and ammonium nitrate) is localized over continental regions and reaches maxima of $1-2 \mu \mathrm{g} \mathrm{m}^{-3}$ over the central and east- ern United States, $2-3 \mu \mathrm{g} \mathrm{m}^{-3}$ in northern Europe, and 4$5 \mu \mathrm{g} \mathrm{m}^{-3}$ in northern China. These regions combine both high concentrations of sulfates and nitric acid but also high agricultural emissions of $\mathrm{NH}_{3}$. The distribution of surface nitrates (fine mode plus coarse mode) shows very strong concentrations in regions of high ammonia and nitric acid concentrations (see below). This is particularly the case over 
northern Europe and China, with concentrations reaching 4$5 \mu \mathrm{g} \mathrm{m}^{-3}$. The patterns of these surface distributions for the three aerosol components are in general agreement with the recent global model results presented by Pringle et al. (2010) and Xu and Penner (2012) and with the nitrate distributions calculated by Myhre et al. (2006) and Bauer et al. (2007).

Figure 2 decomposes the total surface nitrate concentration shown in Fig. 1 into its three components: accumulation mode, coarse mode on dust particles and coarse mode on seasalt particles. The conditions for fine-mode nitrate particle formation (expressed by Eq. 7) are met over the continents and maximum concentrations are calculated, as already seen in Fig. 1, over regions of high agricultural emissions of $\mathrm{NH}_{3}$ or high $\mathrm{HNO}_{3}$ concentrations. Coarse nitrate on dust follow the distribution of dust particles in the model (Bauer et al., 2004). High concentrations reaching more than $0.5 \mu \mathrm{g} \mathrm{m}^{-3}$, and locally up to $1-3 \mu \mathrm{g} \mathrm{m}^{-3}$, are calculated over the Sahara and the Arabian Peninsula and extend to the Mediterranean Sea and southern Europe; over the western United States and over China. In contrast, coarse nitrate on sea-salt reaches concentrations of $0.5-1 \mu \mathrm{g} \mathrm{m}^{-3}$ in coastal areas where high concentrations of sea salt and nitric acid are met. These two coarse nitrate components add up to a total of about 0.1$0.2 \mu \mathrm{g} \mathrm{m}^{-3}$ over the ocean. Over the continents, fine-mode nitrates significantly dominate over source regions. However, in coastal regions or in southern Europe all components mix, and coarse nitrates can contribute to $30-40 \%$ to the total concentration in these specific areas. The pattern of the calculated distribution of coarse nitrates on dust and sea salt is in fairly good agreement with the results presented by Myhre et al. (2006), Bauer et al. (2007), and Xu and Penner (2012).

In order to evaluate the model results, we have compared the simulated and measured surface concentrations of $\mathrm{SO}_{4}^{=}$, $\mathrm{NH}_{4}^{+}$, and $\mathrm{NO}_{3}^{-}$from the EBAS database at the Norwegian Institute for Air Research (NILU). EBAS holds data from the European Monitoring and Evaluation Programme (EMEP) (emep.int), from the US National Atmospheric Deposition Program/National Trend Network (NADP/NTN; http: //nadp.sws.uiuc.edu/NTN), from the US Interagency Monitoring of Protected Visual Environments (IMPROVE; http:// vista.cira.colostate.edu/IMPROVE), from the Clean Air Status and Trends Network (CASTNET; http://java.epa.gov/ castnet), and the EANET, Data on the Acid Deposition in the East Asian Region (http://www.eanet.cc/). These comparisons have been prepared using the AeroCom evaluation tools (Schulz et al., 2006). The aerosols measurements are mostly from the CASTNET/IMPROVE network over North America and from the EMEP network in Europe. This evaluation is performed for the year 2006 based on matching daily mean data, averaged to monthly means. Table 2 summarizes the comparison with the measurements (see Supplement for individual plots per region and per species). $\mathrm{For}_{\mathrm{SO}}^{=}$, the normalized mean bias (difference between the arithmetic mean of the model minus the arithmetic mean of the mea- surements relative to the mean measurements) is $+20 \%$ for Europe and $+21 \%$ for North America. Worldwide, the normalized mean bias (NMB) is $+20 \%$. For ammonium concentrations, the evaluation shows that $\mathrm{NH}_{4}^{+}$is overestimated worldwide with a NMB of $+50 \%$. Over Europe, the NMB is $+62 \%$ and, in contrast, $\mathrm{NH}_{4}^{+}$is slightly underestimated over North America with a NMB of $-16 \%$. For nitrate concentrations, a worldwide overestimate is obtained with a NMB of $+68 \%$. The comparison with the measurements are more contrasted over the two regions, with a smaller bias but smaller correlation over Europe $(\mathrm{NMB}=+64 \%, R=0.43$ ) than over North America (NMB $=+115 \%, R=0.54)$. For $\mathrm{NO}_{3}^{-}$, the bias is mainly driven by an overestimate of observed concentrations in summer $(\mathrm{NMB}=+143 \%$, worldwide) compared to winter ( $\mathrm{NMB}=+22 \%$ ). These comparisons are fairly good considering the difficulty of representing station measurements with a large-scale atmospheric model. The comparison made for a specific year (2006) using an emission inventory representative of the year 2000 is also a source of bias, which we estimate to be on the order of $10-30 \%$ for European and American sites (Schulz et al., 2013). These results are generally in line with the comparisons obtained with more detailed aerosol models (Adams et al., 1999; Park et al., 2004; Pringle et al., 2010; Xu et al., 2012; Zhang et al., 2012; Heald et al., 2012) or with a model of the same complexity (Bellouin et al., 2011). In particular, these studies showed the difficulty of representing nitrates particles, which are currently overestimated by a factor of two at the surface, by the global models due to the coarse model resolution, the simplified aerosol chemistry, and the limitations associated with the representation of physics and transport in those models. In addition, it should be noted that a positive bias in simulated nitrate aerosol is suspected to be partly linked to negative sampling artifacts in measurements because evaporation of ammonium nitrate has been frequently reported to create occasional losses of up to $50 \%$, particularly in warm weather (see Supplement for more details). Further work is needed to better characterize the individual nitrate measurement error to see where modeled nitrate is consistent with measurements.

It should also be noted that we focus this paper on monthly mean and annual mean distributions of nitrate particles and their long-term evolution during the 21 st century. However, nitrate aerosols have the ability to evaporate back into the gas phase. As a consequence, and as illustrated for instance by ten Brink et al. (2007), Dall'Osto et al. (2009), Schaap et al. (2011), and Mensah et al. (2012), this means that nitrates have a pronounced diurnal cycle and spend most of the daytime in the gas phase. This implies that the radiative forcing also has a pronounced diurnal cycle. The detailed evaluation of the diurnal cycle is out of the scope of global model use and of this paper. However, with a timestep of $30 \mathrm{~min}$ for chemistry, a full diurnal cycle is simulated by LMDz-INCA. We found a pronounced diurnal cycle in the model results associated with diurnal boundary layer development and higher 

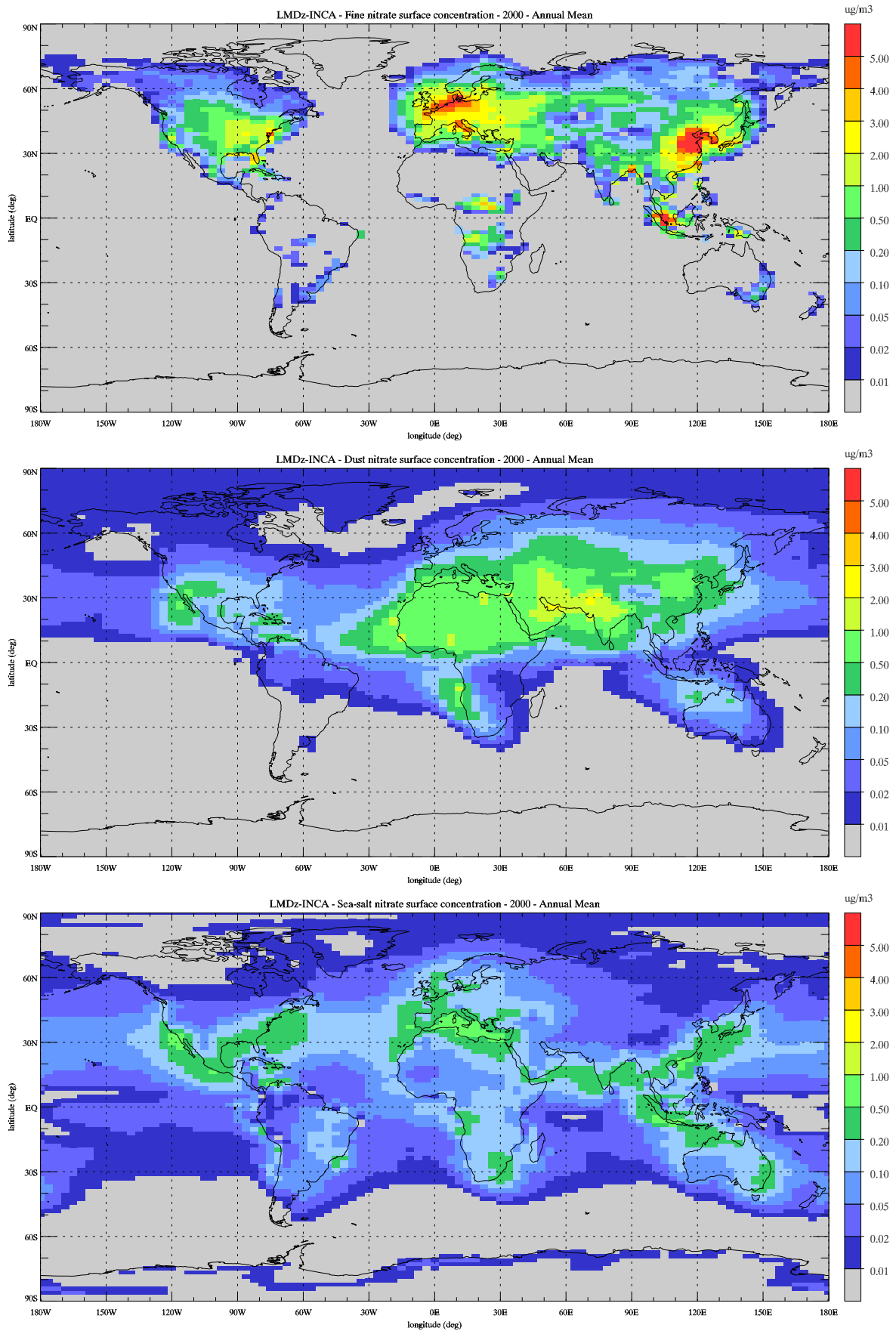

Figure 2. Annual mean surface concentration of (top) fine-mode nitrate aerosols, (middle) coarse-mode nitrates on dust, and (bottom) coarsemode nitrates on sea-salt simulated for present-day conditions $\left(\mu \mathrm{g} \mathrm{m}^{-3}\right)$.

nitrate instability at higher temperatures superimposed on a variability associated with meteorological conditions and to transport of pollution episodes. The simulated concentrations of nitrates, their diurnal cycle, and day-to-day variability are generally in line with diurnally resolved monitoring data (see Supplement).
Figure 3 shows the column burden of $\mathrm{SO}_{4}^{=}, \mathrm{NH}_{4}^{+}$, and total $\mathrm{NO}_{3}^{-}$. The sulfates column reaches more than $3 \mathrm{mg} \mathrm{m}^{-2}$ over the continents in the Northern Hemisphere. In the eastern US and northern and central Europe, the column reaches more than $5 \mathrm{mg} \mathrm{m}^{-2}$. The maximum column of more than $10 \mathrm{mg} \mathrm{m}^{-2}$ is reached over China. These values are slightly higher than the column of $1-2 \mathrm{mg} \mathrm{m}^{-2}$ calculated over the 
Table 2. Normalized mean bias (NMB, \%) and correlation coefficient $(R)$ of model results versus EBAS measurements for the year 2006 and for various regions and worldwide for surface concentrations of $\mathrm{SO}_{4}, \mathrm{NH}_{4}$, and $\mathrm{NO}_{3}$, wet deposition of $\mathrm{SO}_{\mathrm{x}}, \mathrm{NH}_{\mathrm{x}}$, and $\mathrm{NO}_{\mathrm{y}}$, and simulated total aerosol optical depth at $550 \mathrm{~nm}$ compared to AERONET data.

\begin{tabular}{|c|c|c|c|c|c|c|}
\hline & & Europe & $\begin{array}{l}\text { North } \\
\text { America }\end{array}$ & $\begin{array}{l}\text { Eastern } \\
\text { Asia }\end{array}$ & $\begin{array}{l}\text { Northern } \\
\text { Africa }\end{array}$ & Worldwide \\
\hline & \multicolumn{6}{|c|}{ Concentrations $\left(\mu \mathrm{g} \mathrm{S}-\mathrm{N} \mathrm{m}^{-3}\right)$} \\
\hline \multirow{2}{*}{$\mathrm{SO}_{4}$} & NMB & $20 \%$ & $21 \%$ & \multirow{2}{*}{ N.A. } & \multirow{2}{*}{ N.A. } & $20 \%$ \\
\hline & & 0.58 & 0.68 & & & 0.66 \\
\hline \multirow{2}{*}{$\mathrm{NH}_{4}$} & NMB & $62 \%$ & $-16 \%$ & \multirow{2}{*}{ N.A. } & \multirow{2}{*}{ N.A. } & $50 \%$ \\
\hline & & $R 0.43$ & 0.77 & & & 0.51 \\
\hline \multirow{3}{*}{$\mathrm{NO}_{3}$} & NMB & $64 \%$ & $115 \%$ & \multirow{2}{*}{ N.A. } & \multirow{2}{*}{ N.A. } & $68 \%$ \\
\hline & $R$ & 0.43 & 0.54 & & & 0.59 \\
\hline & \multicolumn{6}{|c|}{ Wet deposition $\left(\mu \mathrm{g} \mathrm{S}-\mathrm{N} \mathrm{m}^{-2} \mathrm{yr}^{-1}\right)$} \\
\hline \multirow{2}{*}{$\mathrm{SO}_{4}$} & NMB & $-27 \%$ & $-20 \%$ & $-80 \%$ & \multirow{2}{*}{ N.A. } & $-59 \%$ \\
\hline & $R$ & 0.47 & 0.70 & 0.60 & & 0.31 \\
\hline \multirow{2}{*}{$\mathrm{NH}_{\mathrm{x}}$} & NMB & $-4.5 \%$ & $-32 \%$ & $-60 \%$ & \multirow{2}{*}{ N.A. } & $-34 \%$ \\
\hline & $R$ & 0.33 & 0.46 & 0.42 & & 0.24 \\
\hline \multirow{3}{*}{$\mathrm{NO}_{\mathrm{y}}$} & NMB & $-28 \%$ & $13 \%$ & $-54 \%$ & \multirow{2}{*}{ N.A. } & $-40 \%$ \\
\hline & $R$ & 0.49 & 0.73 & 0.24 & & 0.19 \\
\hline & Total a & rosol opti & al depth & & & \\
\hline \multirow{2}{*}{ AOD } & NMB & $6 \%$ & $-4.5 \%$ & $-10 \%$ & $-39 \%$ & $-11 \%$ \\
\hline & $R$ & 0.58 & 0.77 & 0.66 & 0.64 & 0.57 \\
\hline
\end{tabular}

continents by Pringle et al. (2010) with a more complex aerosol microphysics and partitioning model. The global mean column burden for $\mathrm{SO}_{4}^{=}$is $2.5 \mathrm{mg} \mathrm{m}^{-2}$, in the upper range of the recent model intercomparison by Myhre et al. (2013), who reported a mean burden of $1.9 \pm 0.5 \mathrm{mg} \mathrm{m}^{-2}$. The evaluation of the aerosol optical depth will be important for evaluating those results (see below). The column burden of $\mathrm{NH}_{4}^{+}$reaches $1-3 \mathrm{mg} \mathrm{m}^{-2}$ over source regions in the Northern Hemisphere. Maximum values reaching 5$10 \mathrm{mg} \mathrm{m}^{-2}$ are calculated over northern China. This distribution is very close to the burden calculated by Pringle et al. (2010) but exhibits somewhat lower maximum values. The global mean burden for $\mathrm{NH}_{4}^{+}$is $0.54 \mathrm{mg} \mathrm{m}^{-2}$. The total (coarse plus fine) nitrate aerosol column shows a strong maximum of $5-10 \mathrm{mg} \mathrm{m}^{2}$ over northern and southern Europe, India, China, and Africa. A secondary maximum of $3-4 \mathrm{mg} \mathrm{m}^{-2}$ is also calculated over the central US. This distribution is in agreement with the burden illustrated by Myhre et al. (2006) and Pringle et al. (2010). The global mean total nitrate burden is $1.56 \mathrm{mg} \mathrm{m}^{-2}$. Fine nitrate particles associated with anthropogenic emissions contribute, to a large extent, to the maximum calculated in the central US, northern Europe and over the Po Valley, in northern India and in China. Over Africa, Saudi Arabia, central Europe, and in northern China, nitrates on dust contribute more than $4-10 \mathrm{mg} \mathrm{m}^{-2}$ to the nitrate column (see Supplement). Over the Mediterranean and in southern Europe, the contribution of coarse nitrates on dust represents about $50 \%$ of the calculated total nitrate column, a proportion in agreement with the measurements by Putaud et al. (2004b). These results are in line with the fine and coarse particles plumes calculated by Fairlie et al. (2010) off the coast of China. The contribution of nitrates on sea salt is lower and generally close to $0.5 \mathrm{mg} \mathrm{m}^{-2}$ over the continents. It only reaches $1 \mathrm{mg} \mathrm{m}^{2}$ in localized areas, in particular off the coast of the eastern US or over the Mediterranean where both pollution and sea-salt particles are present. This is somewhat in contrast with Myhre et al. (2006), who calculated a larger and more localized contribution of sea salt to the total nitrate column over northern Europe reaching more than 1$1.5 \mathrm{mg} \mathrm{m}^{-2}$. The global mean burden of fine-mode nitrate is $0.44 \mathrm{mg} \mathrm{m}^{-2}$. Nitrates on dust and on sea salt contribute, respectively, $0.65 \mathrm{mg} \mathrm{m}^{-2}$ and $0.48 \mathrm{mg} \mathrm{m}^{-2}$ to the coarse nitrate global burden. This corresponds to a relative contribution of fine-mode nitrates of $28 \%$ of the total nitrate burden in this model, to be compared to the $21 \%$ calculated by Bauer et al. (2007) and to the $23 \%$ calculated by Xu and Penner (2012).

As discussed in Sect. 2, the formation of fine nitrate particles depends on both the ammonia and nitric acid concentrations. Figure 4 shows the annual mean surface concentration of $\mathrm{NH}_{3}$ and $\mathrm{HNO}_{3}$. The concentration of ammonia reaches more than $1-2 \mu \mathrm{g} \mathrm{m}^{-3}$ where agricultural emissions are high, in particular over northern Europe, in the central United States, the Ganges valley, and northern China. In northern Europe, India, and China, the concentration reaches more 

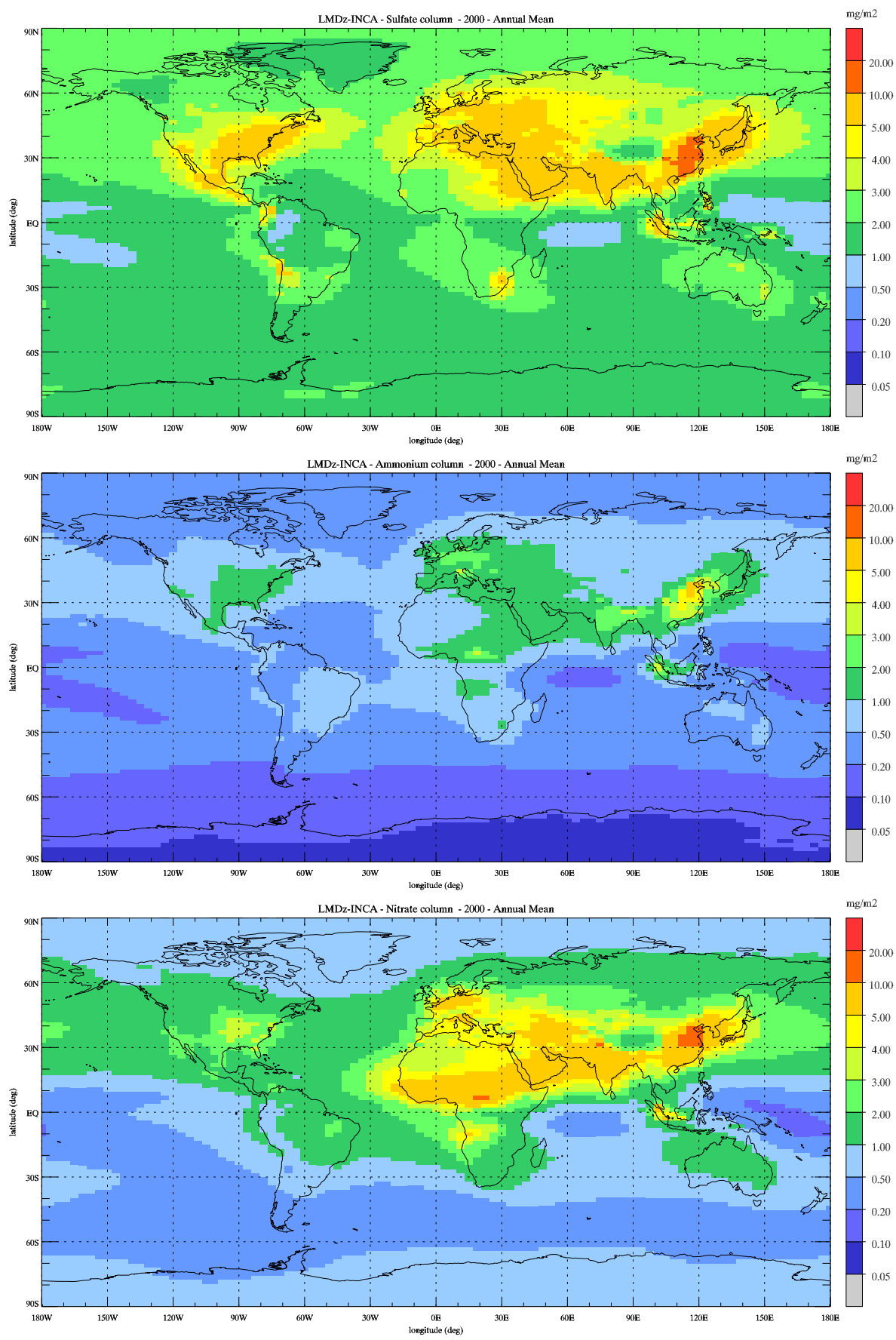

Figure 3. Annual mean tropospheric column of (top) sulfate aerosols, (middle) ammonium aerosols, and (bottom) total nitrate aerosols simulated for present-day conditions $\left(\mathrm{mg} \mathrm{m}^{-2}\right)$.

than $5 \mu \mathrm{g} \mathrm{m}^{-3}$. Biomass burning also contributes to higher concentrations in Indonesia, Africa, and South America. This distribution is very much in line with the column density measured by the infrared atmospheric sounding interferometer (IASI) instrument (Clarisse et al., 2009) and a more detailed and quantitative evaluation of the $\mathrm{NH}_{3}$ results with the remote sensing data will be presented in forthcoming stud- ies. Nitric acid shows high concentrations of $3-5 \mu \mathrm{g} \mathrm{m} \mathrm{m}^{-3}$ in regions of high anthropogenic $\mathrm{NO}_{\mathrm{x}}$ emissions. This is particularly the case over the eastern United States and to a lesser extent in California. In Europe, the concentration reaches 1$2 \mu \mathrm{g} \mathrm{m}^{-3}$ with a marked maximum over the Mediterranean Sea where pollution accumulates. A more detailed evaluation of nitric acid has been provided elsewhere (Hauglustaine et 

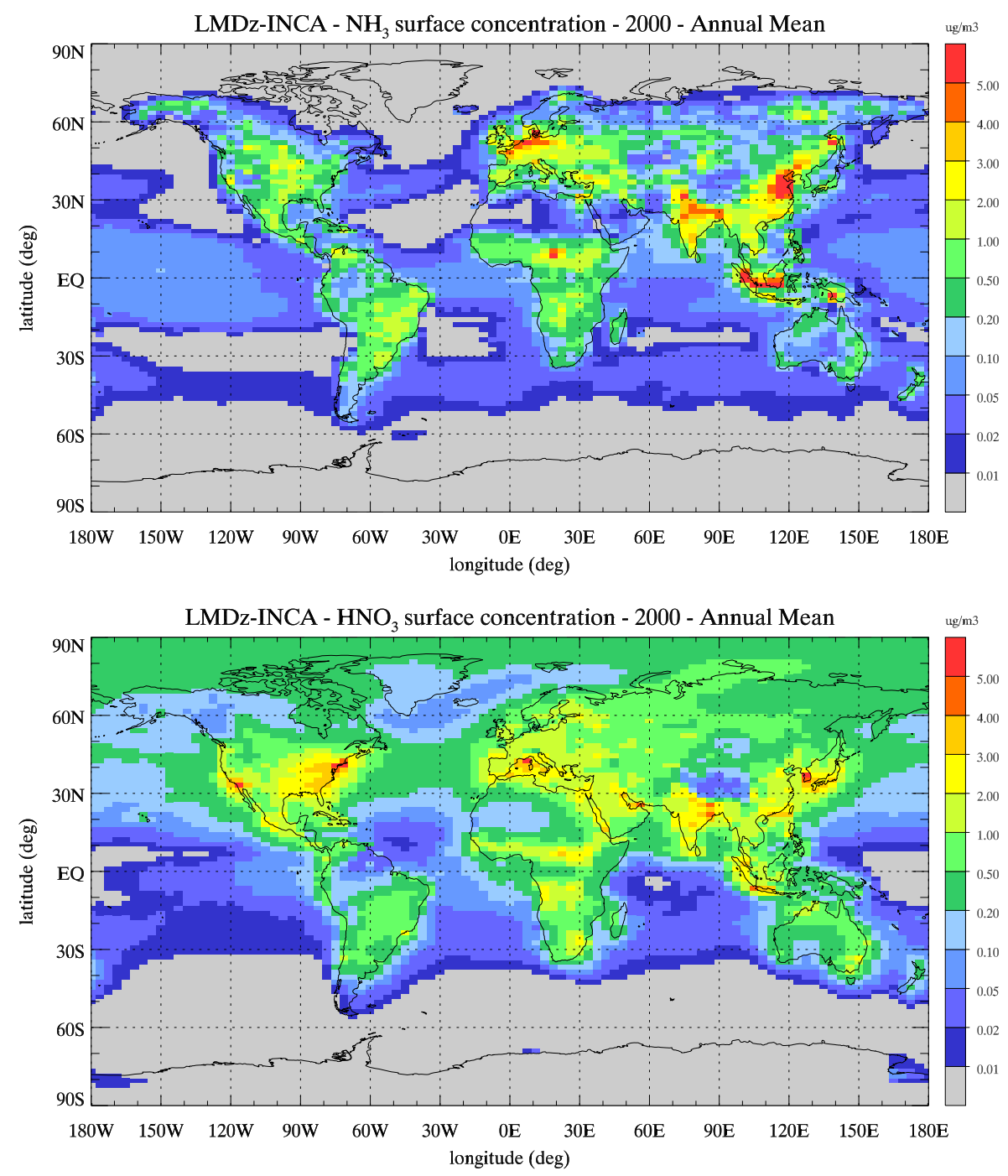

Figure 4. Annual mean surface concentration of (top) ammonia and (bottom) nitric acid simulated for present-day conditions $\left(\mu \mathrm{g} \mathrm{m}^{-3}\right.$ ).

al., 2004; Folberth et al., 2006), although in a model version without a particle formation loss term, which we estimate in budget calculations to be approximately one-third, see below. These distributions are in very good agreement with the results shown for instance by Xu and Penner (2012). These calculated surface concentrations of nitrate precursors explain the distribution of fine nitrate particles illustrated in Fig. 1 and the region of formation where both $\mathrm{NH}_{3}$ and $\mathrm{HNO}_{3}$ concentrations are high. To enable comparison with Xu et Penner (2012), Fig. 5 shows the ratio of free ammonia $T_{\mathrm{A}}^{*}$ to total nitrate $T_{\mathrm{N}}$ (see Reaction 6 for the definition of $T_{\mathrm{A}}^{*}$ ). Regions with a negative ratio represent the regions where no excess ammonia is present either due to very low ammonia concentrations or high sulfates concentrations. In these regions, all the ammonia is used to neutralize the sulfates and form ammonium sulfate. At the surface, these regions are mostly encountered over the ocean or over the deserts and remote continental areas. Due to the short lifetime of ammonia (less than 1 day), these regions expand as altitude increases. In the middle troposphere, only small fine nitrate formation regions persist in convective and biomass burning areas subject to rapid upward transport of emissions. A ratio larger than 1 corresponds to regions where ammonia is abundant and hence the formation of nitrate is limited by the amount of nitric acid available. This condition is mostly met at the surface over regions with high ammonia concentrations, in northern Europe, the central US, India, China, and biomass burning regions. This is also the case over the ocean where natural oceanic $\mathrm{NH}_{3}$ emissions are present in a low $\mathrm{NO}_{\mathrm{x}}$ environment. In other regions (where the ratio is between 0 and 1), the formation of nitrate is limited by the amount of ammonia available. These results are in agreement with the findings of Xu and Penner (2012). 

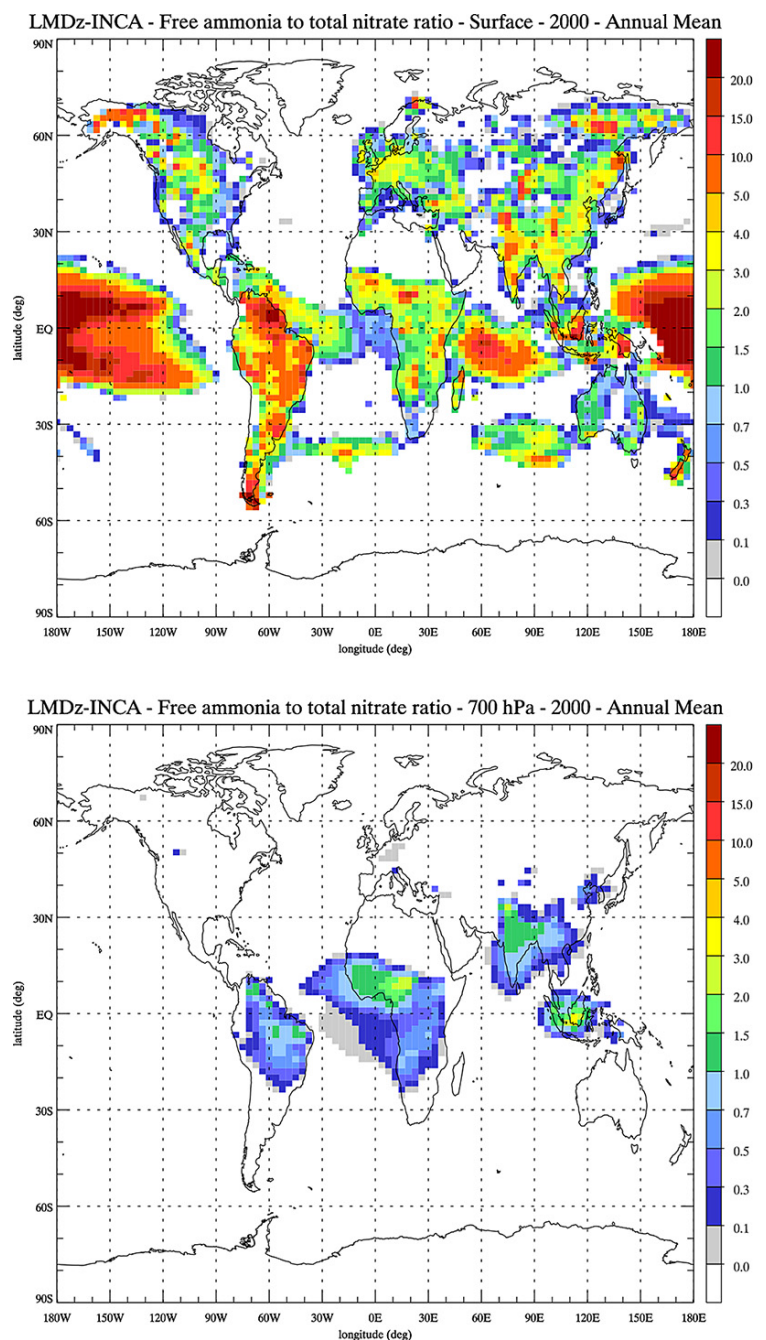
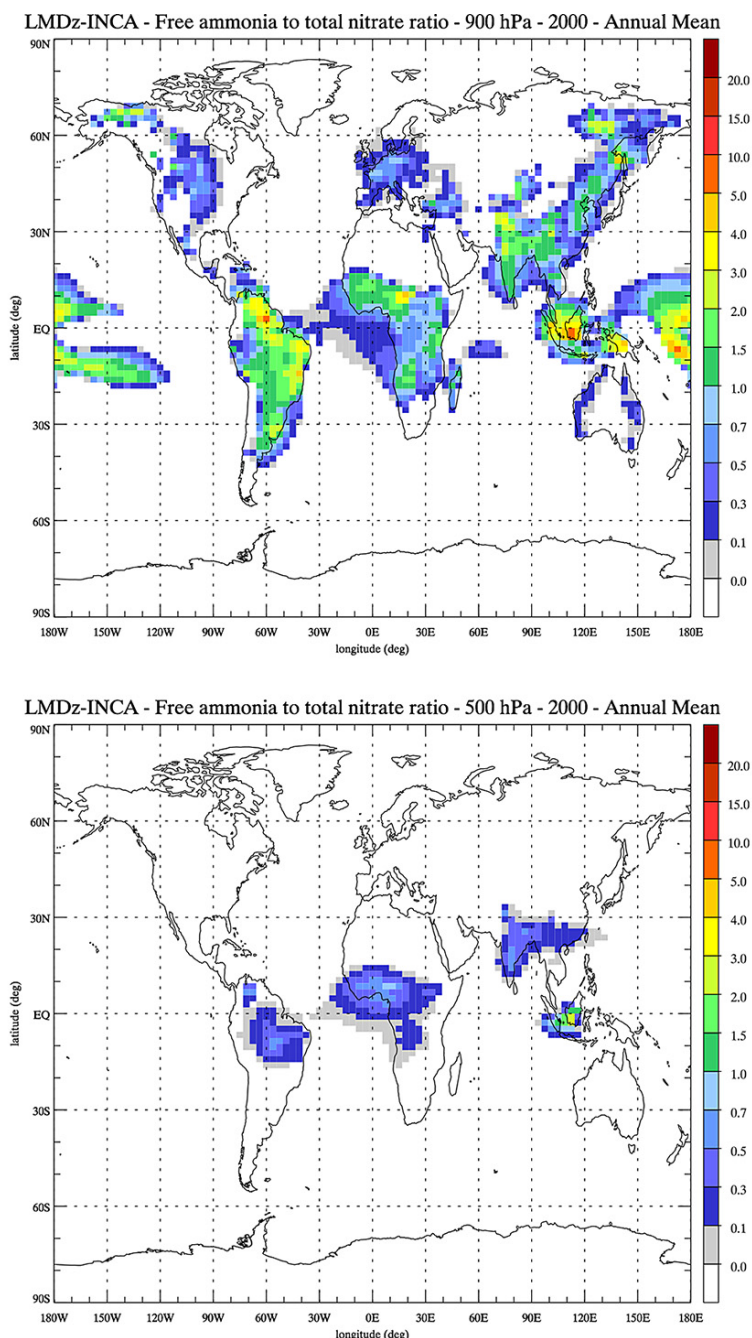

Figure 5. Ratio of annual mean free ammonia to total nitrate, calculated for present-day conditions at the surface, 900,700 , and $500 \mathrm{hPa}$.

Table 3 gives the global budget of nitric acid and nitrate particles for both the present-day (2000) and pre-industrial (1850) conditions. A similar budget has been presented by $\mathrm{Xu}$ and Penner (2012), and we refer to their study for the sake of comparison with our results. It should be mentioned though that Xu and Penner (2012) used a simplified nitrogen chemistry with fixed monthly mean fields of $\mathrm{OH}$ and $\mathrm{O}_{3}$ and without considering the role of organics on gas-phase nitrogen chemistry. For the present, we calculate a total source of $\mathrm{HNO}_{3}$ of $48.5 \mathrm{Tg} \mathrm{N} \mathrm{yr}^{-1}$ mostly arising $\left(44.6 \mathrm{Tg} \mathrm{N} \mathrm{yr}^{-1}\right)$ from the gas-phase reaction of $\mathrm{NO}_{2}$ with $\mathrm{OH}$. The heterogeneous formation of $\mathrm{HNO}_{3}$ from the reaction of $\mathrm{N}_{2} \mathrm{O}_{5}$ with sulfate aerosols contributes only $3.9 \mathrm{Tg} \mathrm{Nyr}^{-1}$ (or $8 \%$ ) of total nitric acid formation. This is in contrast to Xu and Penner (2012), who calculated a larger contribution of heterogeneous chemistry of $42 \%$. The reason for this disagreement is unclear. The fact that a simplified nitrogen chemistry that did not consider the role played by non-methane hydrocarbons was used in Xu and Penner (2012), as it was also the case in Bauer et al. (2004), is a possible cause for this difference. It is also unclear which types of aerosols were considered in $\mathrm{Xu}$ and Penner (2012) for $\mathrm{N}_{2} \mathrm{O}_{5}$ hydrolysis. In our model, only the hydrolysis on sulfate aerosols is considered (loss on other types of aerosols or cloud particles were not considered). Also, as pointed out by Evans and Jacob (2005), the impact of $\mathrm{N}_{2} \mathrm{O}_{5}$ hydrolysis on global chemistry is still uncertain and dependent on the accommodation coefficient used in the models. The accommodation coefficient varies among the various studies and could also explain this different in $\mathrm{HNO}_{3}$ heterogenous formation. The total loss of $\mathrm{HNO}_{3}$ reaches $49.5 \mathrm{Tg} \mathrm{N} \mathrm{yr}^{-1}$. The small unbalance between source and loss arises from the stratospheric input of nitric acid into the considered domain for this budget (up to 200hPa). Dry and wet deposition contribute about equally (respectively, 14.7 and $17.0 \mathrm{Tg} \mathrm{N} \mathrm{yr}^{-1}$ ) to the total nitric acid deposition loss, representing more than $60 \%$ of the total $\mathrm{HNO}_{3}$ loss. The total loss through nitrate formation totals $14.4 \mathrm{Tg} \mathrm{N} \mathrm{yr}^{-1}$. Nitric acid photolysis and reaction with 
Table 3. Tropospheric budget of nitric acid $\left(\mathrm{HNO}_{3}\right)$ and nitrate particles $\left(\mathrm{NO}_{3}^{-}\right)$for the pre-industrial (1850) and present-day (2000) simulations. The budget terms for $\mathrm{HNO}_{3}$ are integrated up to $200 \mathrm{hPa}$.

\begin{tabular}{|c|c|c|}
\hline & 1850 & 2000 \\
\hline \multicolumn{3}{|l|}{$\mathrm{HNO}_{3}$} \\
\hline Sources $\left(\mathrm{Tg} \mathrm{N}_{\mathrm{yr}}{ }^{-1}\right)$ & 14.09 & 48.51 \\
\hline Gas phase & 14.04 & 44.59 \\
\hline Aerosols & 0.05 & 3.92 \\
\hline $\operatorname{Loss}\left(\mathrm{Tg} \mathrm{N} \mathrm{yr}^{-1}\right)$ & 14.80 & 49.46 \\
\hline Gas phase & 1.55 & 3.42 \\
\hline Fine nitrates & 0.28 & 3.19 \\
\hline Dust nitrates & 2.96 & 6.26 \\
\hline Sea-salt nitrates & 1.57 & 4.92 \\
\hline Dry deposition & 3.42 & 14.66 \\
\hline Wet deposition & 5.02 & 17.02 \\
\hline Burden $(\operatorname{Tg~N})$ & 0.14 & 0.30 \\
\hline Lifetime (days) & 3.57 & 2.25 \\
\hline \multicolumn{3}{|l|}{$\mathrm{NO}_{3}^{-}$} \\
\hline Sources $\left(\mathrm{Tg} \mathrm{N}_{\mathrm{yr}}{ }^{-1}\right)$ & 4.81 & 14.37 \\
\hline Fine & 0.28 & 3.19 \\
\hline Dust & 2.96 & 6.26 \\
\hline Sea salt & 1.57 & 4.92 \\
\hline $\operatorname{Loss}\left(\mathrm{Tg} \mathrm{N} \mathrm{yr}^{-1}\right)$ & 4.80 & 14.33 \\
\hline Dry deposition & 0.32 & 1.66 \\
\hline Wet deposition & 4.49 & 12.67 \\
\hline Burden $(\operatorname{Tg} N)$ & 0.09 & 0.18 \\
\hline Fine & 0.01 & 0.05 \\
\hline Dust & 0.04 & 0.07 \\
\hline Sea salt & 0.03 & 0.06 \\
\hline Lifetime (days) & 6.75 & 4.61 \\
\hline
\end{tabular}

$\mathrm{OH}$ contribute $3.4 \mathrm{Tg} \mathrm{Nyr}^{-1}$. These terms are in line with $\mathrm{Xu}$ and Penner (2012) with a larger contribution of dry deposition in LMDz-INCA. The $\mathrm{HNO}_{3}$ tropospheric burden is $0.3 \mathrm{Tg} \mathrm{N}$, a value similar to Xu and Penner (2012), and the burden lifetime (burden divided by total loss rate) is 2.25 days in this model, to be compared to a burden lifetime of 2.59 days derived from their budget. Fine-mode ammonium nitrate formation constitutes $22 \%$ of the total source of nitrates $\left(14.4 \mathrm{Tg} \mathrm{N} \mathrm{yr}^{-1}\right)$ and the rest is from the formation of coarse nitrates on dust and sea salt. Most of the nitrate loss is caused by wet deposition $\left(12.7 \mathrm{Tg} \mathrm{N} \mathrm{yr}^{-1}\right)$. We calculate a total nitrate burden of $0.18 \mathrm{Tg} \mathrm{N}$, with $28 \%$ corresponding to the fine mode and the rest as coarse particles on dust and sea salt. The corresponding lifetime is 4.61 days. The burden of $\mathrm{NO}_{3}^{-}$in the troposphere has doubled since the pre-industrial, and its lifetime has decreased from a pre-industrial value of 6.75 days to its present-day value, reflecting the more efficient scavenging of accumulation-mode nitrate particles.

Table 4 summarizes the global budget of ammonia and ammonium. The only source of atmospheric $\mathrm{NH}_{3}$ is surface emissions, totaling $50.5 \mathrm{Tg} \mathrm{N} \mathrm{yr}^{-1}$ for the present-day.
Table 4. Tropospheric budget of ammonia $\left(\mathrm{NH}_{3}\right)$ and ammonium particles $\left(\mathrm{NH}_{4}^{+}\right)$for the pre-industrial (1850) and present-day (2000) simulations.

\begin{tabular}{|c|c|c|}
\hline & 1850 & 2000 \\
\hline \multicolumn{3}{|l|}{$\mathrm{NH}_{3}$} \\
\hline Sources: emissions $\left(\mathrm{Tg} \mathrm{N} \mathrm{yr}^{-1}\right)$ & 20.99 & 50.51 \\
\hline $\operatorname{Loss}\left(\mathrm{Tg} \mathrm{N} \mathrm{yr}^{-1}\right)$ & 20.98 & 50.47 \\
\hline Gas phase & 0.28 & 0.63 \\
\hline Ammonium formation & 5.14 & 17.46 \\
\hline Dry deposition & 9.67 & 21.33 \\
\hline Wet deposition & 5.89 & 11.05 \\
\hline Burden $(\operatorname{Tg} N)$ & 0.05 & 0.09 \\
\hline Lifetime (days) & 0.81 & 0.63 \\
\hline \multicolumn{3}{|l|}{$\mathrm{NH}_{4}^{+}$} \\
\hline Sources: ammonia conversion $\left(\mathrm{Tg} \mathrm{N} \mathrm{yr}^{-1}\right)$ & 5.14 & 17.46 \\
\hline Loss $\left(\mathrm{Tg} \mathrm{N} \mathrm{yr}^{-1}\right)$ & 5.13 & 17.42 \\
\hline Dry deposition & 0.32 & 2.50 \\
\hline Wet deposition & 4.81 & 14.91 \\
\hline Burden $(\operatorname{Tg} N)$ & 0.08 & 0.22 \\
\hline Lifetime (days) & 5.39 & 4.52 \\
\hline
\end{tabular}

The deposition of ammonia arises from dry $\left(11.0 \mathrm{Tg} \mathrm{N} \mathrm{yr}^{-1}\right)$ and wet deposition $\left(21.3 \mathrm{Tg} \mathrm{Nyr}^{-1}\right)$. The formation of ammonium sulfate and ammonium nitrate contributes 17.5 $\mathrm{Tg} \mathrm{N} \mathrm{yr}^{-1}(35 \%)$ to the total loss of $\mathrm{NH}_{3}$. The gas-phase chemistry oxidation of $\mathrm{NH}_{3}$ contributes a negligible amount to its loss. The loss of $\mathrm{NH}_{3}$ through this oxidation pathway is, however, a source of $\mathrm{N}_{2} \mathrm{O}$ for roughly a similar amount of $0.6 \mathrm{Tg} \mathrm{Nyr}^{-1}$. This number is similar to the estimate by Dentener and Crutzen (1994), who estimated a source of $0.6 \mathrm{Tg} \mathrm{N} \mathrm{yr}^{-1}$ with an uncertainty range of $0.4-1.2 \mathrm{Tg} \mathrm{N}$, and it represents about $10 \%$ of the anthropogenic source of $\mathrm{N}_{2} \mathrm{O}$ as pointed out by these authors. This value is also in the range of $0-1.6 \mathrm{Tg} \mathrm{N}$ estimated by Lee et al. (1997). The burden of $\mathrm{NH}_{3}$ has increased from $0.05 \mathrm{Tg} \mathrm{N}$ in the pre-industrial to $0.09 \mathrm{Tg} \mathrm{N}$ for the present-day. The corresponding presentday lifetime of ammonia in the atmosphere is 0.63 days. The only source of $\mathrm{NH}_{4}^{+}$is ammonium sulfate and ammonium nitrate formation $\left(17.5 \mathrm{Tg} \mathrm{N} \mathrm{yr}^{-1}\right)$. The loss arises mostly from wet deposition $\left(14.9 \mathrm{Tg} \mathrm{Nyr}^{-1}\right)$ and to a lesser extent from surface dry deposition $\left(2.5 \mathrm{Tg} \mathrm{N} \mathrm{yr}^{-1}\right)$. The burden of $\mathrm{NH}_{4}^{+}$ is $0.22 \mathrm{Tg} \mathrm{N}$ with a lifetime of 4.52 days in the atmosphere.

\subsection{Surface deposition}

In Fig. 6 we present the total (dry plus wet) annual deposition of $\mathrm{SO}_{\mathrm{x}}\left(=\mathrm{SO}_{2}+\mathrm{SO}_{4}^{=}\right), \mathrm{NH}_{\mathrm{x}}\left(=\mathrm{NH}_{3}+\mathrm{NH}_{4}^{+}\right)$, and $\mathrm{NO}_{\mathrm{y}}$ $\left(=\mathrm{NO}+\mathrm{NO}_{2}+\mathrm{NO}_{3}+\mathrm{HNO}_{2}+\mathrm{HNO}_{3}+\mathrm{HNO}_{4}+2 \mathrm{~N}_{2} \mathrm{O}_{5}\right.$ + PAN + organic nitrates + particulate $\mathrm{NO}_{3}^{-}$). The three plots show similar patterns, with high deposition over North America, Europe, India, and China. The total $\mathrm{SO}_{\mathrm{x}}$ deposition is $107 \mathrm{Tg} \mathrm{S} \mathrm{yr}^{-1}$, with wet deposition contributing 

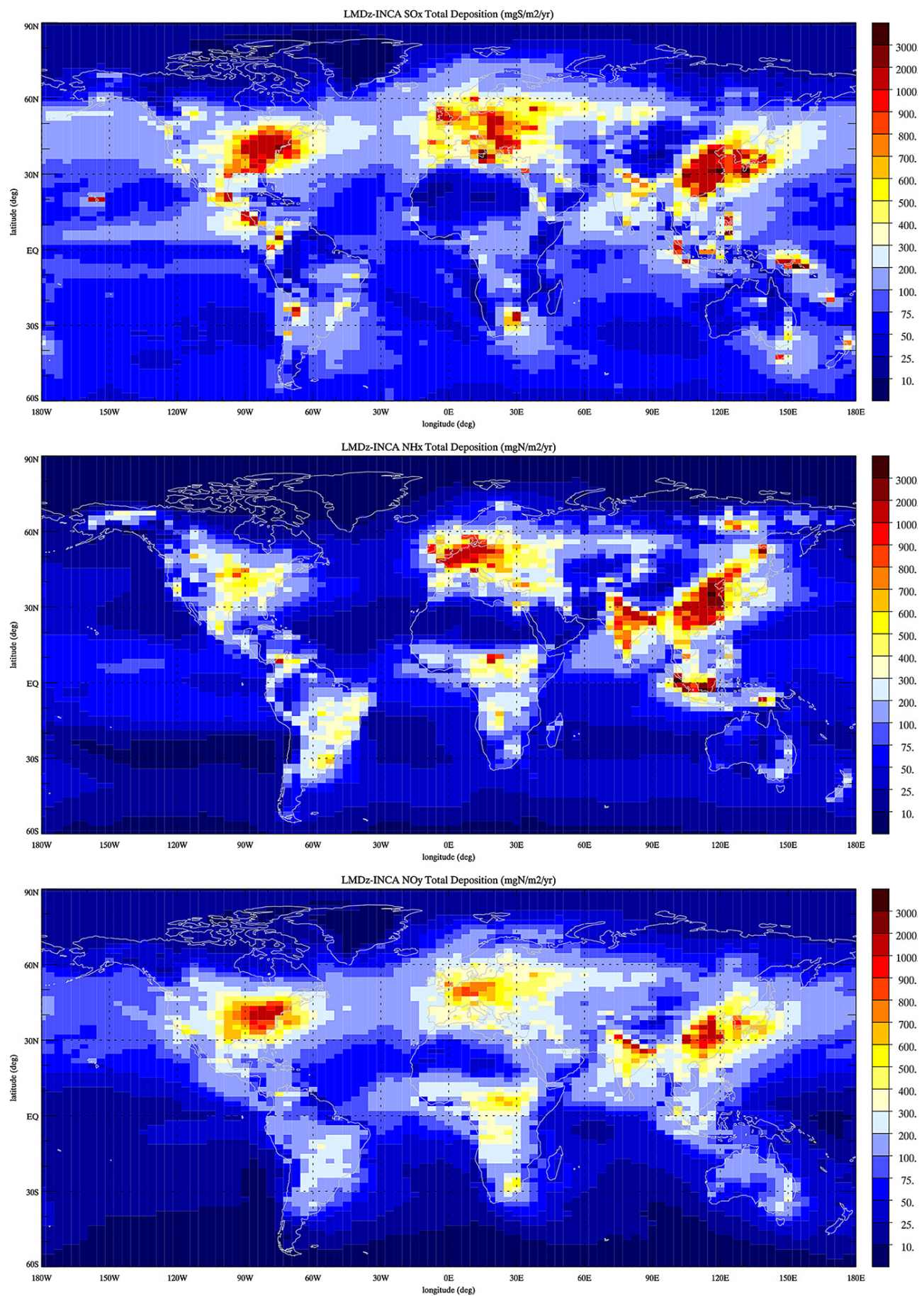

Figure 6. Annual mean $\mathrm{SO}_{\mathrm{x}}\left(\mathrm{mg} \mathrm{S} \mathrm{m}^{-2} \mathrm{yr}^{-1}\right), \mathrm{NH}_{\mathrm{x}}$, and $\mathrm{NO}_{\mathrm{y}}\left(\mathrm{mg} \mathrm{N} \mathrm{m}^{-2} \mathrm{yr}^{-1}\right)$ total surface deposition calculated for present-day conditions.

$75 \%$ to this total. The maximum sulfur deposition reaches $5 \mathrm{~g} \mathrm{~S} \mathrm{~m}^{-2} \mathrm{yr}^{-1}$ in northern China. Over North America a maximum deposition reaching $1-2 \mathrm{~g} \mathrm{~S} \mathrm{~m}^{-2} \mathrm{yr}^{-1}$ is calculated over the eastern United States. In western Europe, the deposition ranges from $500 \mathrm{mg} \mathrm{S} \mathrm{m}^{-2} \mathrm{yr}^{-1}$ in the south to about $2 \mathrm{~g} \mathrm{~S} \mathrm{~m}^{-2} \mathrm{yr}^{-1}$ in the north, values reached over the United Kingdom. A maximum deposition reaching $2 \mathrm{~g} \mathrm{~S} \mathrm{~m}^{-2} \mathrm{yr}^{-1}$ is calculated in central Europe. The global $\mathrm{NH}_{\mathrm{x}}$ deposition is close to $50 \mathrm{Tg} \mathrm{Nyr}{ }^{-1}$, with wet and dry deposition contributing each $50 \%$ to this total (see Table 3). The total ammonia deposition reaches maximum values of $2-3 \mathrm{~g} \mathrm{~N} \mathrm{~m}^{-2} \mathrm{yr}^{-1}$ over northern Europe and northern India 
and more than $5 \mathrm{~g} \mathrm{~N} \mathrm{~m}^{-2} \mathrm{yr}^{-1}$ in China. Over North America, a maximum deposition reaching $800 \mathrm{mg} \mathrm{N} \mathrm{m}^{-2} \mathrm{yr}^{-1}$ is calculated over the central United States. The total oxidized nitrogen deposition totals $50 \mathrm{Tg} \mathrm{N} \mathrm{yr}^{-1}$, with wet deposition contributing $60 \%$ to this term. Interestingly, total $\mathrm{NH}_{\mathrm{x}}$ and total $\mathrm{NO}_{\mathrm{y}}$ contribute the same amount to the global nitrogen deposition to the surface ecosystems. The total $\mathrm{NO}_{\mathrm{y}}$ deposition shows a slightly different pattern from the other deposition terms, with a maximum reaching $1.5 \mathrm{~g} \mathrm{~N} \mathrm{~m}^{-2} \mathrm{yr}^{-1}$ over the eastern United States, northern India, and China. In Europe, the $\mathrm{NO}_{\mathrm{y}}$ deposition reaches $800-900 \mathrm{mg} \mathrm{N} \mathrm{m}^{-2} \mathrm{yr}^{-1}$. These distributions are in good agreement with the total deposition illustrated by Dentener et al. (2006b) and resulting from the ensemble mean of 23 atmospheric models and with the distributions illustrated by Lamarque et al. (2013) for the ACCMIP simulations.

Table 2 summarizes the comparison of the wet deposition of these three terms calculated by the model with the measurements from the EMEP network over Europe, from the NADP network over North America and from the EANET network over eastern Asia (see Supplement for individual plots). The sulfate deposition is slightly underestimated by the model with a normalized mean bias (NMB) of $-27 \%$ in Europe and $-20 \%$ in North America. In eastern Asia, a higher underestimation is obtained (NMB $=-80 \%)$. A similar disagreement in eastern Asia was also obtained by Dentener et al. (2006b) and by Lamarque et al. (2013) and tentatively attributed to unaccounted sources of $\mathrm{SO}_{2}$ from coal burning in China. The wet deposition of $\mathrm{NH}_{\mathrm{x}}$ is well represented in Europe (NMB $=-4.5 \%)$ and to a lesser extent in North America $(\mathrm{NMB}=-32 \%)$. We note however that the deposition term is again significantly underestimated in eastern Asia $(\mathrm{NMB}=-60 \%)$. The wet deposition of oxidized nitrogen from $\mathrm{HNO}_{3}+\mathrm{NO}_{3}^{-}$is relatively well represented in Europe but underestimated by $-28 \%$. Over North America, a better comparison is obtained $(\mathrm{NMB}=+13 \%)$. Again, in eastern Asia, a significant underestimate of the wet deposition is obtained ( $\mathrm{NMB}=-54 \%$ ). Work is underway in order to better understand the reason for the significant underestimate of the deposition terms in eastern Asia and in particular in China based on new emission inventories generated for this region (Wang et al., 2012).

\subsection{Aerosol optical properties and radiative forcings}

The aerosol optical depth and direct radiative forcings of the various aerosol components are calculated online by the general circulation model. The solar radiation code in the LMDz GCM consists of an improved version of the parameterizations of Fouquart and Bonnel (1980). The shortwave spectrum is divided into two intervals: $0.25-0.68 \mu \mathrm{m}$ and 0.68 $4.00 \mu \mathrm{m}$. The model accounts for the diurnal cycle of solar radiation and allows fractional cloudiness to form in a grid box. The radiative fluxes are computed every $2 \mathrm{~h}$, at the top of the atmosphere and at the surface, with and without the presence of clouds. The clear-sky and all-sky direct radiative forcings of the various aerosol components are finally obtained by subtracting the 1850 radiative fluxes from the considered simulation. Since we focus this study on direct aerosol forcings, the cloudiness is not affected by the presence of aerosols in this version of the model.

Figure 7 shows the calculated total aerosol optical depth at $550 \mathrm{~nm}$ and the optical depth associated with fine and coarse nitrate particles. The total aerosol optical depth (AOD) exhibits values of $0.15-0.25$ over the eastern United States and Europe, associated mostly with pollution aerosols. Maximum values reaching more than 0.5 and associated with dust aerosols are calculated over northern Africa, Saudi Arabia, and China. In China, both natural and pollution aerosols contribute to the high aerosol optical depth. Distributions very similar to these results have also been presented in other studies (e.g., Kinne et al., 2006; Bellouin et al., 2011; Xu and Penner, 2012; Shindell et al., 2013). The global mean and total AOD is 0.135 , with accumulation-mode particles contributing 0.059 to AOD. As expected from the burden shown in Figure 3, nitrates exhibit higher optical depth over source regions: values of $0.02-0.03$ over the central United States, maximum optical depth of 0.05 in northern Europe, and more than 0.1 in northern China. The contribution of nitrates formed from biomass burning emissions is also visible in South America, Africa, and Indonesia, with values reaching 0.1 in the later region. The nitrate optical depth is in good agreement with the results presented by Myhre et al. (2006) regarding both the general patterns of the distribution and the calculated values. The global mean and total nitrate optical depth is 0.0053 . Fine nitrate particles contribute 0.0048 to this total number. The evaluation of the calculated total AOD by comparing with the measurements from the Aerosol Robotic Network (AERONET) network (Holben et al., 2001, Kinne et al., 2006) is summarized in Table 2 (see Supplement for individual plots). Matching daily data from the model and AERONET were aggregated to monthly averages. Worldwide, the measured and modeled AOD show a relatively good correlation $(R=0.57)$. The arithmetic mean for the measurements of 0.226 is, however, underestimated by the modeled values of 0.202 with a normalized mean bias (NMB) of $-11 \%$. A good agreement with the AERONET measurements is obtained over North America. Over this region, the model slightly underestimates the measurements (NMB $=-4.5 \%, R=0.77$ ). Over Africa, higher AOD associated with dust aerosols are calculated. A fairly good correlation is reached $(R=0.66)$, also with a light underestimate by the model of $-10 \%$. Over eastern Asia, the model underestimates the AOD (NMB $=-39 \%)$. Over Europe, a fairly good correlation between model and measurement is obtained $(R=0.58)$. However, over this region, the model overestimates the measurements $(\mathrm{NMB}=+6 \%)$.

Figure 8 shows the zonal nitrate column and the corresponding optical depth at $550 \mathrm{~nm}$. This figure illustrates both the fine and coarse-mode components for the two variables. 

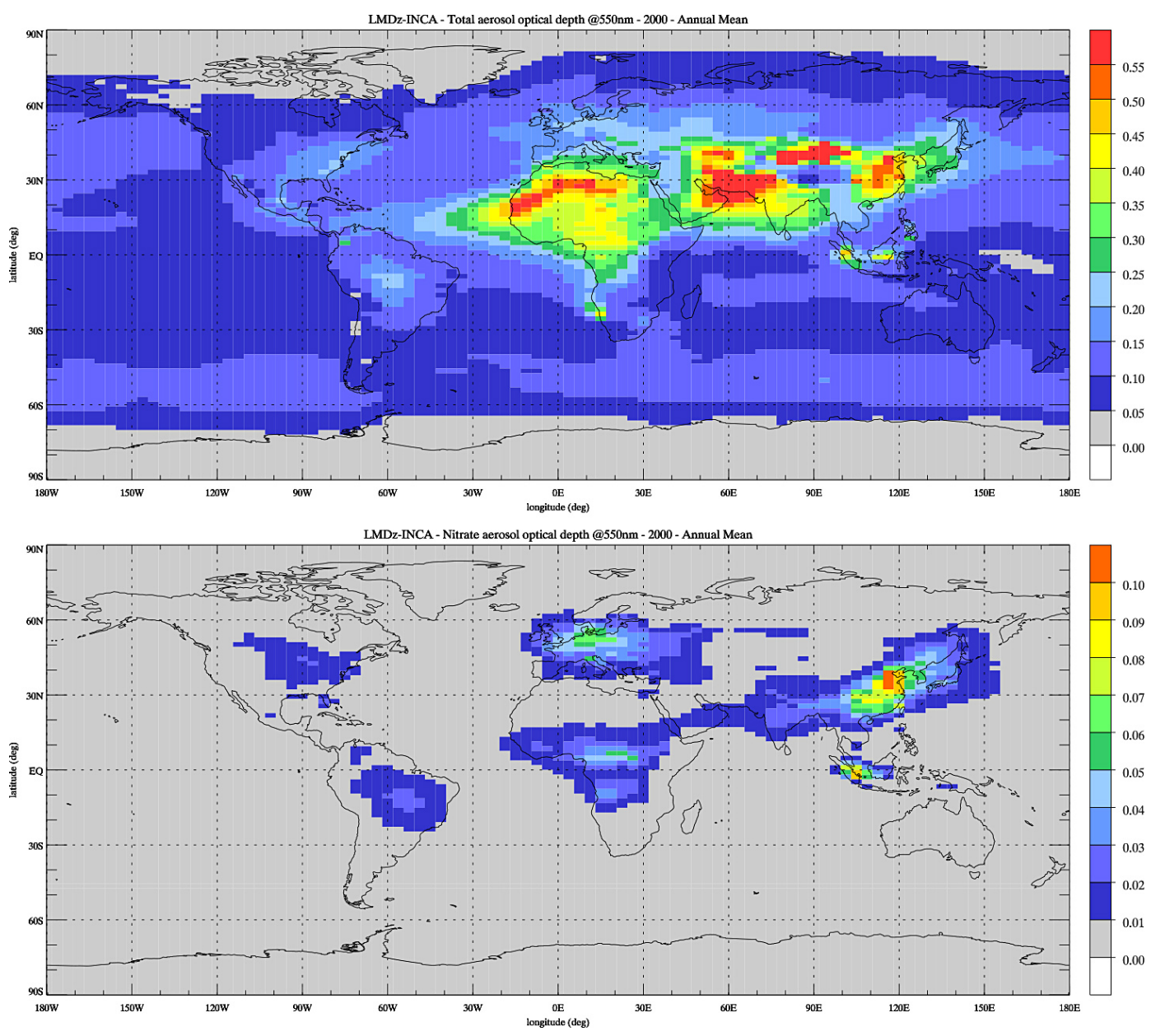

Figure 7. Annual mean total aerosol optical depth at $550 \mathrm{~nm}$ (top), and nitrate aerosol optical depth (bottom) simulated for present-day conditions.

The total zonal mean nitrate aerosol column peaks in the northern hemisphere around $25-50^{\circ}$, as shown already in Fig. 3. Coarse particles dominate the zonal mean nitrate burden and reach $2.5 \mathrm{mg} \mathrm{m}^{-2}$. These particles are also responsible for a background column of $0.5-0.8 \mathrm{mg} \mathrm{m}^{-2}$ in remote areas, associated mainly with coarse nitrate particles on sea salt. Fine particles associated with pollution present a maximum of about $1 \mathrm{mg} \mathrm{m}^{-2}$ at $40^{\circ} \mathrm{N}$ and a secondary maximum of about $0.5 \mathrm{mg} \mathrm{m}^{-2}$ associated with biomass burning emissions around the Equator. The zonal mean nitrate optical depth shows the opposite behavior since coarse particles contribute less efficiently to the Mie scattering. The total zonal mean nitrate optical depth reaches more than 0.012 around $40^{\circ} \mathrm{N}$. This optical depth is largely associated with fine particles with coarse nitrates contributing a maximum optical depth of about $2 \times 10^{-3}$.

Figure 9 gives the direct radiative forcings of aerosols since pre-industrial times calculated at the top of the atmosphere for all-sky conditions. The forcings are calculated as the difference between the present-day and pre-industrial aerosol distributions. The global mean sulfate radiative forcing is $-0.315 \mathrm{~W} \mathrm{~m}^{-2}$, a value in agreement with the recent intercomparison of models provided in the framework of AeroCom by Myhre et al. (2013) indicating a mean forcing of $-0.32 \pm 0.11 \mathrm{~W} \mathrm{~m}^{-2}$ and with the most probable range of -0.18 to $-0.44 \mathrm{~W} \mathrm{~m}^{-2}$ provided by Shindell et al. (2013). The forcing shows values of $-2 \mathrm{~W} \mathrm{~m}^{-2}$ over regions of high sulfate load over the eastern United States, southern Europe, and eastern Asia. The global mean radiative forcing associated with black carbon (BC) particles including the fossil fuel, biofuel, and biomass burning components is equal to $0.19 \mathrm{~W} \mathrm{~m}^{-2}$. Over the southeastern United states and the United Kingdom, the negative forcing indicates that $\mathrm{BC}$ emissions have decreased in these regions since the reference year of 1850 already included emissions from biofuel and to a lesser extent, coal burning. The organic carbon (OC) forcing is $-0.056 \mathrm{~W} \mathrm{~m}^{-2}$. The forcing is negative except in regions where emissions have decreased, as mentioned for BC. Myhre et al. (2013) reported a radiative forcing arising from fossil fuel and biofuel of $+0.18 \pm 0.07 \mathrm{~W} \mathrm{~m}^{-2}$ for 

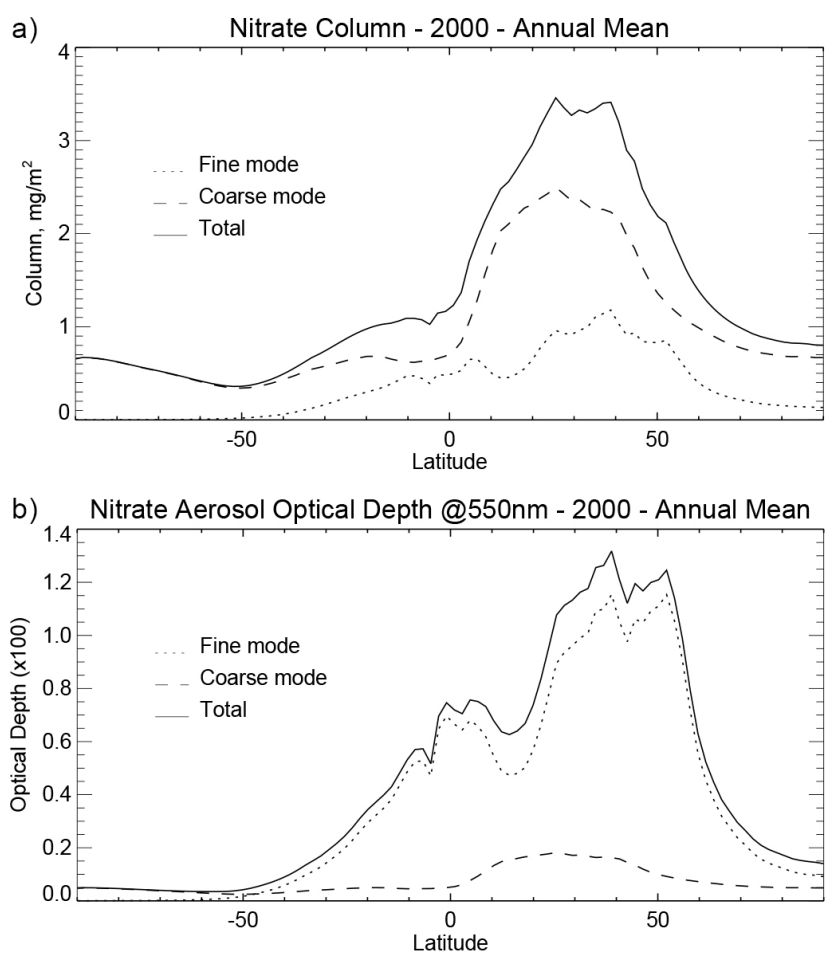

Figure 8. Zonal and annual mean total (solid line), coarse-mode (dashed line), and fine-mode (dotted line) nitrate particles column $\left(\mathrm{mg} \mathrm{m}^{-2}\right)$ (a); corresponding total, coarse, and fine nitrate particles optical depth at $550 \mathrm{~nm}(\times 100)(\mathbf{b})$.

$\mathrm{BC},-0.03 \pm 0.01 \mathrm{~W} \mathrm{~m}^{-2}$ for $\mathrm{OC}$, and a combined $\mathrm{BC}+\mathrm{OC}$ forcing from biomass burning of $-0.00 \pm 0.05 \mathrm{~W} \mathrm{~m}^{-2}$. The calculated forcings for $\mathrm{BC}$ and $\mathrm{OC}$ with this model are in agreement with this compilation and with Shindell et al. (2013). The calculated global mean forcing for nitrate particles is $-0.056 \mathrm{~W} \mathrm{~m}^{-2}$. Fine nitrate particles contribute $-0.049 \mathrm{~W} \mathrm{~m}^{-2}$ to this forcing and anthropogenic coarse nitrate particulate matter only $-0.006 \mathrm{~W} \mathrm{~m}^{-2}$. The total nitrate forcing reaches $-2.6 \mathrm{~W} \mathrm{~m}^{-2}$ over China, $-1.0 \mathrm{~W} \mathrm{~m}^{-2}$ over northern Europe, and $-0.5 \mathrm{~W} \mathrm{~m}^{-2}$ over the central United States. The nitrate forcing also reaches more than $-1.0 \mathrm{~W} \mathrm{~m}^{-2}$ over biomass burning regions. For this forcing, Myhre et al. (2013) reported a global value of $-0.08 \pm 0.04 \mathrm{~W} \mathrm{~m}^{-2}$ and Shindell et al. (2013), a value of $-0.19 \pm 0.18 \mathrm{~W} \mathrm{~m}^{-2}$. There is a significant spread in the calculated nitrate forcings from the various models, ranging from a value of $-0.02 \mathrm{~W} \mathrm{~m}^{-2}$ with the Oslo CTM2 to $-0.12 \mathrm{~W} \mathrm{~m}^{-2}$ with the GEOS-CHEM model (Myhre et al., 2013), and even to $-0.41 \mathrm{~W} \mathrm{~m}^{-2}$ with the GISS model (Shindell et al., 2013). The value calculated with this model is in the range provided by this previous work. Additional work is required to understand the reason for the spread in the various model estimates. In particular, the role played by coarse nitrate formation is important since it subtracts $\mathrm{HNO}_{3}$ from the gas phase, decreasing the formation of fine particles of ammonium nitrates and hence reducing the total forcing of nitrates particles.

\section{Future evolution of nitrate aerosols}

In this section, we present the future evolution of nitrate aerosols under the various RCP scenarios for the years of 2030, 2050, and 2100. The associated direct radiative forcings are presented and the nitrate forcing compared to the forcing of the other particles in order to investigate their relative contribution in the future. Snapshot simulations have been performed for these various cases as described in Sect. 2.3, and the global emissions for key species related to nitrate formation have been presented in Table 1. In order to better understand the contribution of $\mathrm{NH}_{3}, \mathrm{NO}_{\mathrm{x}}$, and $\mathrm{SO}_{2}$ emissions to future nitrate levels, sensitivity simulations have been performed in the particular case of the RCP4.5 scenario for the year 2100 .

\subsection{Atmospheric composition}

The four RCP scenarios have been simulated with the model but, as far as nitrate particles and their radiative forcing are concerned, and as visible from the total emissions presented in Table 1, two particular scenarios are interesting to compare. In all scenarios, $\mathrm{SO}_{2}$ and $\mathrm{BC}$ emissions decrease from their present-day value to their 2100 level. Despite significant differences in 2030 and 2050 (in particular in the case of $\mathrm{SO}_{2}$ emissions), the level reached in 2100 in the four emission scenarios are often close to each other for these species. This is not the case for two important precursors of nitrate particles: ammonia and nitrogen oxides. For $\mathrm{NH}_{3}$ and $\mathrm{NO}_{\mathrm{x}}$, RCP4.5 and RCP8.5 represent the extremes for emissions in 2100 and are expected to lead to very different nitrate levels in the future. This is particularly the case for $\mathrm{NH}_{3}$ emissions, which remain close to their present-day level $(51 \mathrm{Tg} \mathrm{N})$ in 2100 in the RCP4.5 scenario ( $54 \mathrm{Tg} \mathrm{N}$ ), but increase by $50 \%$ in 2100 in RCP8.5 (78 Tg N). For $\mathrm{NO}_{\mathrm{x}}$, emissions decrease from $46 \mathrm{Tg} \mathrm{N}$ in the present-day to $24 \mathrm{Tg} \mathrm{N}$ in 2100 in RCP4.5 but decrease only to $31 \mathrm{Tg} \mathrm{N}$ in 2100 in RCP8.5.

As a consequence of these changes in emissions, the concentration of $\mathrm{NH}_{3}$ varies quite significantly in the future between these two extreme scenarios (see Supplement for additional figures on future changes of the key atmospheric constituents). For surface $\mathrm{NH}_{3}$ concentrations, in scenario RCP8.5, a significant increase is calculated everywhere in 2030 and 2100 except in Indonesia, where biomass burning emissions are reduced. In the central United States, northern and central Europe, India, and China, $\mathrm{NH}_{3}$ increases by up to $2 \mu \mathrm{g} \mathrm{m}^{-3}$ in 2100 compared to the reference levels illustrated in Fig. 4. In the RCP4.5 scenario, a significant increase is still predicted in India and in China where emissions are still predicted to rise. However, concentrations are significantly reduced in western and eastern Europe by up to $1 \mu \mathrm{g} \mathrm{m}^{-3}$ and 

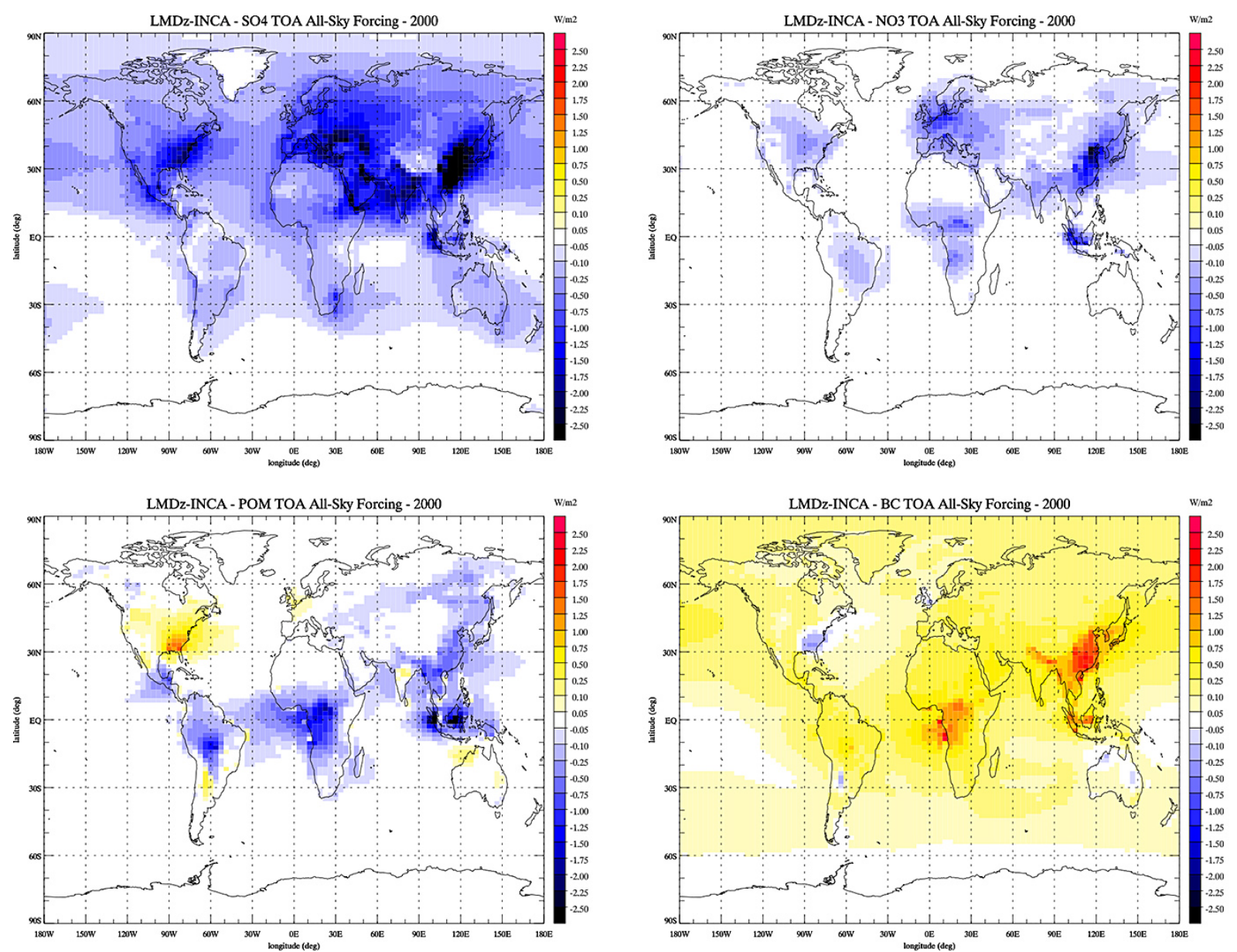

Figure 9. All-sky, top-of-the-atmosphere direct radiative forcing of sulfates, nitrates, organic carbon, and black carbon particles $\left(\mathrm{W} \mathrm{m}^{-2}\right.$ ) calculated for present-day conditions.

a lesser decrease of $0.5-1 \mu \mathrm{g} \mathrm{m}^{-3}$ is calculated in the central US. Due to a reduction in $\mathrm{NO}_{\mathrm{x}}$ emissions, $\mathrm{HNO}_{3}$ has already significantly decreased in 2030 in North America and Europe in both scenarios. In contrast, a strong increase is calculated in India and in China reaching more than $2 \mu \mathrm{g} \mathrm{m}^{-3}$ in 2030. In 2100, the $\mathrm{HNO}_{3}$ reduction is almost consistent over the continents with the exception of biomass burning regions in Africa and India in the case of RCP8.5. The concentration of $\mathrm{SO}_{4}=$ increases in India and Southeast Asia by more than $2 \mu \mathrm{g} \mathrm{m}^{-3}$ in 2030. As expected from the sharp decrease in $\mathrm{SO}_{2}$ emissions, at the end of the 21st century, a general decrease of the surface concentration is calculated in 2100, reaching more than $2 \mu \mathrm{g} \mathrm{m}^{-3}$ in North America, Europe, and China.

As a result of these changes in nitrate precursor surface concentrations, nitrate particles are expected to undergo significant variations in the future. Figure 10 shows the evolution of nitrate particles surface concentrations for the various simulations performed and averaged over several regions of the world. As shown earlier (Fig. 1), present-day nitrate concentrations are higher in Europe $\left(1.4 \mu \mathrm{g} \mathrm{m}^{-3}\right.$ than in North
America $\left(0.35 \mu \mathrm{g} \mathrm{m}^{-3}\right)$. Due to the decrease in precursors, the concentrations in these two regions decrease in all scenarios during the 21 st century. By 2100 , the mean surface concentration in Europe is in the range of $0.14-0.43 \mu \mathrm{g} \mathrm{m}^{-3}$ and in the range of $0.03-0.15 \mu \mathrm{g} \mathrm{m}^{-3}$ in North America. In northern and southern Asia, the concentration increases significantly in 2030 and 2050 in scenarios RCP6.0 and RCP8.5, reaching $3.6 \mu \mathrm{g} \mathrm{m}^{-3}$. By 2100 , the surface concentration is in the range of $0.38-0.78 \mu \mathrm{g} \mathrm{m}^{-3}$ and $0.01-0.51 \mu \mathrm{g} \mathrm{m}^{-3}$ in northern and southern Asia, respectively. In India, the surface nitrate concentration increases until 2050 in most scenarios, reaching $1.45 \mu \mathrm{g} \mathrm{m}^{-3}$ on average. The concentration then decreases and is in the range of $0.27-0.65 \mu \mathrm{g} \mathrm{m}^{-3}$ in 2100 . The concentration of nitrates in other regions (Africa, South America, Australia) show little variation from their presentday value (not shown). The global nitrate concentration in-

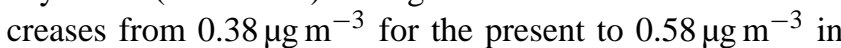
2030 and decreases to $0.10-0.21 \mu \mathrm{g} \mathrm{m}^{-3}$ in 2100 .

Figure 11 shows the ratio of free ammonia $\left(T_{\mathrm{A}}^{*}\right)$ to total nitrate $\left(T_{\mathrm{N}}\right)$ for the year 2100 and scenario RCP8.5. There is a significant increase in this ratio at the surface and in 

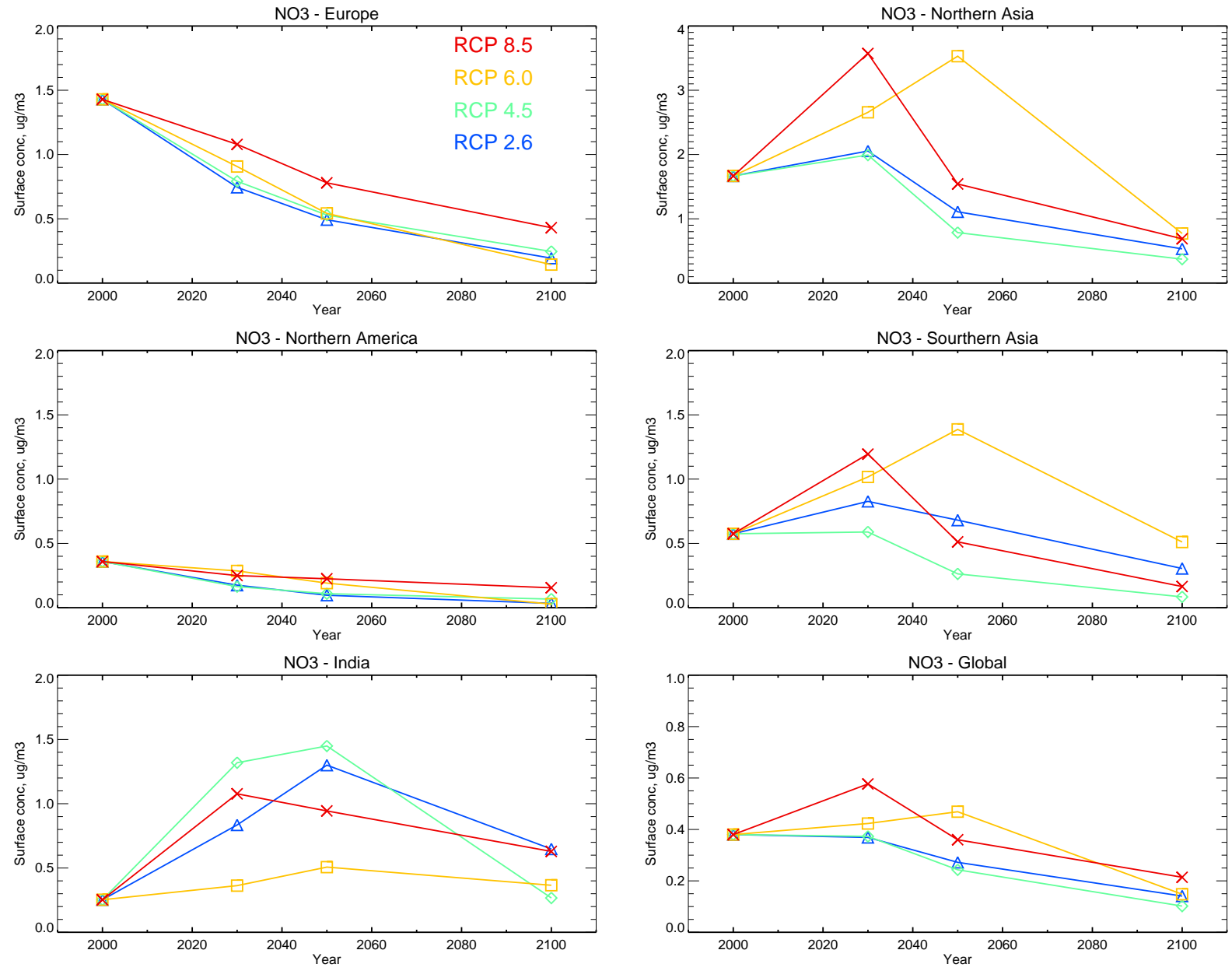

Figure 10. Evolution of the surface nitrate concentration $\left(\mu \mathrm{g} \mathrm{m}^{-3}\right.$ ) in scenarios RCP8.5 (red), RCP6.0 (yellow), RCP4.5 (green), and RCP2.6 (blue) between present-day and 2100. The averaged surface concentration is depicted for Europe, North America, northern Asia, southern Asia, India, and the entire globe.

the free troposphere compared to the reference simulation (Fig. 5). At the surface, negative ratios indicating the formation of ammonium sulfate instead of ammonium nitrate have vanished over the continents due to a significant and general reduction in $\mathrm{SO}_{4}^{=}$concentrations. The ratio has also increased over the continents to values generally larger than 1 , indicating an increased excess of ammonia relative to nitric acid, and a stronger limitation of particle formation by $\mathrm{HNO}_{3}$ concentrations. This is a direct consequence of lower $\mathrm{HNO}_{3}$ and higher $\mathrm{NH}_{3}$ concentrations in 2100. Interestingly, in the free troposphere, the $T_{\mathrm{A}}^{*} / T_{\mathrm{N}}$ ratio becomes positive in the northern hemisphere due to decreased sulfate concentrations. As a consequence, nitrate particles form at higher altitudes, mostly limited by the amount of $\mathrm{NH}_{3}$ present at these altitudes.

As discussed above, the change in nitrate precursors is responsible for a strong increase of the nitrate column in the northern hemisphere (see Supplement). In both RCP8.5 and RCP4.5 scenarios, the increase in the nitrate column is more than compensated by strong decreases in surface concentrations over Europe and China in 2030 and 2100 (Fig. 10), and over these regions the column decreases by up to $2 \mathrm{mg} \mathrm{m}^{-2}$. In the case of RCP4.5, this also holds over the central US, with a decrease of the column reaching $0.4 \mathrm{mg} \mathrm{m}^{-2}$. In scenario RCP8.5, in 2100, it is interesting to note that the nitrate column also increases in the Southern Hemisphere mostly associated with transport from source regions in Africa and South America. Figure 12 and Table 5 present the evolution in the global burden of nitrate particles and its main precursors for the various scenarios and time slice experiments. In all scenarios, the burden of fine nitrate particles increases in the atmosphere from a present-day value of 0.05 to $0.13 \mathrm{Tg} \mathrm{N}$ for RCP8.5 and $0.07 \mathrm{Tg} \mathrm{N}$ for RCP4.5. As expected, these two extreme values are mainly driven by the change in $\mathrm{NH}_{3}$ emissions and burden. The burden of $\mathrm{NH}_{3}$ increases from its present-day value of $0.09 \mathrm{Tg} \mathrm{N}$ to a maximum value of $0.23 \mathrm{TgN}$ in 2100 in the case of RCP8.5 and to a minimum value of $0.14 \mathrm{Tg} \mathrm{N}$ for RCP4.5. The formation of coarse 

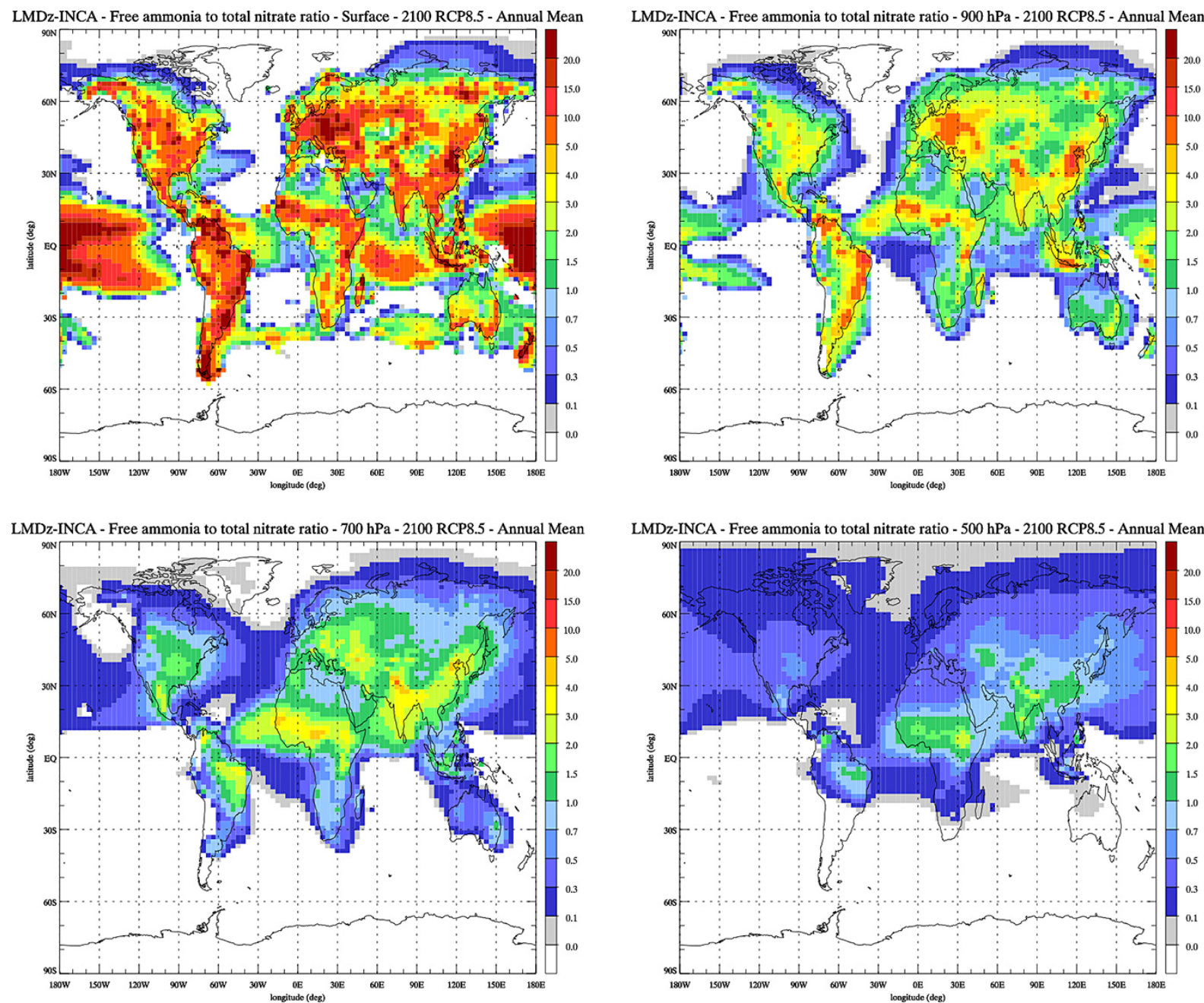

Figure 11. Ratio of annual mean free ammonia to total nitrate, calculated for $2100 \mathrm{RCP} 8.5$ conditions at the surface, 900,700 , and $500 \mathrm{hPa}$.

nitrate on dust and sea salt is a result of $\mathrm{HNO}_{3}$ heterogeneous uptake on these particles. Since no change in climate is considered in these simulations, the burden of dust and sea-salt particles is similar in all simulations. Therefore, the evolution of the coarse nitrate particle burden follows the evolution of nitric acid in the atmosphere, and decreases from 0.13 to $0.09-0.12 \mathrm{Tg} \mathrm{N}$ in 2100 . Overall, the burden of total nitrate particles increases from 0.181 to $0.183 \mathrm{Tg} \mathrm{N}$ in 2100 in the case of RCP4.5 and to $0.247 \mathrm{Tg} \mathrm{N}$ in the case of RCP8.5. The relative contribution of fine particles to this total is, however, modified and increased from a present-day value of $28 \%$ to $40 \%$ in 2100 for RCP4.5 and to $51 \%$ for RCP8.5. Since fine particles contribute the most to the nitrate optical depth and radiative forcing, this feature will have consequences on the climate impact of these particles. The future decrease in sulfates leading less ammonium sulfate formation is partially compensated by an increase in ammonia and formation of ammonium nitrate. As a consequence, the $\mathrm{NH}_{4}^{+}$global bur- den remains fairly constant in time and varies from a presentday value of $0.21 \mathrm{Tg} \mathrm{N}$ to $0.17-0.24 \mathrm{Tg} \mathrm{N}$ in 2100 .

\subsection{Sensitivity to $\mathrm{NH}_{3}, \mathrm{NO}_{\mathrm{x}}$, and $\mathrm{SO}_{2}$ emissions}

As discussed earlier, as a direct consequence of future changes in nitrate precursors, scenarios RCP8.5 and RCP4.5 represent the two extremes as far as future nitrates concentrations are concerned. Indeed, $\mathrm{SO}_{2}$ emissions are close in both scenarios, but $\mathrm{NO}_{\mathrm{x}}$ and to a larger extent $\mathrm{NH}_{3}$ emissions are significantly different and at the extremes of their future evolution. Three sensitivity experiments have been performed in order to investigate the relative importance of these emissions on the future nitrate levels. These sensitivity studies have been derived from scenario RCP4.5 for 2100 in order to better understand the role played by $\mathrm{SO}_{2}, \mathrm{NO}_{\mathrm{x}}$, and $\mathrm{NH}_{3}$ emissions on the differences obtained between RCP4.5 and RCP8.5 (see Table 1). Simulation $2100 \mathrm{RCP} 4.5-\mathrm{NO}_{\mathrm{x}}$ has the same emissions as scenario RCP4.5 except that the $\mathrm{NO}_{\mathrm{x}}$ emissions are replaced by 2100 RCP 8.5 emissions. Similarly 

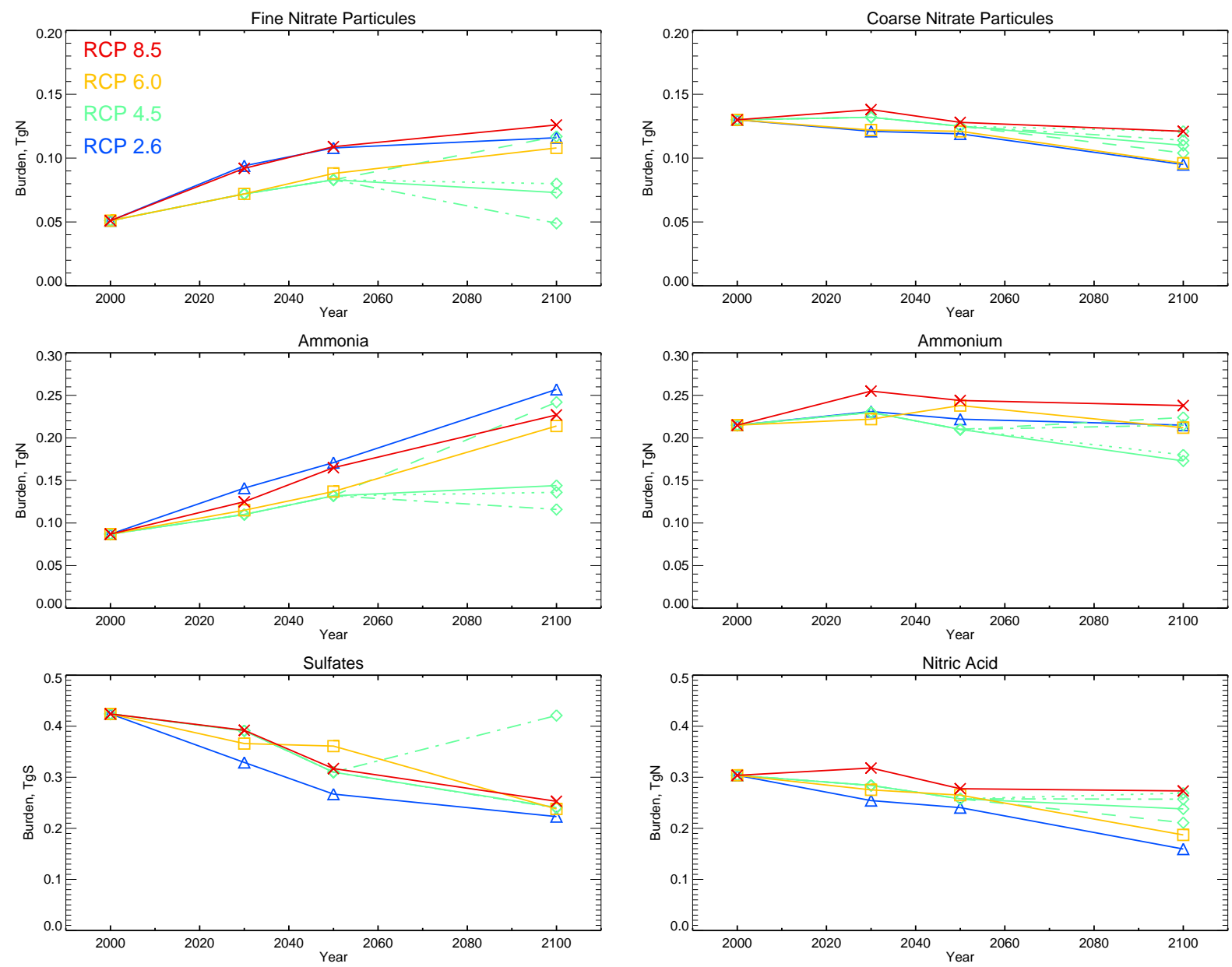

Figure 12. Evolution of the global burden of fine-mode nitrates, coarse-mode nitrates, ammonia, ammonium, nitric acid (Tg N), and sulfates (Tg S) in scenarios RCP8.5 (red), RCP6.0 (yellow), RCP4.5 (green), and RCP2.6 (blue) between the present-day and 2100. The dashed green line refers to the sensitivity scenario RCP4.5- $\mathrm{NH}_{3}$, the dotted green line to scenario $\mathrm{RCP} 4.5-\mathrm{NO}_{\mathrm{x}}$, and the dotted-dashed green line to scenario RCP4.5-SO $\mathrm{SO}_{2}$.

in simulation $2100 \mathrm{RCP} 4.5-\mathrm{NH}_{3}$, all emissions are similar to RCP4.5 except that the $\mathrm{NH}_{3}$ emissions are replaced by 2100 RCP8.5 emissions. Finally, in simulation $2100 \mathrm{RCP} 4.5-\mathrm{SO}_{2}$, all emissions are similar to RCP4.5 except that $\mathrm{SO}_{2}$ emissions are replaced by 2000 emissions. The latter are chosen to come not from the rather similar RCP8.5, and to isolate the impact of sulfates.

Figure 12 and Table 5 summarize the impact of these sensitivity simulations on the global burden of nitrates and related species in 2100. When $\mathrm{NH}_{3}$ emissions are increased to their RCP8.5 level (RCP4.5- $\mathrm{NH}_{3}$ ), the burden of $\mathrm{NH}_{3}$ increases to $0.24 \mathrm{Tg} \mathrm{N}$, a value even larger than in scenario RCP8.5. In this case, the fine nitrate burden increases to $0.12 \mathrm{Tg} \mathrm{N}$, showing that more than $80 \%$ of the difference in fine nitrates between RCP4.5 and RCP8.5 can be explained by the higher $\mathrm{NH}_{3}$ emissions in scenario RCP8.5. In this case, more ammonium nitrate is formed, and the $\mathrm{NH}_{4}^{+}$burden increases to $0.22 \mathrm{Tg} \mathrm{N}$, a value slightly below that in the
RCP8.5 scenario. This can be explained by the fact that less nitric acid is present in RCP4.5 compared to RCP8.5, and hence less ammonium nitrate is formed since $\mathrm{HNO}_{3}$ is the limiting species as seen in Fig. 11. Since ammonium sulfates form on preexisting $\mathrm{SO}_{4}^{=}$particles, changing the $\mathrm{NH}_{3}$ emissions has no effect on the sulfates themselves in this sensitivity simulation. The impact of somewhat higher $\mathrm{NO}_{\mathrm{x}}$ emissions (simulation $\mathrm{RCP} 4.5-\mathrm{NO}_{\mathrm{x}}$ ) increases the nitric acid burden to a value close to their RCP8.5 level. As a result, the fine nitrate burden increases by $0.01 \mathrm{Tg} \mathrm{N}$, explaining the remaining difference obtained between the RCP4.5 and RCP8.5 scenarios. These sensitivity simulations show that the strong difference calculated in fine nitrate particle levels in 2100 between scenario RCP4.5 and RCP8.5 can be explained mostly ( $80 \%$ ) by the higher $\mathrm{NH}_{3}$ emissions in the case of RCP8.5, and the remainder is explained by the higher $\mathrm{NO}_{\mathrm{x}}$ emissions. Finally, we illustrate the impact of higher $\mathrm{SO}_{2}$ emissions in the system (simulation RCP4.5-SO ${ }_{2}$ ). In this case, since 2000 
Table 5. Evolution of the tropospheric burdens of gaseous and particulate species for the various simulations performed in this study. Units are $\mathrm{Tg} \mathrm{N}$, except $\mathrm{SO}_{4}^{=}(\mathrm{TgS})$.

\begin{tabular}{lrrrrrr}
\hline Scenario & $\mathrm{HNO}_{3}$ & $\mathrm{NH}_{3}$ & $\mathrm{NH}_{4}^{+}$ & $\mathrm{SO}_{4}^{=}$ & Fine $\mathrm{NO}_{3}^{-}$ & Coarse $\mathrm{NO}_{3}^{-}$ \\
\hline 1850 & 0.14 & 0.05 & 0.08 & 0.19 & 0.01 & 0.08 \\
\hline 2000 & 0.30 & 0.09 & 0.21 & 0.42 & 0.05 & 0.13 \\
\hline 2030 RCP2.6 & 0.25 & 0.14 & 0.23 & 0.33 & 0.09 & 0.12 \\
2050 RCP2.6 & 0.24 & 0.17 & 0.22 & 0.27 & 0.11 & 0.12 \\
2100 RCP2.6 & 0.16 & 0.26 & 0.21 & 0.22 & 0.12 & 0.09 \\
\hline 2030 RCP4.5 & 0.28 & 0.11 & 0.23 & 0.39 & 0.07 & 0.13 \\
2050 RCP4.5 & 0.26 & 0.13 & 0.21 & 0.31 & 0.08 & 0.12 \\
2100 RCP4.5 & 0.24 & 0.14 & 0.17 & 0.24 & 0.07 & 0.11 \\
\hline 2030 RCP6.0 & 0.28 & 0.11 & 0.22 & 0.37 & 0.07 & 0.12 \\
2050 RCP6.0 & 0.27 & 0.14 & 0.24 & 0.36 & 0.09 & 0.12 \\
2100 RCP6.0 & 0.19 & 0.21 & 0.21 & 0.24 & 0.11 & 0.10 \\
\hline 2030 RCP8.5 & 0.32 & 0.12 & 0.25 & 0.39 & 0.09 & 0.14 \\
2050 RCP8.5 & 0.28 & 0.16 & 0.24 & 0.32 & 0.11 & 0.13 \\
2100 RCP8.5 & 0.27 & 0.23 & 0.24 & 0.25 & 0.13 & 0.12 \\
\hline Sensitivity simulations & & & & & & \\
\hline 2100 RCP4.5-NO & 0.27 & 0.14 & 0.18 & 0.24 & 0.08 & 0.12 \\
2100 RCP4.5-NH & 0.21 & 0.24 & 0.22 & 0.24 & 0.12 & 0.10 \\
2100 RCP4.5-SO 2 & 0.26 & 0.12 & 0.21 & 0.42 & 0.05 & 0.11 \\
\hline
\end{tabular}

emissions have been used, as expected the $\mathrm{SO}_{4}^{=}$burden increases to the present-day value. As a consequence, more $\mathrm{NH}_{3}$ is used to neutralize the sulfates and form ammonium sulfates, and the fine nitrate burden decreases by $0.02 \mathrm{Tg} \mathrm{N}$.

\subsection{Surface deposition}

We have also investigated the evolution of total nitrogen deposition $\left(\mathrm{NO}_{\mathrm{y}}+\mathrm{NH}_{\mathrm{x}}\right.$, wet and dry deposition) averaged over various regions of the world (see Supplement). In Europe and North America, the total $\mathrm{N}$ deposition slightly decreases or remains close to its present-day value in the case of scenario RCP8.5. In these regions, the $\mathrm{NO}_{\mathrm{y}}$ deposition significantly decreases in the future due to reduced $\mathrm{NO}_{\mathrm{x}}$ emissions (from $360 \mathrm{mg} \mathrm{N} \mathrm{m}^{-2} \mathrm{yr}^{-1}$ to $88-150 \mathrm{mg} \mathrm{N} \mathrm{m}^{-2} \mathrm{yr}^{-1}$ in Europe in 2100 and from $265 \mathrm{mg} \mathrm{N} \mathrm{m}^{-2} \mathrm{yr}^{-1}$ to 60 $108 \mathrm{mg} \mathrm{N} \mathrm{m}^{-2} \mathrm{yr}^{-1}$ in North America). However, this decrease is largely compensated by an increase in $\mathrm{NH}_{\mathrm{x}}$ deposition. In Europe for instance, this term increases from $426 \mathrm{mg} \mathrm{N} \mathrm{m}^{-2} \mathrm{yr}^{-1}$ to $672 \mathrm{mg} \mathrm{N} \mathrm{m}^{-2} \mathrm{yr}^{-1}$ in 2100 for $\mathrm{RCP} 8.5$. As a consequence, the fraction of $\mathrm{N}$ deposited as $\mathrm{NH}_{\mathrm{x}}$ increases from about $50 \%$ for the present-day to 70 $80 \%$ in 2100 in these two regions. In Asia and India, the $\mathrm{NO}_{y}$ deposition generally increases in 2030 or 2050 due to higher $\mathrm{NO}_{\mathrm{x}}$ emissions in these regions before decreasing at the end of the 21 st century. In addition, the $\mathrm{NH}_{\mathrm{x}}$ deposition generally increases during the course of the century to reach maximum values in 2100 . As a result, the total $\mathrm{N}$ deposition generally reaches a maximum in 20302050 and further increases or remains stable until 2100. In northern Asia (mostly China) for instance, the total deposition increases from $965 \mathrm{mg} \mathrm{N} \mathrm{m}^{-2} \mathrm{yr}^{-1}$ for the present to up to $1443 \mathrm{mg} \mathrm{N} \mathrm{m}^{-2} \mathrm{yr}^{-1}$ in 2050 before decreasing to $880-1251 \mathrm{mg} \mathrm{N} \mathrm{m}^{-2} \mathrm{yr}^{-1}$ in 2100 . In India, the deposition increases during the century from a present-day value of $780 \mathrm{mg} \mathrm{N} \mathrm{m}^{-2} \mathrm{yr}^{-1}$ to $1100-1700 \mathrm{mg} \mathrm{N} \mathrm{m}^{-2} \mathrm{yr}^{-1}$ in 2100 . As seen in other regions, this increase in total $\mathrm{N}$ deposition is also associated with a new balance between $\mathrm{NO}_{\mathrm{y}}$ and $\mathrm{NH}_{\mathrm{x}}$ deposition. The fraction of $\mathrm{N}$ deposited as $\mathrm{NH}_{\mathrm{x}}$ increases from about $60 \%$ to $80 \%$ in these regions. The same tendency is found over oceanic regions and globally. The total $\mathrm{N}$ deposited remains fairly stable or slightly decreases in these regions during the 21 st century, but the fraction of $\mathrm{N}$ deposited as $\mathrm{NH}_{\mathrm{x}}$ increases from $45 \%$ to $55-70 \%$ over the ocean and from $55 \%$ to $70-80 \%$ globally. This feature has possible strong consequences for terrestrial or oceanic ecosystems because deposition of nitric acid, which dissociates readily in water, causes a significant drop in $\mathrm{pH}$, but deposition of $\mathrm{NH}_{\mathrm{x}}$ increases the water alkalinity (Doney et al., 2007).

\subsection{Anthropogenic aerosol optical depths and radiative forcings}

Table 6 gives the anthropogenic aerosol optical depth at $550 \mathrm{~nm}$ for the various aerosol components and for the 
Table 6. Aerosol optical depth (AOD) at $550 \mathrm{~nm}(\times 1000)$ for 1850 and 2000 and anthropogenic AOD $(\times 1000)$ for the various simulations performed in this study. The anthropogenic AOD is calculated by subtracting the $1850 \mathrm{AOD}$ from the considered scenario.

\begin{tabular}{lrrrrr}
\hline Scenario & $\mathrm{NO}_{3}^{-}$ & $\mathrm{SO}_{4}^{=}$ & $\mathrm{OC}$ & $\mathrm{BC}$ & Total \\
\hline \multicolumn{7}{l}{ Aerosol optical depth } \\
\hline 1850 & 1.70 & 14.70 & 13.67 & 1.14 & 31.18 \\
2000 & 5.27 & 32.18 & 18.77 & 2.45 & 58.67 \\
\hline Anthropogenic aerosol optical depth & & \\
\hline 2000 & 3.57 & 17.51 & 5.09 & 1.31 & 27.49 \\
\hline 2030 RCP2.6 & 7.41 & 9.92 & 5.42 & 1.49 & 24.23 \\
2050 RCP2.6 & 8.19 & 5.15 & 3.55 & 0.87 & 17.76 \\
2100 RCP2.6 & 8.02 & 2.03 & 2.10 & 0.35 & 12.49 \\
\hline 2030 RCP4.5 & 5.55 & 14.59 & 2.93 & 1.51 & 24.58 \\
2050 RCP4.5 & 6.20 & 8.42 & 2.52 & 1.23 & 18.38 \\
2100 RCP4.5 & 5.26 & 3.36 & 0.31 & 0.43 & 9.36 \\
\hline 2030 RCP6.0 & 5.77 & 13.08 & 4.96 & 1.53 & 25.35 \\
2050 RCP6.0 & 7.00 & 12.40 & 5.34 & 1.46 & 26.20 \\
2100 RCP6.0 & 7.57 & 3.15 & 4.84 & 0.79 & 16.35 \\
\hline 2030 RCP8.5 & 7.39 & 14.57 & 4.48 & 1.46 & 27.89 \\
2050 RCP8.5 & 8.63 & 8.94 & 3.31 & 1.11 & 21.99 \\
2100 RCP8.5 & 9.57 & 4.20 & 1.75 & 0.66 & 16.17 \\
\hline
\end{tabular}

different performed simulations. As in Bellouin et al. (2011), we define the anthropogenic optical depth by subtracting the optical depth calculated in 1850 from the calculated value. The total anthropogenic optical depth decreases in all scenarios from a present-day value of 0.027 to a range of 0.009 for RCP4.5 to 0.016 for RCP6.0 and RCP8.5 in 2100 . The anthropogenic optical depth of all aerosols decreases from 2000 to 2100 in all scenarios except for nitrates, for which the optical depth increases in all RCP storylines. The nitrate optical depth increases from 0.004 in 2000 to a range of 0.005 for RCP4.5 to 0.009 for RCP8.5 in 2100. Figure 13 summarizes the contributions of the various aerosol components to this total anthropogenic optical depth. For the present-day, sulfates have the largest contribution of $64 \%$. Organic carbon and $\mathrm{BC}$ contribute, respectively, $19 \%$ and $5 \%$ to the anthropogenic optical depth. Nitrates have a contribution of $13 \%$. In the future, the contribution of sulfate decreases in all scenarios to a range of $16 \%$ in the case of RCP2.6 to $36 \%$ for RCP4.5 in 2100. The contribution of BC in 2100 ranges from $3 \%$ for RCP2.6 to $5 \%$ in RCP6.0, and the contribution of OC from $3 \%$ in RCP4.5 to $30 \%$ in RCP6.0. In all scenarios, we calculate an increasing contribution of nitrates to the anthropogenic aerosol optical depth, and in 2100 , nitrates become the dominant contributors to the anthropogenic optical depth. This contribution in 2100 ranges from $46 \%$ for RCP6.0 to $64 \%$ in RCP2.6.
Table 7 gives the all-sky direct radiative forcings since 1850 at the top of the atmosphere (TOA) of the various aerosol components calculated for the different scenarios and time horizon. The total forcing decreases from a presentvalue of $-0.23 \mathrm{~W} \mathrm{~m}^{-2}$ to $-0.11,-0.07,-0.11$, and -0.13 in scenarios RCP2.6, 4.5, 6.0, and 8.5, respectively. The geographical distribution of the total direct forcing in scenario RCP8.5 is shown in Fig. 14. In 2000, the forcing is strongly dominated by the negative sulfate forcing in the northern hemisphere with negative values over the continents reaching $-6 \mathrm{~W} \mathrm{~m}^{-2}$ in China. The positive forcing associated with $\mathrm{BC}$ dominates in several areas, in particular in the tropics, in biomass burning regions, and over regions with high surface albedo (see also Fig. 9 for the individual aerosol forcings in 2000). In 2100, the negative total forcing decreases but remains negative over most of the Northern Hemisphere. The maximum negative forcings are calculated over the central US, where the nitrate forcing is high, and over India and China. In these regions, the negative forcing reaches $-1.6 \mathrm{~W} \mathrm{~m}^{-2}$. The positive forcing also decreases, except over the southeastern United States, due to decreasing emissions of OC since 1850.

Figure 15 shows the evolution of the radiative forcings associated with the various aerosol components in the different RCP scenarios. As discussed above, the total aerosol forcing decreases from 2000 to 2100 in all scenarios. The negative forcing associated with sulfates decreases from $-0.31 \mathrm{~W} \mathrm{~m}^{-2}$ in 2000 to a range of $-0.03 \mathrm{~W} \mathrm{~m}^{-2}$ for RCP2.6 to $-0.08 \mathrm{~W} \mathrm{~m}^{2}$ for RCP8.5. Similarly, the forcing arising from OC decreases from $-0.06 \mathrm{~W} \mathrm{~m}^{-2}$ in 2000 to $-0.03 \mathrm{~W} \mathrm{~m}^{-2}$ in 2100 for RCP4.5 and to $-0.05 \mathrm{~W} \mathrm{~m}^{2}$ for RCP6.0. In addition, the positive forcing associated with BC decreases from $0.19 \mathrm{~W} \mathrm{~m}^{-2}$ in 2000 to $0.04-0.10 \mathrm{~W} \mathrm{~m}^{-2}$ in 2100. In contrast to the other aerosol components, the nitrate negative forcing increases in all scenarios from a presentday value of $-0.05 \mathrm{~W} \mathrm{~m}^{2}$ to a value ranging in 2100 from $-0.06 \mathrm{~W} \mathrm{~m}^{-2}$ for RCP4.5 to $-0.11 \mathrm{~W} \mathrm{~m}^{-2}$ for RCP8.5.

Finally, Fig. 16 summarizes the impact of nitrates on the future evolution of the anthropogenic AOD at 550nm and on the direct radiative forcing of aerosols at the top of the atmosphere. This figure can be compared to the results shown by Bellouin et al. (2011). As indicated before, the anthropogenic aerosol optical depth generally decreases in all scenarios. Nitrates have an increasing contribution to this AOD, and their contribution increases the AOD in 2100 from a factor of 1.8 for RCP6.0 to a factor of 2.8 for RCP2.6. These results are similar to Bellouin et al. (2011), who calculated a ratio for the AOD with and without nitrates of 2 in the case of RCP6.0 and 3.3 in the case of RCP2.6. The total aerosol forcing significantly decreases in all scenarios as a consequence of emission reductions for the main aerosols and aerosol precursors. In contrast, we have seen that the negative nitrate forcing increases in the future in all scenarios due to higher emissions of $\mathrm{NH}_{3}$ from agriculture. Including nitrates in the radiative forcing calculations significantly increases the total 

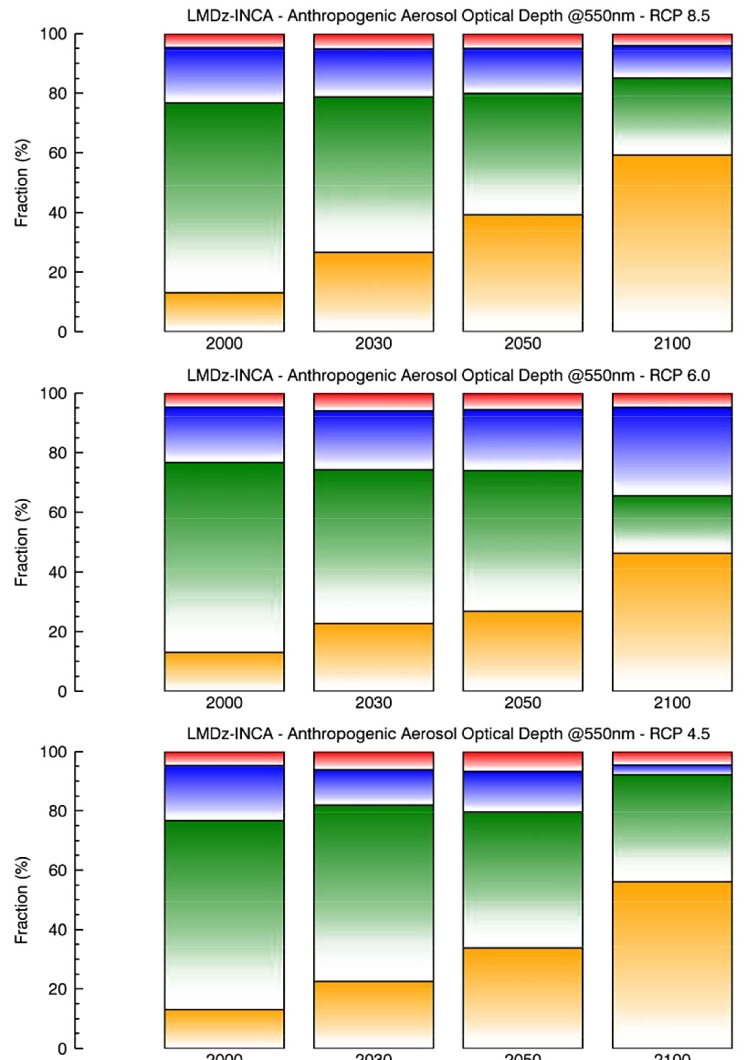

2000

pogenic Aerosol Optical Depth @550nm - RCP 4.5
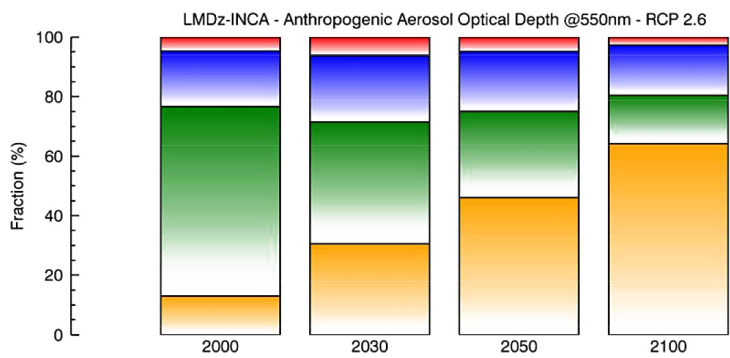

Figure 13. Evolution of the contribution (\%) of nitrates (yellow), sulfates (green), organic carbon (blue), and black carbon (red) to the total aerosol anthropogenic optical depth at $550 \mathrm{~nm}$ in the four RCP scenarios and from the present-day to 2100 .

direct forcing of aerosols by a factor of 1.3 in 2000 , by a factor of $1.7-2.6$ in 2030, by $1.9-4.8$ in 2050 , and by $6.4-8.6$ in 2100. These ratios are larger than Bellouin et al. (2011), who included the first indirect effect in the aerosol forcing. These results show that due to increasing $\mathrm{NH}_{3}$ emissions from agriculture in the future, nitrates have the potential to maintain the aerosol forcing at significantly higher values than those expected without including them in the climate simulations, and to become the main agent contributing to this forcing.
Table 7. All-sky direct radiative forcing at the top of the atmosphere (TOA) of the various aerosol components since the year 1850 and future evolution under the different scenarios considered in this study $\left(\mathrm{mW} \mathrm{m}^{-2}\right)$.

\begin{tabular}{lrrrrr}
\hline Scenario & $\mathrm{NO}_{3}^{-}$ & $\mathrm{SO}_{4}^{=}$ & $\mathrm{OC}$ & $\mathrm{BC}$ & Total \\
\hline 2000 & -56 & -315 & -56 & 194 & -234 \\
\hline 2030 RCP2.6 & -95 & -118 & -60 & 182 & -153 \\
2050 RCP2.6 & -102 & -94 & -39 & 107 & -130 \\
2100 RCP2.6 & -96 & -33 & -25 & 40 & -113 \\
\hline 2030 RCP4.5 & -76 & -270 & -29 & 187 & -189 \\
2050 RCP4.5 & -78 & -159 & -25 & 152 & -110 \\
2100 RCP4.5 & -60 & -60 & -3 & 53 & -70 \\
\hline 2030 RCP6.0 & -79 & -235 & -57 & 187 & -184 \\
2050 RCP6.0 & -94 & -225 & -59 & 180 & -198 \\
2100 RCP6.0 & -91 & -58 & -55 & 98 & -106 \\
\hline 2030 RCP8.5 & -101 & -273 & -49 & 181 & -241 \\
2050 RCP8.5 & -108 & -173 & -40 & 138 & -184 \\
2100 RCP8.5 & -115 & -79 & -18 & 82 & -130 \\
\hline
\end{tabular}

\section{Conclusions}

In this paper, the ammonia cycle and nitrate particle heterogeneous formation have been introduced into the LMDzINCA global model. The model treats ammonia and nitrates interactively with the full tropospheric chemistry and the other types of aerosols. An important feature of this new model is that both fine nitrate particle formation in the accumulation mode from nitric acid and ammonia reaction, and coarse nitrate particles forming on existing dust and seasalt particles are considered. The model developed in this work reproduces distributions of nitrates and related species in agreement with previous pioneering studies. The presentday surface concentrations of sulfates, nitrates, and ammonium have been evaluated by comparison against network measurements from the EBAS database. In Europe and North America, the model captures the sulfates measurements with a mean bias of about $20 \%$. As obtained with other models, ammonium and nitrates particles are more difficult to reproduce and higher biases are obtained, reaching, for nitrates, 60 and $100 \%$ over Europe and North America, respectively. A positive bias in simulated nitrate aerosol concentrations is suspected to be partly linked to negative sampling artifacts in measurements because evaporation of ammonium nitrate has been frequently reported to create occasionally losses of up to $50 \%$, in particular in warm weather. Further work is needed to better characterize the individual nitrate measurement error to see where modeled nitrate is consistent with measurements. The model total sulfate, ammonia, and nitrate depositions have also been compared to network measurements. This evaluation shows a reasonable agreement over Europe and North America for these three terms, with mean 

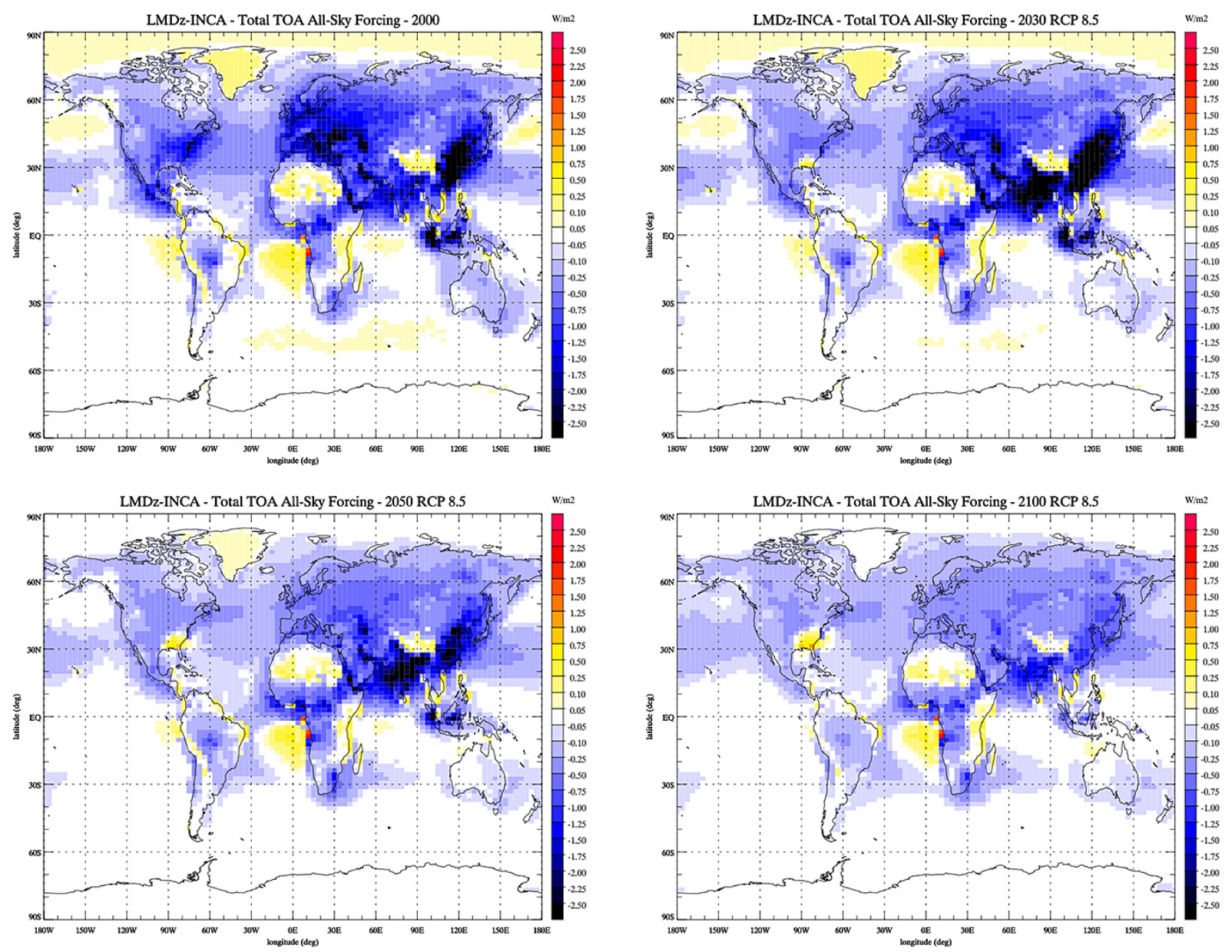

Figure 14. All-sky, top-of-the-atmosphere total direct aerosol radiative forcing $\left(\mathrm{W} \mathrm{m}^{-2}\right)$ calculated for the present-day and for 2030,2050 , and 2100 under scenario RCP8.5.

biases of about $20-30 \%$ or better. This is not the case in eastern Asia, where systematically underestimated depositions are calculated. This points to the need to further improve the emission inventories in this region and in China in particular. The calculated total aerosol optical depth distribution is generally well reproduced by the model with a mean bias against the AERONET observations of $-11 \%$.

The main objective of this work is to investigate the direct radiative forcing of climate of fine and coarse nitrate particles for both present-day and future conditions and investigate their relative contribution to the total aerosol forcing. Fine nitrate particles represent less than $30 \%$ of the total nitrate burden. Nitrates contribute $13 \%$ to the anthropogenic AOD since the pre-industrial (1850). The calculated present-day total nitrate direct radiative forcing since the pre-industrial at the top of the atmosphere is $-0.056 \mathrm{~W} \mathrm{~m}^{-2}$. Despite their small contribution to the total nitrate burden, fine particles largely dominate the nitrate forcing, representing close to $90 \%$ of this forcing. The present-day nitrate direct radiative forcing has the same magnitude as the forcing associated with organic carbon particles and represents $18 \%$ of the sulfate forcing. The nitrate forcing is subject to a significant spread in the previous model estimates. The forcing calculated with this model is within the range of -0.03 to $-0.17 \mathrm{~W} \mathrm{~m}^{-2}$ reported by Myhre et al. (2013) but in the lower range of this multi-model estimate. We note that both fine and coarse nitrate formation have been included in our calculations. This feature is important since coarse nitrate formation depletes gas-phase $\mathrm{HNO}_{3}$, reducing the formation of fine particles of ammonium nitrate and hence decreasing the total forcing of nitrate particles.

The model has been used to investigate the future changes in nitrate concentration and direct radiative forcing of climate based on the four RCP scenarios and for the 2030, 2050, and 2100 time horizons. Due to a decrease in fossil fuel emissions in the future, the concentration of most of the species involved in the nitrate-ammonium-sulfate system drop by 2100 under the different scenarios. This is not the case for ammonia, which originates from agricultural practices and for which emissions significantly increase in the future. As a consequence, $\mathrm{NH}_{3}$ future concentrations significantly increase in India, in eastern Asia, and in North America in 

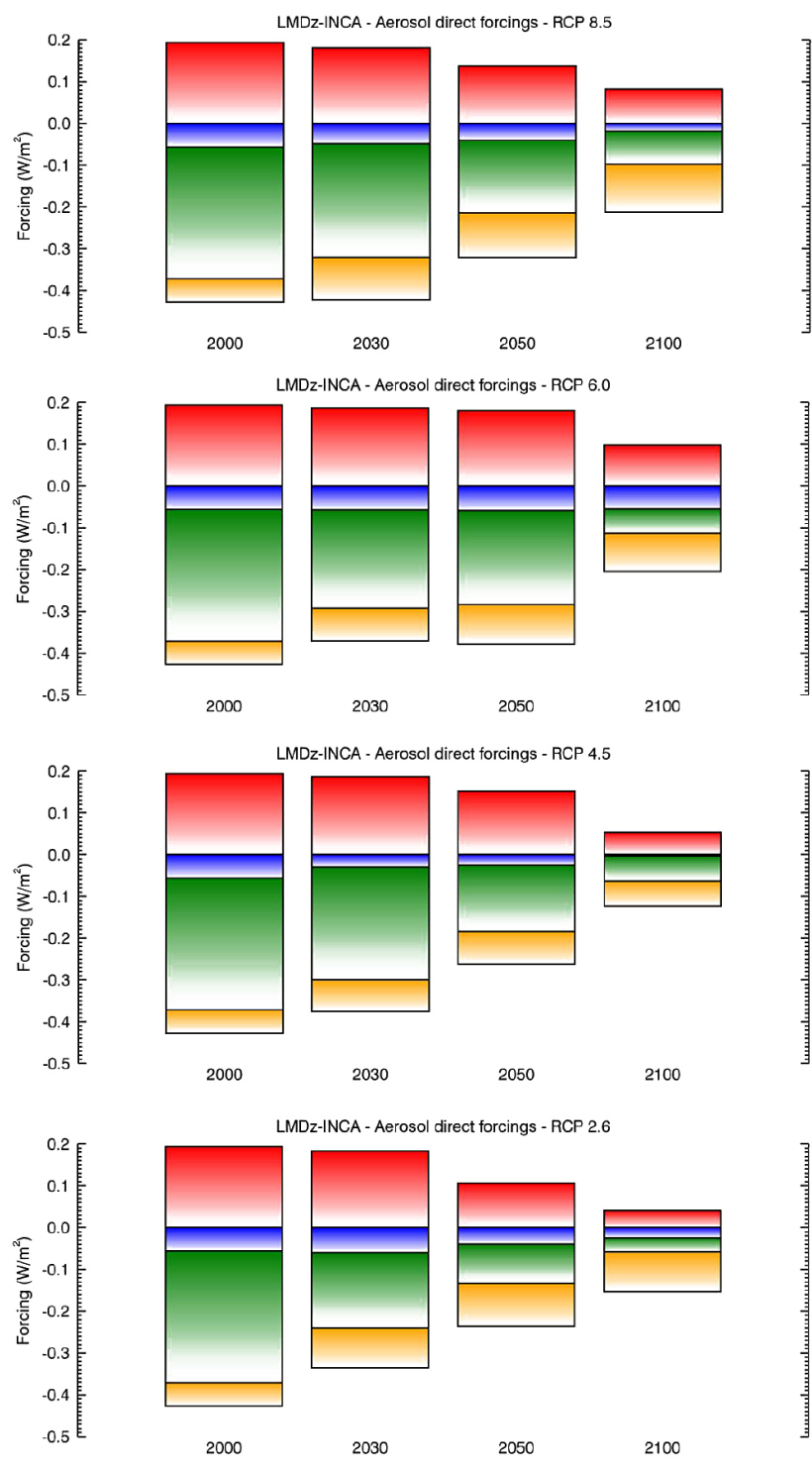

Figure 15. All-sky, top-of-the-atmosphere direct radiative forcing $\left(\mathrm{W} \mathrm{m}^{-2}\right.$ ) of nitrates (yellow), sulfates (green), organic carbon (blue), and black carbon (red) calculated in the four RCP scenarios and from the present-day to 2100 .

the four scenarios, but also in Europe in the most extreme scenario RCP8.5. Despite this increase in $\mathrm{NH}_{3}$ surface levels, the surface concentration of nitrates decreases in Europe and North America due a significant reduction in $\mathrm{NO}_{\mathrm{x}}$ and hence $\mathrm{HNO}_{3}$ concentration at the surface. In other regions (India, Asia), the surface nitrate concentration generally increases until 2030-2050 due to increasing $\mathrm{NO}_{\mathrm{x}}$ and $\mathrm{NH}_{3}$ and then decrease until 2100. Due to the significant reduction in $\mathrm{SO}_{4}^{=}$levels in the future and concomitant increase in $\mathrm{NH}_{3}$, large regions of the atmosphere, not only at the surface but also in the free troposphere, shift from an ammonium sulfate to an ammonium nitrate formation regime. As a consequence, despite the decrease of nitrates at the surface level in several regions, the global burden of accumulation-mode nitrates in the atmosphere increases by a factor of 1.4-2.6 in 2100, depending on the scenario. This range is associated with $80 \%$ of the range of future $\mathrm{NH}_{3}$ emissions among the various scenarios with $\mathrm{NO}_{\mathrm{x}}$ emissions contributing to the remaining variability between the different scenarios. The total nitrogen $\left(\mathrm{NH}_{\mathrm{x}}+\mathrm{NO}_{\mathrm{y}}\right)$ deposition generally increases or remains fairly stable in the future in the different scenarios. However, this feature is mostly associated with a decrease in $\mathrm{NO}_{\mathrm{y}}$ deposition and an increase in $\mathrm{NH}_{\mathrm{x}}$ deposition. As a consequence, the fraction of nitrogen deposited as $\mathrm{NH}_{\mathrm{x}}$ increases from about $50 \%$ for the present-day to $70-80 \%$ by 2100. This feature has strong possible consequences for the environment because as nitric acid causes a significant drop in $\mathrm{pH}, \mathrm{NH}_{\mathrm{x}}$, in contrast, increases the water alkalinity.

The total anthropogenic AOD decreases in all scenarios from a present-day value of 0.027 to a range of 0.009 for RCP4.5 to 0.016 for RCP6.0 and RCP8.5 in 2100. Since all aerosols concentrations decrease in the future except for nitrates, they become the dominant contributors to anthropogenic AOD. Their contribution increases from $13 \%$ for the present-day to $46-64 \%$ in 2100 depending on the considered scenario. The total aerosol direct forcing decreases from its present-day value of $-0.23 \mathrm{~W} \mathrm{~m}^{-2}$ to -0.07 to $-0.13 \mathrm{~W} \mathrm{~m}^{-2}$ in 2100 based on the considered scenario. As expected from the changes in the AOD, the direct forcing decreases for all aerosols in the future except for nitrates, for which the direct negative forcing increases from $-0.056 \mathrm{~W} \mathrm{~m}^{-2}$ in 2000 to a range of -0.060 to $-0.115 \mathrm{~W} \mathrm{~m}^{-2}$ in 2100 . Including nitrates in the radiative forcing calculations significantly increases the total direct forcing of aerosols by a factor of 1.3 in 2000, by a factor of $1.7-2.6$ in 2030 , by $1.9-4.8$ in 2050 , and by $6.4-8.6$ in 2100 . These results indicate that, due to increasing $\mathrm{NH}_{3}$ agricultural emissions in the future according to the RCP emission scenarios, nitrates become the dominant contributor to the anthropogenic aerosol optical depth during the second half of the 21 st century and significantly increase the calculated aerosol direct forcing.

Agricultural emissions of ammonia are found to play a key role in the future mitigation of climate change. It is found in this study that ammonium nitrate particles become the dominant contributor to the future direct forcing of aerosols. In addition, in terms of regional air quality, we have shown that nitrate levels at the surface are also significantly affected by future emissions of nitrate precursors with consequences on particulate matter levels and hence health impacts in North America, Europe, and Asia. The future ammonia emissions also affect the total nitrogen deposited at the surface, with possible consequences on land and ocean ecosystems. We note however that significant uncertainties remain in our simulations of future nitrate levels. The ammoniumnitrate-sulfate chemistry module used in this study has been designed for long-term coupled climate-chemistry simulations and remains relatively simple compared to the work of 

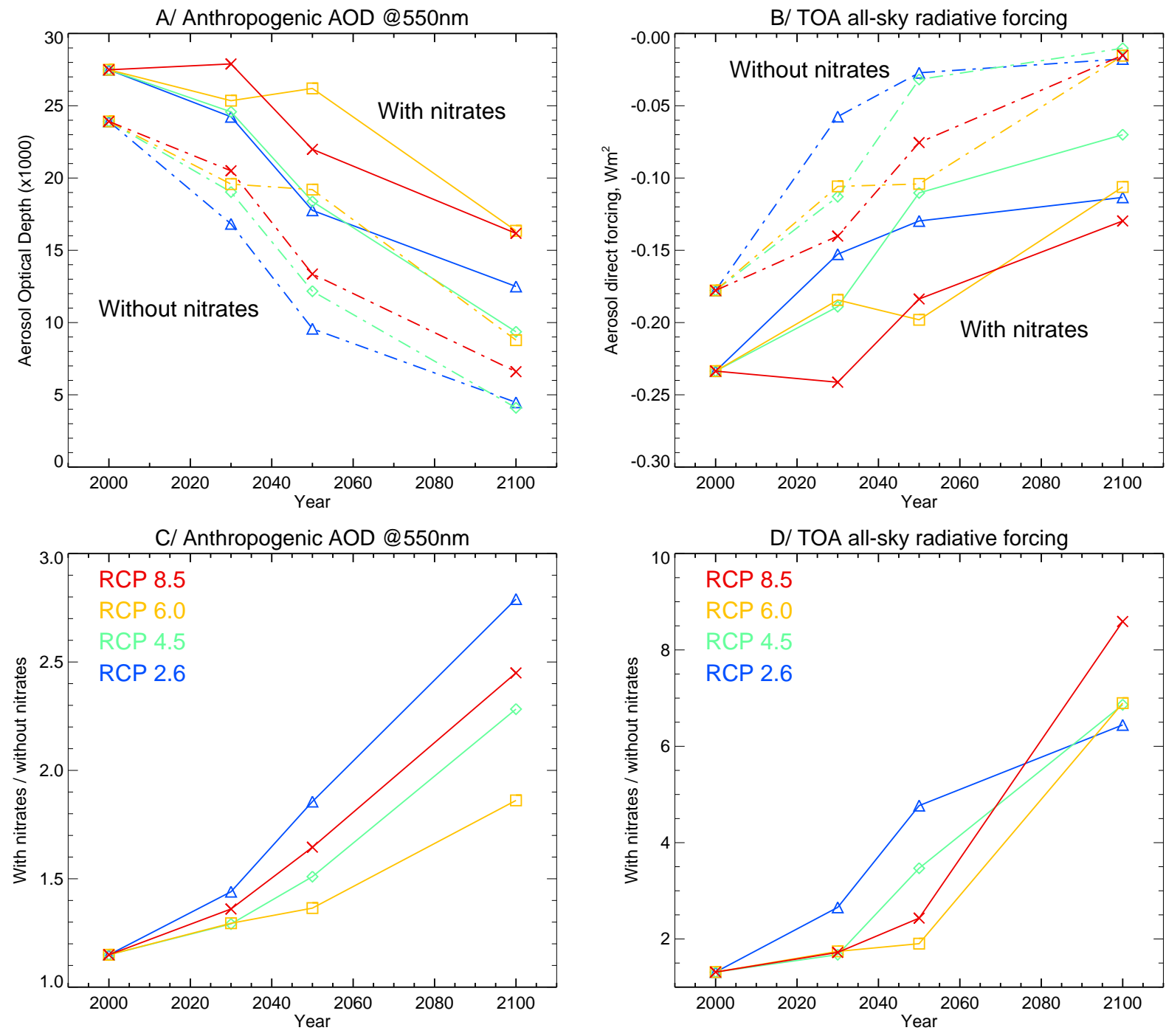

Figure 16. Evolution of (a) the aerosol anthropogenic optical depth at $550 \mathrm{~nm}(\times 1000)$ and (b) all-sky, top-of-the-atmosphere direct radiative forcing $\left(\mathrm{W} \mathrm{m}^{-2}\right)$ in the four RCP scenarios and from the present-day to 2100; RCP8.5 (red), RCP6.0 (yellow), RCP4.5 (green) and RCP2.6 (blue). Solids lines show nitrates included; dashed lines, nitrates excluded. Corresponding fractional contribution of nitrates to the (c) anthropogenic aerosol optical depth and (d) direct radiative forcing.

Nenes et al. (1998) for instance. This module could be improved in a future version of the model. We note however, the agreement with previous studies in terms of simulated distributions and in terms of comparison with measurements. Compared to these previous calculations, no particular biases were obtained. Another important limitation arises from the fact that in this study we analyze the role of future emissions acting separately on atmospheric composition. The impact of future climate change on nitrate formation or on dynamical regimes, future levels of oxidants, or on future biogenic emissions has not been considered. This will be investigated in forthcoming studies along with the impact of nitrate particles on the aerosol indirect effect. It should also be noted that this study is based on the RCP scenarios for the future evolution of surface emissions of pollutants. All RCP scenarios assume aggressive air pollution abatement measures and this assumption is a major caveat in the projections of future nitrate precursor emissions. In addition, the small range of possible air pollutant emission trajectories across the RCPs may not necessarily be representative of the true regional air quality legislation and hence emission pathways. This type of study needs to be investigated with more realistic emission scenarios for air pollutants when they become available.

As stressed in this work and previous studies before, nitrate is an increasingly important aerosol component which impacts climate, air quality, and ecosystems through nitrogen deposition. Nevertheless, despite this importance for future climate and air quality projections, and unlike other 
aerosol components, the simulation of nitrate particles from global models and their impact on climate has not yet been extensively evaluated. Such an evaluation in the framework of the AeroCom community effort (Schulz et al., 2006; Myhre et al., 2013) will be of great interest for better understanding the sources of uncertainty of this aerosol component and is currently underway (https://wiki.met.no/ aerocom/phase 3 -experiments). The results of this exercise will presented in future AeroCom publications.

\section{The Supplement related to this article is available online at doi:10.5194/acp-14-11031-2014-supplement.}

Acknowledgements. This study was co-funded by the European Commission under the EU Seventh Research Framework Programme (ECLAIRE and COMBINE projects), by ADEME under the ACHIA project, and by DGAC under the IMPACT project. D. A. Hauglustaine is grateful to J.-F. Lamarque for his assistance with the revised ammonia anthropogenic emissions. We thank A. Cozic for her continuous support with the LMDz-INCA model development and M. Mendez for his help with the use of ISORROPIA model. This work was performed using DSM-CCRT resources under the GENCI (Grand Equipement National de Calcul Intensif) computer time allocation. We are grateful to the numerous data providers of surface concentrations and deposition in the various networks (EMEP, NADP, IMPROVE, EANET). Also essential were the provision of the EBAS database extracts for model evaluation from NILU by Paul Eckhardt and help from Jan Griesfeller in preparing these data for the AeroCom tools, which is supported by the EU ACTRIS project and EMEP.

Edited by: M. Kanakidou

\section{References}

Ackermann, I. J., Hass, H., Memmesheimer, M., Ziegenbein, C., and Ebel, A.: The parameterization of the sulfate-nitrateammonia aerosol system in the long-range transport model EURAD, Meteorol. Atmos. Phys., 57, 101-114, 1995.

Adams, P. J., Seinfeld, J. H., and Koch, D. M.: Global concentrations of tropospheric sulfate, nitrate, and ammonium aerosol simulated in a general circulation model, J. Geophys. Res., 104, 13791-13823, 1999.

Adams, P. J., Seinfeld, J. H., Koch, D., Mickley, L., and Jacob, D.: General circulation model assessment of direct radiative forcing by the sulfate-nitrate-ammonium-water inorganic aerosol system, J. Geophys. Res., 106, 1097-1112, doi:10.1029/2000JD900512, 2001.

Balkanski, Y.: L'Influence des Aérosols sur le Climat, Thèse d'Habilitation à Diriger des Recherches, Université de Versailles Saint-Quentin, Saint-Quentin-en-Yvelines, 2011.

Bauer, S. E., Balkanski, Y., Schulz, M., Hauglustaine, D. A., and Dentener, F.: Global modeling of heterogeneous chemistry on mineral aerosol surfaces: influence on tropospheric ozone chemistry and comparison to observations, J. Geophys. Res., 109, D02304, doi:10.1029/2003JD003868, 2004.
Bauer, S. E., Koch, D., Unger, N., Metzger, S. M., Shindell, D. T., and Streets, D. G.: Nitrate aerosols today and in 2030: a global simulation including aerosols and tropospheric ozone, Atmos. Chem. Phys., 7, 5043-5059, doi:10.5194/acp-7-5043-2007, 2007.

Bellouin, N., Rae, J., Jones, A., Johnson, C., Haywood, J., and Boucher, O.: Aerosol forcing in the climate model intercomparison project (CMIP5) simulations by the HadGEM2-ES and the role of ammonium nitrate, J. Geophys. Res., 16, D20206, doi:10.1029/2001JD016074, 2011.

Bousquet, P., Hauglustaine, D. A., Peylin, P., Carouge, C., and Ciais, P.: Two decades of $\mathrm{OH}$ variability as inferred by an inversion of atmospheric transport and chemistry of methyl chloroform, Atmos. Chem. Phys., 5, 2635-2656, doi:10.5194/acp-52635-2005, 2005.

Bousquet, P., Yver, C., Pison, I., Li, Y. S., Fortems, A., Hauglustaine, D., Szopa, S., Rayner, P. J., Novelli, P., Langenfelds, R., Steele, P., Ramonet, M., Schmidt, M., Foster, P., Morfopulos, C., and Ciais, P.: A 3D synthesis inversion of the molecular hydrogen cycle: sources and sinks budget implications for the soil uptake, J. Geophys. Res., 116, D01302, doi:10.1029/2010JD014599, 2010.

Bouwman, A. F., Lee, D. S., Asman, W. A. H., Dentener, F. J., Van Der Hoek, K. W., and Olivier, J. G. J.: A global high-resolution emission inventory for ammonia, Global Biogeochem. Cy., 11, 561-587, 1997.

Brunner, D., Staehelin, J., Rogers, H. L., Köhler, M. O., Pyle, J. A., Hauglustaine, D. A., Jourdain, L., Berntsen, T. K., Gauss, M., Isaksen, I. S. A., Meijer, E., van Velthoven, P., Pitari, G., Mancini, E., Grewe, V., and Sausen, R.: An evaluation of the performance of chemistry transport models by comparison with research aircraft observations. Part 1: concepts and overall model performance, Atmos. Chem. Phys., 3, 1606-1631, 2003, http://www.atmos-chem-phys.net/3/1606/2003/.

Chin, M., Ginoux, P., Kinne, S., Holben, B. N., Duncan, B. N., Martin, R. V., Logan, J. A., Higurashi, A., and Nakajima, T.: Tropospheric Aerosol Optical Thickness from the GOCART Model and Comparisons with Satellite and Sun Photometer Measurements, J. Atmos. Sci., 59, 461-483, 2002.

Chung, S. H. and Seinfeld, J. H.: Global distribution and climate forcing of carbonaceous aerosols, J. Geophys. Res., 107, 4407, doi:10.1029/2001JD00397, 2002.

Claquin, T., Schulz, M., and Balkanski, Y. J.: Modeling the mineralogy of atmospheric dust source, J. Geophys. Res., 104, 22243 22256, 1999.

Clarisse, L., Clerbaux, C., Dentener, F., Hurtmans, D., and Coheur, P.-F.: Global ammonia distribution derived from infrared satellite observations, Nat. Geosci., 2, 479-483, 2009.

Cooke, W. F. and J. J. N. Wilson, A global black carbon aerosol model, J. Geophys. Res., 101, 19,395-19,409, 1996.

Dall'Osto, M., M., Harrison, R. M., Coe, H., Williams, P. I., and Allan, J. D.: Real time chemical characterization of local and regional nitrate aerosols, Atmos. Chem. Phys., 9, 3709-3720, doi:10.5194/acp-9-3709-2009, 2009.

Dentener, F. J. and Crutzen, P. J.: Reaction of $\mathrm{N}_{2} \mathrm{O}_{5}$ on tropospheric aerosols: impact on the global distributions of $\mathrm{NO}_{\mathrm{x}}, \mathrm{O}_{3}$, and $\mathrm{OH}$, J. Geophys. Res., 98, 7149-7163, 1993.

Dentener, F., Kinne, S., Bond, T., Boucher, O., Cofala, J., Generoso, S., Ginoux, P., Gong, S., Hoelzemann, J. J., Ito, A., Marelli, L., 
Penner, J. E., Putaud, J.-P., Textor, C., Schulz, M., van der Werf, G. R., and Wilson, J.: Emissions of primary aerosol and precursor gases in the years 2000 and 1750 prescribed data-sets for AeroCom, Atmos. Chem. Phys., 6, 4321-4344, doi:10.5194/acp-64321-2006, 2006a.

Dentener, F., Stevenson, D., Drevet, J., Lamarque, J.-F., Bey, I., Eickhout, B., Fiore, A., Hauglustaine, D., Horrowitz, L., Krol, M., Kuhlsherestha, U., Lawrence, M.,Galy-Lacaux, C., Rast, S., Shindell, D., Stevenson, D., Van Noije, T., Atherthon, C., Bell, N., Bergman, D., Butler, T., Cofala, J., Collins, W., Doherty, R., Ellingsen, K., Galloway, J., Gauss, M., Montanaro, V., Muller, J.-F., Pitari, G., Rodriquez, J., Sanderson, M., Strahan, S., Schultz, M., Sudo, K., Szopa, S., and Wild, O., Nitrogen and sulfur deposition on regional and global scales: a multimodel evaluation, Global Biogeochem. Cy., 20, GB4003, doi:10.1029/2005GB002672, 2006b.

Doney, S. C., Mahowald, N., Lima, I., Feely, R. A., Mackenzie, F. T., Lamarque, J.-F., and Rasch, P. J.: Impact of anthropogenic atmospheric nitrogen and sulfur deposition on ocean acidification and the inorganic carbon system, P. Natl. Acad. Sci., 104, 14580-14585, doi:10.1073/pnas.0702218104, 2007.

Dufour, G., Szopa, S., Hauglustaine, D. A., Boone, C. D., Rinsland, C. P., and Bernath, P. F.: The influence of biogenic emissions on upper-tropospheric methanol as revealed from space, Atmos. Chem. Phys., 7, 6119-6129, doi:10.5194/acp-7-61192007, 2007.

Emanuel, K. A.: A scheme for representing cumulus convection in large-scale models, J Atmos. Sci., 48, 2313-2335, 1991.

Evans, M. J. and Jacob, D. J.: Impact of new laboratory studies of N2O5 hydrolysis on global model budgets of tropospheric nitrogen oxides, ozone, and $\mathrm{OH}$, Geophys. Res. Lett., 32, L09813, doi:10.1029/2005GL022469, 2005.

Fairlie, T. D., Jacob, D. J., Dibb, J. E., Alexander, B., Avery, M. A., van Donkelaar, A., and Zhang, L.: Impact of mineral dust on nitrate, sulfate, and ozone in transpacific Asian pollution plumes, Atmos. Chem. Phys., 10, 3999-4012, doi:10.5194/acp-10-39992010, 2010.

Feng, Y., and Penner, J. E.: Global modeling of nitrate and ammonium: interaction of aerosols and tropospheric chemistry, J. Geophys. Res., 112, D01304, doi:10.1029/2005JD006404, 2007.

Fiore, A. M., Dentener, F. J., Wild, O., Cuvelier, C., Schultz, M. G., Hess, P., Textor, C., Schulz, M., Doherty, R. M., Horowitz, L. W., MacKenzie, I. A., Sanderson, M. G., Shindell, D. T., Stevenson, D. S., Szopa, S., Van Dingenen, R., Zeng, G., Atherton, C., Bergmann, D., Bey, I., Carmichael, G., Collins, W. J., Duncan, B. N., Faluvegi, G., Folberth, G., Gauss, M., Gong, S., Hauglustaine, D., Holloway, T., Isaksen, I. S. A., Jacob, D. J., Jonson, J. E., Kaminski, J. W., Keating, T. J., Lupu, A., Marmer, E., Montanaro, V., Park, R. J., Pitari, G., Pringle, K., J., Pyle, J. A., Schroeder, S., Vivanco, M. G., Wind, P., Wojcik, G., Wu, S., and Zuber, A.: Multi-model Estimates of Intercontinental SourceReceptor Relationships for Ozone Pollution, J. Geophys. Res., 114, D04301, doi:10.1029/2008JD010816, 2009.

Folberth, G. A., Hauglustaine, D. A., Lathière, J., and Brocheton, F.: Interactive chemistry in the Laboratoire de Météorologie Dynamique general circulation model: model description and impact analysis of biogenic hydrocarbons on tropospheric chemistry, Atmos. Chem. Phys., 6, 2273-2319, doi:10.5194/acp-62273-2006, 2006.
Forster, P., Ramaswamy, V., Artaxo, P., Berntsen, T., Betts, R., Fahey, D. W., Haywood, J., Lean, J., Lowe, D. C., Myhre, G., Nganga, J., Prinn, R., Raga, G., Schulz, M., and Van Dorland, R.: Changes in Atmospheric Constituents and in Radiative Forcing, in: Climate Change 2007: The Physical Science Basis. Contribution of Working Group I to the Fourth Assessment Report of the Intergovernmental Panel on Climate Change, edited by: Solomon, S., Qin, D., Manning, M., Chen, Z., Marquis, M., Averyt, K. B., Tignor, M., and Miller, H. L., Cambridge University Press, Cambridge, United Kingdom and New York, NY, USA, 2007.

Fouquart, Y. and Bonel, B.: Computations of solar heating of the earth's atmosphere: a new parameterization, Beitr. Phys. Atmos., 53, 35-62, 1980.

Gosse, S. F., Wang, M., Labrie, D., and Chylek, P.: Imaginary part of the refractive index of sulfates and nitrates in the $0.7-2.6 \mu \mathrm{m}$ spectral region, Appl. Opt., 36, 16, 3622-3634, 1997.

Gruber, N. and Galloway, J. N.: Earth-system perspective of the global nitrogen cycle, Nature, 451, 293-296, 2008.

Hauglustaine, D. A., Hourdin, F., Walters, S., Jourdain, L., Filiberti, M.-A., Larmarque, J.-F., and Holland, E. A.: Interactive chemistry in the Laboratoire de Météorologie Dynamique general circulation model: description and background tropospheric chemistry evaluation, J. Geophys. Res., 109, D04314, doi:10.1029/2003JD003957, 2004.

Heald, C. L., Collett Jr., J. L., Lee, T., Benedict, K. B., Schwandner, F. M., Li, Y., Clarisse, L., Hurtmans, D. R., Van Damme, M., Clerbaux, C., Coheur, P.-F., Philip, S., Martin, R. V., and Pye, H. O. T.: Atmospheric ammonia and particulate inorganic nitrogen over the United States, Atmos. Chem. Phys., 12, 10295-10312, doi:10.5194/acp-12-10295-2012, 2012.

Hertel, O., Reis, S., Skjoth, C. A., Bleeker, A., Harrison, R., Cape, J. N., Fowler, D., Skiba, U., Simpson, D., Jickells, T., Baker, A., Kulmala, M., Gyldenkaerne, S., Sorensen, L. L., and Erisman, J. W.: Nitrogen processes in the atmosphere, in: The European Nitrogen Assessment, edited by: Sutton, M. A., Howard, C. M., Erisman, J. W., Billen, G., Bleeker, A., Grennfelt, P., van Grinsven, H., and Grizzetti, B., Cambridge University Press, Cambridge, 177-207, 2011.

Holben, B. N., Tanre, D., Smirnov, A., Eck, T. F., Slutsker, I., Abuhassan, N., Newcomb, W. W., Schafer, J., Chatenet, B., Lavenue, F., Kaufman, Y. J., Vande Castle, J., Setzer, A., Markham, B., Clark, D., Frouin, R., Halthore, R., Karnieli, A., O’Neill, N. T., Pietras, C., Pinker, R. T., Voss, K., and Zibordi, G.: An emerging ground-based aerosol climatology: aerosol optical depth from AERONET, J. Geophys. Res., 106, 12067-12097, 2001.

Hourdin, F. and Armengaud, A.: The use of finite-volume methods for atmospheric advection of trace species -1 . test of various formulations in a general circulation model, Mon. Weather Rev., 127, 822-837, 1999.

Hourdin, F. and Issartel, J. P.: Sub-surface nuclear tests monitoring through the CTBT xenon network, Geophys. Res. Lett., 27, 2245-2248, 2000.

Hourdin, F., Musat, I., Bony, S., Braconnot, P., Codron, F., Dufresne, J.-L., Fairhead, L., Filiberti, M.-A., Friedlingstein, P., Grandpeix, J.-Y., Krinner, G., Levan, P., Li, Z.-X., and Lott, F.: The LMDZ4 general circulation model: climate performance and 
sensitivity to parametrized physics with emphasis on tropical convection, Clim. Dynam., 27, 787-813, 2006.

Hov, O., Eliassen, A., and Simpson, D.: Calculation of the distribution of $\mathrm{NO}_{\mathrm{x}}$ compounds in Europe, in: Tropospheric Ozone, Regional and Global Scale Interactions, edited by: Isaksen, I. S. A., 239-261, Reidel, Dordrecht, 1988.

Irshad, R., Grainger, R. G., Peters, D. M., McPheat, R. A., Smith, K. M., and Thomas, G.: Laboratory measurements of the optical properties of sea salt aerosol, Atmos. Chem. Phys., 9, 221-230, doi:10.5194/acp-9-221-2009, 2009.

Jacobson, M. Z.: Studying the effects of calcium and magnesium on size-distributed nitrate and ammonium with EQUISOLV II, Atmos. Environ., 33, 3635-3649, 1999.

Jacobson, M. Z.: Global direct radiative forcing due to multicomponent anthropogenic and natural aerosols, J. Geophys Res., 106, 1551-1568, 2001.

Jarzembski, M. A., Norman, M. L., Fuller, K. A., Srivastava, V., and Cutten, D. R.: Complex refractive index of ammonium nitrate in the 2-20 $\mu \mathrm{m}$ spectral range, Appl. Optics, 42, 922-930, 2003.

Kinne, S., Schulz, M., Textor, C., Guibert, S., Balkanski, Y., Bauer, S. E., Berntsen, T., Berglen, T. F., Boucher, O., Chin, M., Collins, W., Dentener, F., Diehl, T., Easter, R., Feichter, J., Fillmore, D., Ghan, S., Ginoux, P., Gong, S., Grini, A., Hendricks, J., Herzog, M., Horowitz, L., Isaksen, I., Iversen, T., Kirkevåg, A., Kloster, S., Koch, D., Kristjansson, J. E., Krol, M., Lauer, A., Lamarque, J. F., Lesins, G., Liu, X., Lohmann, U., Montanaro, V., Myhre, G., Penner, J., Pitari, G., Reddy, S., Seland, O., Stier, P., Takemura, T., and Tie, X.: An AeroCom initial assessment - optical properties in aerosol component modules of global models, Atmos. Chem. Phys., 6, 1815-1834, doi:10.5194/acp-6-1815-2006, 2006.

Koffi, B., Schulz, M., Breon, F.-M., Griesfeller, J., Winker, D., Balkanski, Y., Bauer, S., Berntsen, T., Chin, M., Collins, W. D., Dentener, F., Diehl, T., Easter, R., Ghan, S., Ginoux, P., Gong, S., Horowitz, L. W., Iversen, T., Kirkevag, A., Koch, D., Krol, M., Myhre, G., Stier, P., and Takemura, T.: Application of the CALIOP layer product to evaluate the vertical distribution of aerosols estimated by global models: AeroCom phase I results, J. Geophys. Res., 117, D10201, doi:10.1029/2011JD016858, 2012.

Krinner, G., Viovy, N., de Noblet-Ducoudre, N., Ogee, J., Polcher, J., Friedlingstein, P., Ciais, P., Sitch, S., and Prentice, I. C.: A dynamic global vegetation model for studies of the coupled atmosphere-biosphere system, Global Biogeochem. Сy., 19, GB1015, doi:10.1029/2003GB002199, 2005.

Lamarque, J.-F., Bond, T. C., Eyring, V., Granier, C., Heil, A., Klimont, Z., Lee, D., Liousse, C., Mieville, A., Owen, B., Schultz, M. G., Shindell, D., Smith, S. J., Stehfest, E., Van Aardenne, J., Cooper, O. R., Kainuma, M., Mahowald, N., McConnell, J. R., Naik, V., Riahi, K., and van Vuuren, D. P.: Historical (1850-2000) gridded anthropogenic and biomass burning emissions of reactive gases and aerosols: methodology and application, Atmos. Chem. Phys., 10, 7017-7039, doi:10.5194/acp10-7017-2010, 2010.

Lamarque, J.-F., Kyle, G. P., Meinshausen, M., Riahi, K., Smith, S. J., van Vuuren, D. P., Conley, A. J., and Vitt, F.: Global and regional evolution of short-lived radiatively-active gases and aerosols in the Representative Concentration Pathways, Climatic Change, 109, 191-212, doi:10.1007/s10584-011-0155-0, 2011.
Lamarque, J.-F., Dentener, F., McConnell, J., Ro, C.-U., Shaw, M., Vet, R., Bergmann, D., Cameron-Smith, P., Dalsoren, S., Doherty, R., Faluvegi, G., Ghan, S. J., Josse, B., Lee, Y. H., MacKenzie, I. A., Plummer, D., Shindell, D. T., Skeie, R. B., Stevenson, D. S., Strode, S., Zeng, G., Curran, M., DahlJensen, D., Das, S., Fritzsche, D., and Nolan, M.: Multi-model mean nitrogen and sulfur deposition from the Atmospheric Chemistry and Climate Model Intercomparison Project (ACCMIP): evaluation of historical and projected future changes, Atmos. Chem. Phys., 13, 7997-8018, doi:10.5194/acp-13-79972013, 2013.

Lathière, J., Hauglustaine, D. A., Friend, A. D., De NobletDucoudré, N., Viovy, N., and Folberth, G. A.: Impact of climate variability and land use changes on global biogenic volatile organic compound emissions, Atmos. Chem. Phys., 6, 2129-2146, doi:10.5194/acp-6-2129-2006, 2006.

Lauer, A., Hendricks, J., Ackermann, I., Schell, B., Hass, H., and Metzger, S.: Simulating aerosol microphysics with the ECHAM/MADE GCM - Part 1: Model description and comparison with observations, Atmos. Chem. Phys., 5, 3251-3276, doi:10.5194/acp-5-3251-2005, 2005.

Law, R. M., Rayner, P. J., Denning, A. S., Erickson, D., Fung, I. Y., Heimann, M., Piper, S. C., Ramonet, M., Taguchi, S., Taylor, J. A., Trudinger, C. M., and Watterson, I. G.: Variations in modeled atmospheric transport of carbon dioxide and the consequences for $\mathrm{CO}_{2}$ inversions, Global Biogeochem. Cy., 10, 783-796, 1996.

Lee, D. S., Kohler, I., Grobler, E., Rohrer, F., Sausen, R., GallardoKlenner, L., Olivier, J. G. J., Dentener, F. J., and Bouwman, A. F.: Estimations of global Nox emissions and their uncertainties, Atmos. Environ., 31, 1735-1749, 1997.

Li, W. J. and Shao, L. Y.: Observation of nitrate coatings on atmospheric mineral dust particles, Atmos. Chem. Phys., 9, 18631871, doi:10.5194/acp-9-1863-2009, 2009.

Liao, H. and Seinfeld, J. H.: Global impacts of gas-phase chemistryaerosol interactions on direct radiative forcing by anthropogenic aerosols and ozone, J. Geophys. Res., 110, D18208, doi:10.1029/2005JD005907, 2005.

Liao, H., Zhang, Y., Chen, W.-T., Raes, F., and Seinfeld, J. H.: Effect of chemistry-aerosol-climate coupling on predictions of future climate and future levels of tropospheric ozone and aerosols, J. Geophys. Res., 114, D10306, doi:10.1029/2008JD010984, 2009.

Martin, S. T., Schlenker, J. C., Malinowski, A., Hung, H.M., and Rudich, Y.: Crystallization of atmospheric sulfatenitrate-ammonium particles, Geophys. Res. Lett., 30, 2102, doi:10.1029/2003GL017930, 2003.

Martin, S. T., Hung, H.-M., Park, R. J., Jacob, D. J., Spurr, R. J. D., Chance, K. V., and Chin, M.: Effects of the physical state of tropospheric ammonium-sulfate-nitrate particles on global aerosol direct radiative forcing, Atmos. Chem. Phys., 4, 183214, doi:10.5194/acp-4-183-2004, 2004.

Mensah, A. A., Holzinger, R., Otjes, R., Trimborn, A., Mentel, Th. F., ten Brink, H., Henzing, B., and Kiendler-Scharr, A.: Aerosol chemical composition at Cabauw, The Netherlands as observed in two intensive periods in May 2008 and March 2009, Atmos. Chem. Phys., 12, 4723-4742, doi:10.5194/acp-12-4723-2012, 2012.

Metzger, S., Dentener, F., Pandis, S., and Lelieveld, J.: Gas/aerosol partitioning: 1. A computationally efficient model, J. Geophys. Res., 107, 4312, doi:10.1029/2001JD001102, 2002a. 
Metzger, S., Dentener, F., Krol, M., Jeuken, A., and Lelieveld, J.: Gas/aerosol partitioning: 2. Global modeling results, J. Geophys. Res., 107, 4312, doi:10.1029/2001JD001103, 2002b.

Mozurkewich, M.: The dissociation constant of ammonium nitrate and its dependence on temperature, relative humidity and particle size, Atmos. Environ. A-Gen., 27, 261-270, 1993.

Myhre, G., Grini, A., and Metzger, S.: Modelling of nitrate and ammonium-containing aerosols in presence of sea salt, Atmos. Chem. Phys., 6, 4809-4821, doi:10.5194/acp-6-4809-2006, 2006.

Myhre, G., Samset, B. H., Schulz, M., Balkanski, Y., Bauer, S., Berntsen, T. K., Bian, H., Bellouin, N., Chin, M., Diehl, T., Easter, R. C., Feichter, J., Ghan, S. J., Hauglustaine, D., Iversen, T., Kinne, S., Kirkevåg, A., Lamarque, J.-F., Lin, G., Liu, X., Lund, M. T., Luo, G., Ma, X., van Noije, T., Penner, J. E., Rasch, P. J., Ruiz, A., Seland, Ø., Skeie, R. B., Stier, P., Takemura, T., Tsigaridis, K., Wang, P., Wang, Z., Xu, L., Yu, H., Yu, F., Yoon, J.-H., Zhang, K., Zhang, H., and Zhou, C.: Radiative forcing of the direct aerosol effect from AeroCom Phase II simulations, Atmos. Chem. Phys., 13, 18531877, doi:10.5194/acp-13-1853-2013, 2013.

Nenes, A., Pandis, S., and Pilinis, C.: ISORROPIA: a new thermodynamic equilibrium model for multiphase multicomponent inorganic aerosols, Aquat. Geochem., 4, 123-152, 1998.

Olivier, J. G. J., Bouwman, A. F., Van der Hoek, K. W., and Berdowski, J. J. M.: Global air emission inventories for anthropogenic sources of $\mathrm{NO}_{\mathrm{x}}, \mathrm{NH}_{3}$, and $\mathrm{N}_{2} \mathrm{O}$ in 1990, Environ. Pollut., 102, 135-148, 1998.

Park, R. J., Jacob, D. J., Field, B. D., Yantosca, R. M., and Chian, M.: Natural and transboundary pollution influences on sulfate-nitrate-ammonium aerosols in the United States: implications for policy, J. Geophys. Res., 109, D15204, doi:10.1029/2003JD004473, 2004.

Pilinis, C. and Seinfeld, J. H.: Continued development of a general equilibrium model for inorganic multicomponent atmospheric aerosols, Atmos. Environ., 21, 2453-2466, 1987.

Pilinis, C., Capaldo, K. P., Nenes, A., and Pandis, S. N.: MADM - a new multicomponent aerosol dynamics model, Aerosol Sci. Tech., 32, 482-502, 2000.

Pison, I., Bousquet, P., Chevallier, F., Szopa, S., and Hauglustaine, D.: Multi-species inversion of $\mathrm{CH}_{4}, \mathrm{CO}$ and $\mathrm{H}_{2}$ emissions from surface measurements, Atmos. Chem. Phys., 9, 5281-5297, doi:10.5194/acp-9-5281-2009, 2009.

Pringle, K. J., Tost, H., Message, S., Steil, B., Giannadaki, D., Nenes, A., Fountoukis, C., Stier, P., Vignati, E., and Lelieveld, J.: Description and evaluation of GMXe: a new aerosol submodel for global simulations (v1), Geosci. Model Dev., 3, 391-412, doi:10.5194/gmd-3-391-2010, 2010.

Putaud, J. P., Raes, F., Van Dingenen, R., Brüggemann, E., Facchini, M.-C., Decesari, S., Fuzzi, S., Gehrig, R., Hüglin, C., Laj, P., Lorbeer, G., Maenhaut, W., Mihalopoulos, N., Müller, K., Querol, X., Rodriguez, S., Schneider, J., Spindler, G., ten Brink, H., Tørseth, K., and Wiedensohler, A.: European aerosol phenomenology-2: chemical characteristics of particulate matter at kerbside, urban, rural and background sites in Europe, Atmos. Environ., 38, 2579-2595, 2004a.

Putaud, J.-P., Van Dingenen, R., Dell'Acqua, A., Raes, F., Matta, E., Decesari, S., Facchini, M. C., and Fuzzi, S.: Size-segregated aerosol mass closure and chemical composition in Monte $\mathrm{Ci}$ - mone (I) during MINATROC, Atmos. Chem. Phys., 4, 889-902, doi:10.5194/acp-4-889-2004, 2004b.

Reidmiller, D. R., Fiore, A. M., Jaffe, D. A., Bergmann, D., Cuvelier, C., Dentener, F. J., Duncan, B. N., Folberth, G., Gauss, M., Gong, S., Hess, P., Jonson, J. E., Keating, T., Lupu, A., Marmer, E., Park, R., Schultz, M. G., Shindell, D. T., Szopa, S., Vivanco, M. G., Wild, O., and Zuber, A.: The influence of foreign vs. North American emissions on surface ozone in the US, Atmos. Chem. Phys., 9, 5027-5042, doi:10.5194/acp-9-5027-2009, 2009.

Rivier, L., Ciais, P., Hauglustaine, D. A., Bakwin, P., Bousquet, P., Peylin, P., and Klonecki, A.: Evaluation of SF6, C2Cl4, and CO to approximate fossil fuel $\mathrm{CO}_{2}$ in the Northern Hemisphere using a chemistry transport model, J. Geophys. Res., 111, D16311, doi:10.1029/2005JD006725, 2006.

Sander, S. P., Abbatt, J., Barker, J. R., Burkholder, J. B., Friedl, R. R., Golden, D. M., Huie, R. E., Kolb, C. E., Kurylo, M. J., Moortgat, G. K., Orkin, V. L., and Wine, P. H.: Chemical Kinetics and Photochemical Data for Use in Atmospheric Studies, Evaluation No. 17, JPL Publication 10-6, Jet Propulsion Laboratory, Pasadena, 2011.

Schaap, M., van Loon, M., ten Brink, H. M., Dentener, F. J., and Builtjes, P. J. H.: Secondary inorganic aerosol simulations for Europe with special attention to nitrate, Atmos. Chem. Phys., 4, 857-874, doi:10.5194/acp-4-857-2004, 2004.

Schaap, M., Otjes, R. P., and Weijers, E. P.: Illustrating the benefit of using hourly monitoring data on secondary inorganic aerosol and its precursors for model evaluation, Atmos. Chem. Phys., 11, 11041-11053, doi:10.5194/acp-11-11041-2011, 2011.

Schulz, M.: Constraining Model Estimates of the Aerosol Radiative Forcing, Thèse d'Habilitation à Diriger des Recherches, Université Pierre et Marie Curie, Paris VI, 2007.

Schulz, M., Balkanski, Y., Dulac, F., and Guelle, W.: Role of aerosol size distribution and source location in a three-dimensional simulation of a Saharan dust episode tested against satellite-derived optical thickness, J. Geophys. Res., 103, 10579-10592, 1998.

Schulz, M., Textor, C., Kinne, S., Balkanski, Y., Bauer, S., Berntsen, T., Berglen, T., Boucher, O., Dentener, F., Guibert, S., Isaksen, I. S. A., Iversen, T., Koch, D., Kirkevåg, A., Liu, X., Montanaro, V., Myhre, G., Penner, J. E., Pitari, G., Reddy, S., Seland, $\emptyset$., Stier, P., and Takemura, T.: Radiative forcing by aerosols as derived from the AeroCom present-day and pre-industrial simulations, Atmos. Chem. Phys., 6, 5225-5246, doi:10.5194/acp-65225-2006, 2006.

Schulz M., Gauss, M., Benedictow, A., Jonson, J. E., Tsyro, S., Nyiri, A., Simpson, D., Steensen, B. M., Klein, H., Valdebenito, 5 A., Wind, P., Kirkevåg, A., Griesfeller, J., Bartnicki, J., Olivié, D., Grini, A., Iversen, T., Seland, Ø., Semeena, V. S., Fagerli, H., Aas, W., Hjellbrekke, A.-G., Mareckova, K., Wankmuller, R., Schneider, P., Solberg, S., Svendby, T., Liu, L., Posch, M., Vieno, M., Reis, S., Kryza, M., Werner, M., and Walaszek, K.: Transboundary acidification, euthropication and ground level ozone in Europe in 2011, EMEP Report 1/2013, Norwegian Meteorological Institute, ISSN 1504-6109, 2013.

Schwartz, S. E.: Mass transport considerations pertinent to aqueousphase reactions of gases in liquid-water clouds, in: Chemistry of Multiphase Atmospheric Systems, edited by: Jaeschke, W., 415471, Springer, New York, 1986. 
Seinfeld, J. H., and Pandis, S. N.: Atmospheric chemistry and Physics, John Wiley and Sons, New York, 1998.

Shindell, D. T., Lamarque, J.-F., Schulz, M., Flanner, M., Jiao, C., Chin, M., Young, P. J., Lee, Y. H., Rotstayn, L., Mahowald, N., Milly, G., Faluvegi, G., Balkanski, Y., Collins, W. J., Conley, A. J., Dalsoren, S., Easter, R., Ghan, S., Horowitz, L., Liu, X., Myhre, G., Nagashima, T., Naik, V., Rumbold, S. T., Skeie, R., Sudo, K., Szopa, S., Takemura, T., Voulgarakis, A., Yoon, J.-H., and Lo, F.: Radiative forcing in the ACCMIP historical and future climate simulations, Atmos. Chem. Phys., 13, 2939-2974, doi:10.5194/acp-13-2939-2013, 2013.

Sun, Q. and Wexler, A. S.: Modeling urban and regional aerosols near acid neutrality application to the 24-25 June SCAQS episode, Atmos. Environ., 32, 3533-3545, 1998.

Sutton, M. A., Dragosits, U., Tang, Y. S., and Fowler, D.: Ammonia emissions from non-agricultural sources in the UK, Atmos. Environ., 34, 855-869, 2000.

Szopa, S, Balkanski, Y., Schulz, M., Bekki, S., Cugnet, D., FortemsCheiney, A., Turquety, S., Cozic, A., Deandreis, C., Hauglustaine, D., Idelkadi, A., Lathiere, J., Marchand, M., Yan, N., and Dufresne, J.-L.: Aerosol and ozone changes as forcing for climate evolution between 1850 and 2100, Clim. Dynam., 40, 2223-2250, doi:10.1007/s00382-012-1408-y, 2012.

Tang, I. N.: Chemical and size effects of hygroscopic aerosols on light scattering coefficients, J. Geophys. Res., 101, 2156-2202, doi:10.1029/96JD03003, 1996.

Ten Brink, H., Otjes, R., Jongejan, P., and Slanina, S.: An instrument for semi-continuous monitoring of the size-distribution of nitrate, ammonium, sulphate and chloride in aerosol, Atmos. Environ., 41, 2768-2779, 2007.
Tie, X., Madronich, S., Walters, S., Edwards, D. P., Ginoux, P., Mahowald, N., Zhang, R. Y., Lou, C., and Brasseur, G.: Assessment of the global impact of aerosols on tropospheric oxidants, J. Geophys. Res., 110, D03204, doi:10.1029/2004JD005359, 2005.

van Dorland, R., Dentener, F. J., and Lelieveld, J.: Radiative forcing due to tropospheric ozone and sulphate aerosols, J. Geophys. Res., 102, 28079-28100, 1997.

Van Leer, B.: Towards the ultimate conservative difference scheme. Part IV: a new approach to numerical convection, J. Comput. Phys., 23, 276-299, 1977.

Wang, R., Tao, S., Wang, W., Liu, J., Shen, H., Shen, G., Wang, B., Liu, X., Li, W., Huang, Y., Zhang, Y., Lu, Y., Chen, H., Chen, Y., Wang, C., Zhu, D., Wang, X., Li, B., Liu, W., and Ma, J.: Black carbon emissions in China from 1949 to 2050, Environ. Sci. Technol., 46, 7595-7603, 2012.

$\mathrm{Xu}$, L. and Penner, J. E.: Global simulations of nitrate and ammonium aerosols and their radiative effects, Atmos. Chem. Phys., 12, 9479-9504, doi:10.5194/acp-12-9479-2012, 2012.

Zhang, L., Jacob, D. J., Knipping, E. M., Kumar, N., Munger, J. W., Carouge, C. C., van Donkelaar, A., Wang, Y. X., and Chen, D.: Nitrogen deposition to the United States: distribution, sources, and processes, Atmos. Chem. Phys. Discuss., 12, 241282, doi:10.5194/acpd-12-241-2012, 2012.

Zhang, Y., Seigneur, C., Seinfeld, J. H., Jacobson, M., Clegg, S. L., and Binkowski, F. S.: A comparative review of inorganic aerosol thermodynamic equilibrium modules: similarities, differences, and their likely causes, Atmos. Environ., 34, 117-137, 2000. 